\title{
UPDATE AND ASSESSMENT OF GEOTHERMAL ECONOMIC MODELS, GEOTHERMAL FLUID FLOW AND HEAT DISTRIBUTION MODELS, AND GEOTHERMAL DATA BASES
}

\author{
May, 1985 \\ Prepared for: \\ U.S. Department of Energy \\ Assistant Secretary Conservation and Renewable Energy
}

Geothermal and Hydropower Technologies Division

Under Contract Number: DE-AC01-83CE30784

(Meridian Project No. MC-154BG) 


\section{DISCLAIMER}

This report was prepared as an account of work sponsored by an agency of the United States Government. Neither the United States Government nor any agency Thereof, nor any of their employees, makes any warranty, express or implied, or assumes any legal liability or responsibility for the accuracy, completeness, or usefulness of any information, apparatus, product, or process disclosed, or represents that its use would not infringe privately owned rights. Reference herein to any specific commercial product, process, or service by trade name, trademark, manufacturer, or otherwise does not necessarily constitute or imply its endorsement, recommendation, or favoring by the United States Government or any agency thereof. The views and opinions of authors expressed herein do not necessarily state or reflect those of the United States Government or any agency thereof. 


\section{DISCLAIMER}

Portions of this document may be illegible in electronic image products. Images are produced from the best available original document. 


\section{DISCLAIMER}

This report was prepared as an account of work sponsored by an agency of the United States Government. Neither the United States Government nor any agency thereof, nor any of their employees, makes any warranty, express or implied, or assumes any legal liability or responsibility for the accuracy, completeness, or usefulness of any information, apparatus, product, or process disclosed, or represents that its use would not infringe privately owned rights. Reference herein to any specific commercial product, process, or service by trade name, trademark, manufacturer, or otherwise does not necessarily constitute or imply its endorsement, recommendation, or favoring by the United States Government or any agency thereof. The views and opinions of authors expressed herein do not necessarily state or reflect those of the United States Government or any agency thereof.

This report has been reproduced directly from the best available copy.

Available from the National Technical Information Service, U. S. Department of Commerce, Springfield, Virginia 22161.

Price: Printed Copy A06

Microfiche A01

Codes are used for pricing all publications. The code is determined by the number of pages in the publication. Information pertaining to the pricing codes can be found in the current issues of the following publications, which are generally available in most libraries: Energy Research Abstracts (ERA); Government Reports Announcements and Index (GRA and I); Scientific and Technical Abstract Reports (STAR); and publication NTIS-PR-360 available from NTIS at the above address. 


\title{
UPDATE AND ASSESSMENT OF GEOTHERMAL ECONOMIC MODELS, GEOTHERMAL FLUID FLOW AND HEAT DISTRIBUTION MODELS, AND GEOTHERMAL DATA BASES
}

\author{
May, 1985 \\ Prepared for: \\ U.S. Department of Energy \\ Assistant Secretary Conservation and Renewable Energy \\ Geothermal and Hydropower Technologies Division \\ Washington, D.C. 20585
}

Under Contract Number: DE-ACO1-83CE30784

(Meridian Project No. MC-154BG)

Prepared by:

Meridian Corporation

5113 Leesburg Pike, Suite 700

Falls Church, Virginia 22041

Edited By: D. Kenkeremath 
Numerical simulation models and data bases that were developed for DOE as part of a number of geothermal programs have been assessed with respect to their overall stage of development and usefulness. This report combines three separate studies that focus attention upon: 1) economic models related to geothermal energy; 2) physical geothermal system models pertaining to thermal energy and the fluid medium; and 3) geothermal energy data bases.

Computerized numerical models pertaining to the economics of extracting and utilizing geothermal energy have been summarized and catalogued with respect to their availability, utility and function. The 19 models that are discussed in detail were developed for use by geothermal operators, public utilities, and lending institutions who require a means to estimate the value of a given resource, total project costs, and the sensitivity of these values to specific variables. A number of the models are capable of economically assessing engineering aspects of geothermal projects.

Computerized simulations of heat distribution and fluid flow have been assessed and are presented for ten models. Five of the models are identified as wellbore.simulators and five are described as reservolr simulators. Each model is described in terms of its operational characteristics, input, output, and other pertinent attributes.

Geothermal energy data bases are reviewed with respect to their current usefulness and availability. Summaries of elght data bases are provided in catalogue format, and an overall comparison of the elements of each data base is included. 
CONTENTS

Page

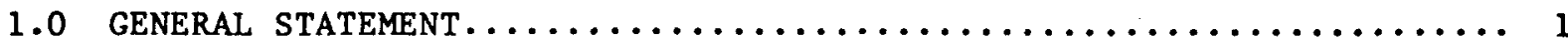

2.0 ASSESSMENT OF GEOTHERMAL ECONOMIC MODELS

By James $v$. Satrape............................. 3

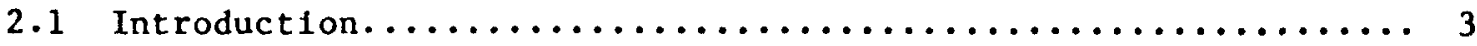

2.2 General Discussion of the Models.................... 4

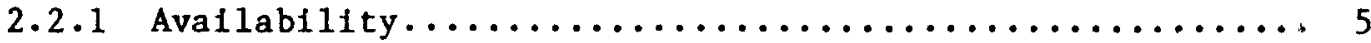

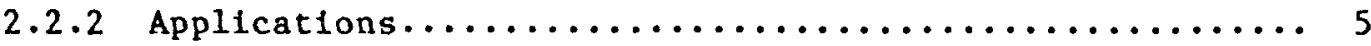

2.2.3 Internal Features......................... 9

2.3 Model Descriptions.............................. 16

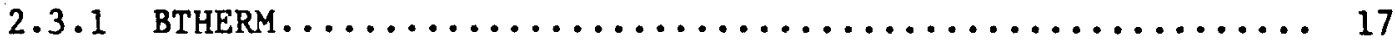

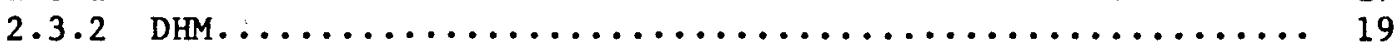

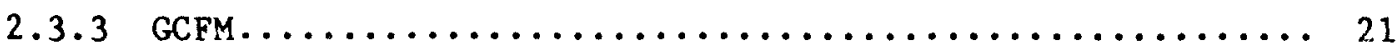

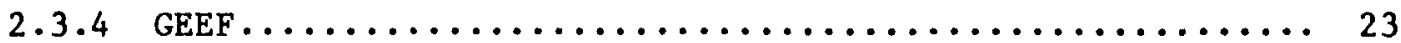

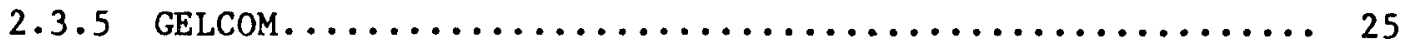

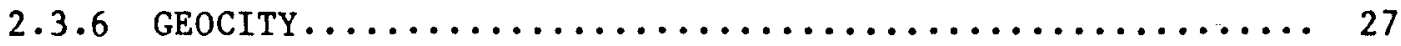

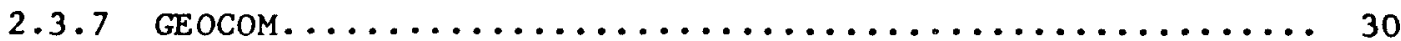

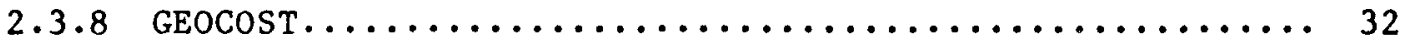

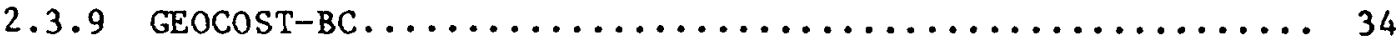

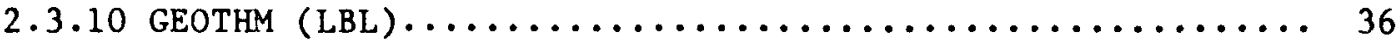

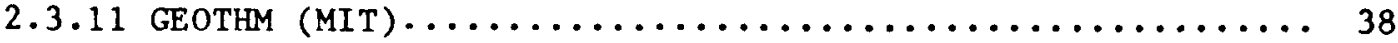

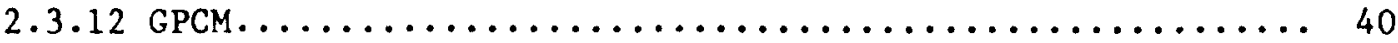

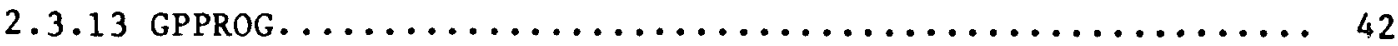

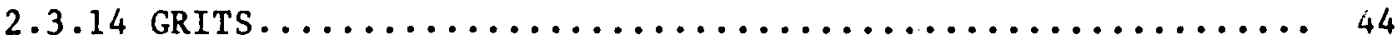

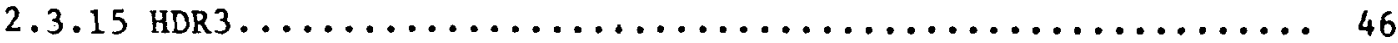

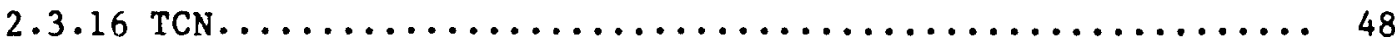

2.3 .17 Texas Geopressured....................... 50

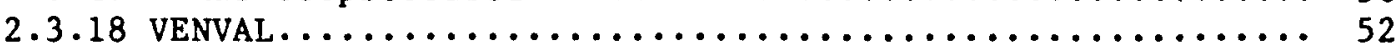

2.3 .19 WELCST...................................... 54

2.4 Other Models............................... 55

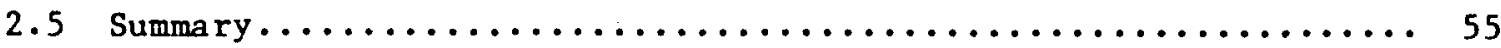

2.6 References................................. 56

3.0 COMPUTER MODELS OF GEOTHERMAL HEAT AND FLUID FLOW

By Richard McKenna........................... 57

3.1 Introduction. $\ldots \ldots \ldots \ldots \ldots \ldots \ldots \ldots \ldots \ldots \ldots \ldots \ldots \ldots \ldots \ldots$

3.2 Comparative Discussion......................... 58

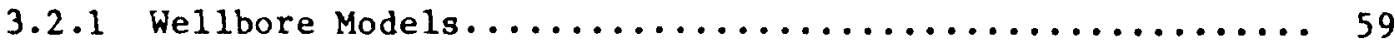

3.2 .2 Reservolr Models............................ 64

3.3 Model Descriptions............................ 66

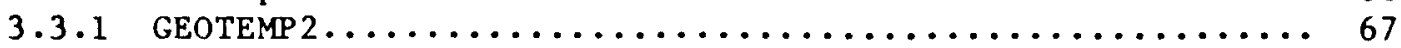

3.3.2 Interactive Fracture Design Model............... 70 


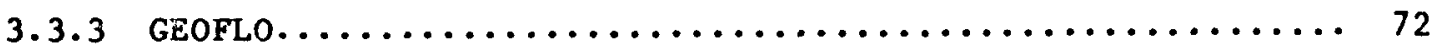

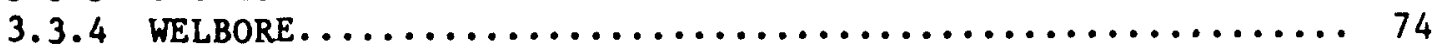

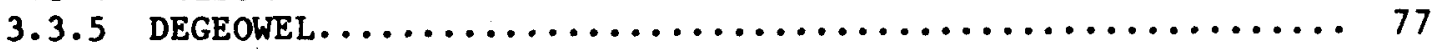

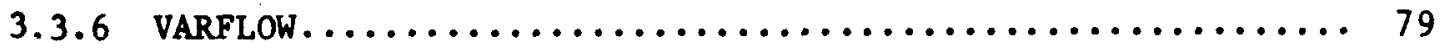

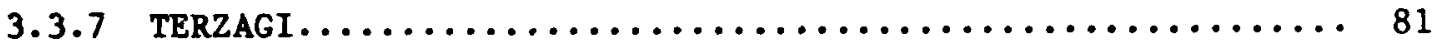

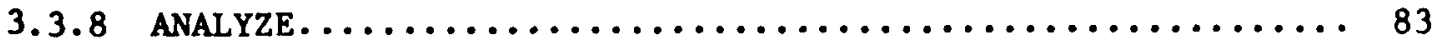

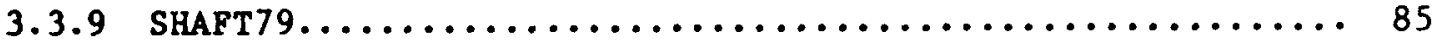

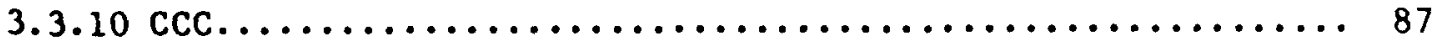

3.4 References.................................... 89

3.5 Annotated Bibllography.......................... 89

\subsection{ASSESSMENT OF GEOTHERMAL RELATED DATA BASES}

By Robert E. Blacket........................... 92

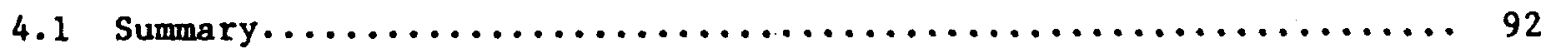

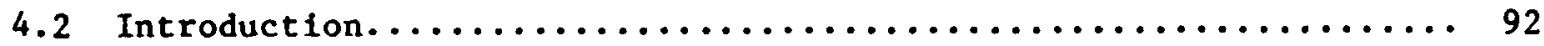

4.3 Data Base Comparison........................... 94

4.4 Data Base Descriptions........................... 100

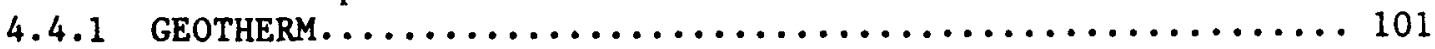

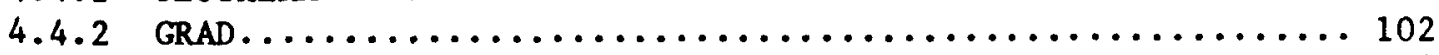

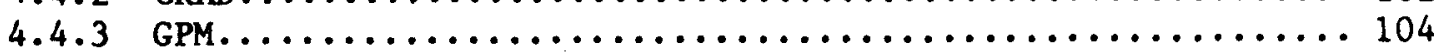

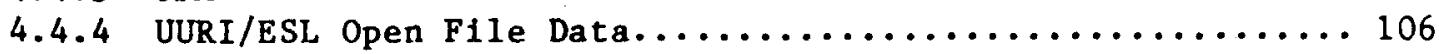

4.4 .5 UURI/ESL Geothermal Sample Library................ 108

4.4 .6 OIT Site Data Base Reports..................... 110

4.4.7 Geothermal Leasing and Permitting Data Base........... 112

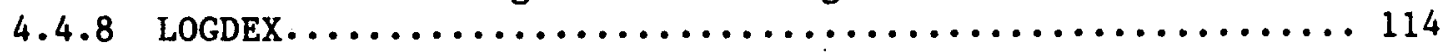




\section{LIST OF TABLES}

TABLE

1: $\quad$ LIST OF ECONOMIC MODELS $\ldots \ldots \ldots \ldots \ldots \ldots \ldots \ldots \ldots \ldots \ldots \ldots \ldots \ldots$

2: $\quad$ ECONOMIC MODEL DESCRIPTIONS $\ldots \ldots \ldots \ldots \ldots \ldots \ldots \ldots \ldots \ldots \ldots \ldots$

3: SUMMARY OF KEY ECONOMIC MODEL DESCRIPTIONS............. 10

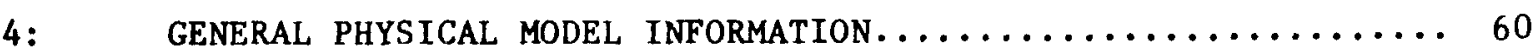

5: $\quad$ PHYS ICAL MODEL CHARACTERISTICS $\ldots \ldots \ldots \ldots \ldots \ldots \ldots \ldots \ldots \ldots \ldots \ldots \ldots \ldots$

6: GENERALIZED DATA BASE COMPARISON................... 95 
In September 1974, the President signed into law Public Law 93-410. The "Geothermal Energy Research and Demonstration Act of 1974" was an act that established a geothermal management program on a federal level to provide for continuing research and development of geothermal resources in the United States. During the following years, the U.S. Department of Energy (DOE) and its predcessor agency sponsored many research and development projects that would increase the quantity of technical data and Improve methodologies to assess and develop geothermal energy resources in the United States. A substantial effort was directed towards developing analytical methods and data to assist the geothermal industry. This included computerized models of physical processes in geothermal energy extraction and conversion, as we11 as computerized economic models. A separate emphasis was also placed upon collecting basic data necessary for the ultimate commercialization of geothermal energy.

The purpose of this report is to serve as a catalogue and to assess the many models and data bases that have been developed with DOE funding. It is hoped that the information presented here will provide interested persons and organizations with knowledge of the location, avallability, and application of pertinent geothermal models and data bases.

DOE program participants have included private contractors, national labs, and universities whose work has collectively resulted in the development of the many models and data bases presented herein.

The following report is separated into three chapters that describe the usefulness, avallability and applicability of: (1) economic models; (2) heat distribution and fluid flow models; and (3) data bases related to geothermal energy development.

Section 2 presents a general discussion of the characteristics of economic models for geothermal energy utilization, compares the models in a tabular 
fashion, and provides a detafled summary of input/output parameters, avallability, references, key words, etc., for 19 models.

Section 3 provides a comparison and catalogue of computer models of geothermal heat and fluid flow. Models assessed were limited to wellbore and reservolr models that deal with the simulation of fluid and/or thermal flux through geothermal systems.

Section 4 presents a catalogue and comparison of DOE sponsored geothermal related data bases. The data bases are described with regard to their content, current avallability, general purpose, and other pertinent factors. 
2.0 ASSESSMENT OF GEOTHERMAL ECONOMIC RELATED MODELS

by James V. Satrape

\subsection{Introduction}

Throughout the 1ate 1970's and early 1980's, the U.S. Department of Energy sponsored a number of analytical studies with the goals of quantifying, in one sense or another, the costs assoclated with exploiting geothermal energy resources. Many computer models wefe developed to perform these calculations. In some cases, the codes were written to assist in the analysis pertaining to a specific study; in other cases, the computer programs themselves were the end result of the research effort.

Outside the small group of people who were involved with the development of the Individual models, and in a few instances the users, the capabilities of the models and where they can be obtained is no longer well known. In some cases they may be sitting on shelves waiting to be used. In others, the work had been terminated by funding cutbacks before the computer programs could be documented for the average user.

The purpose of this study is to assess the current status of geothermal energy cost analysis software. This paper provides a general discussion of the applicability and characteristics of the models, followed by a brief abstract for each model. Since the programs described here were funded by the federal government, they are (In theory) avallable to the public.

In general, a computer model is written with a specific application in mind. In the case of geothermal economic models, this application might be calculations of cost optimlzation, year by year cash flow simulation, or market penetration studies. Each of these general applications entalls a separate methodology in Its assumptions and calculations and is targeted to a specific user group.

Parallel to the intended application of the model is the sector of the geothermal community having need for the program. Englneers and A\&E firms can 
use engineering design and optimization programs to verify their calculations or to visualize the Impacts of certaln changes on overall cost or efficiency. Developers and utflities need measures of value and total cost for a given project, with some indication of the sensitivity to certain parameters or the amount of risk involved. Financial institutions, insurance companies, and government loan guarantee officers require a cash flow profile as well as some measure of sensitivity in order to make their decisions. Department of Energy program managers need to know the critical areas of research which, if properly funded, w11 provide the maximum benefit in lmproving the economics of geothermal energy. Other state, federal and local public officlals may have a desire to define localities where there is a potential for the development of a geothermal resource.

Individual models are also written to address particular engineering aspects of geothermal development. They may consider for example, well costs, fluid distribution systems, either direct use or electric production, or any subsets and combinations of these.

\subsection{General Discussion of the Models}

The general characteristics of the models are described in Tables 1 through 3 . Table 1 provides the model name and commonly used mnemonic (e.g. BTHERM), where and when the mode1 was developed, and an indication of the current avallabllity of the mode1. Table 2 lists the type of geothermal resource evaluated by the model, the types of energy end uses analyzed, and the type of financial analysis or pollcy analysis for which the model was developed. Table 3 describes the major technical approaches and necess ry parameter Inputs used in each model.

The remaining text in this section defines and describes the major column headings in the tables. In noteworthy cases, major differences and simllaritles among the models are highlighted. 


\subsubsection{Availability}

Table 1 lists the models described in this paper, their institution, and year of origin.

The last column in Table 1 describes the avallability of each model. Ease of access to the model code and documentation is a very important consideration for anyone planning to use these models.

The avallability of the various models is given on a scale of 0 to 5 , as follows :

0: Unavailable.

1: Model has 11mited avallabllity (DOE or contractors) because of proprietary nature.

2: Computer code is avallable, but without sufficient documentation or assistance. It would require considerable work to implement the program.

3: Program listing is avallable, wth documentation. The user may have to enter the program by hand.

4: Similar to 3, plus the fact that assistance may be avallable from one or more of the authors, or the developers of the model may be contracted to perform a given study.

5: Program, (tape or cards), listing, and documentation are avallable "off the shelf." Documentation is adequate to allow fairly rapid startup for a new user.

\subsubsection{Applications}

Table 2 describes each mode1 with respect to the physical and financial situations which the model was designed to analyze or describe. The main differences among the models lie in their coverage of different types of geothermal resources, energy end use systems, and financlal analysis.

Geotherma1 Resource

Models are Included in this study for hydrothermal, hot dry rock, and geopressured resources. The majority of them, as seen in Table 2, are written to evaluate hydrothermal resources. Both high and moderate temperature geothermal reservolis are represented. 
Model Name

BTHERM (D18trict Heating Cost)

DHM: D1strict Beat1ag Model

GCFM: Geotheral Loan Guaranty Cash Flow Model

GEEF : Geothermal Englneering and Economic Peasibility Model

GRLCOM: Geothermal Levellzed Busbar Cost Model

GEOCITY: Geothermal D1strict Heating Cost Analysia

GEOCOM: Geothermal Completion Technology Life-Cycle Cost Model

GEOCOST: Geothermal Cost Analysis - steam Cycle Version

GEOCOST-BC: Geothermal Cost Analys1s - Blnary Cycle Version

GEOTHM: Geothermal Thermodynamic and Cost Optinization Model

SROTHY: (Process Heat Design)

GPCM: Geothermal Probabilistic Cost Model

GPPROG: (Geopressured)

GRITS: Geothermal Resource Interactive Temporal Simulation

HDR3 (Hot Dry Rock District Heating)

TCN: Geotherwal Investoent and Policy Analysis

Texas Geopressured Resource Evaluation

VENVAL: (Venture Analys 18)

WELCST: Geothermal Well CoBt Model
Where Developed

New Mexico Energy Institute

Brookhaven National Laboratory

MITRE Corporation

Engineeriag and Economics

Research

MTRE Corporation

Battelle-Paciflc Northwest

Laboratories

The BDM Corporation

Battelle-Pacific Northwest

Laboratories

Battelle-Pac1fic Northuest

Laboratories

Larrence Berkeley Laboratory

Massachusetts Institute of Technology

Jet Propulaton Laboratory

Loulslana State Unfversity

John's Hopkins UnIveraity/

Applled Physics Leboratory

Los Alamos Nat1onal Laboratory

Technecon Analyt1c Regearch

Unfversity of Texas at Austio

Dupont de Nemours, Inc.

Mtre Corporation
Year Avallab1l1ty

1980 ?

$1980 \quad 3$

$1982 \quad 5$

$1981 \quad 2$

$1978 \quad 2$

$1978 \quad 5$

19824

1982

$1975 \quad 5$

19812

$1976 \quad 5$

$1981 \quad 2$

$1977 ?$

$1980 \quad 3$

$1981 ?$

$1979 ?$

19824

$1982 \quad 3$

19813

$1979 ?$

$1980 \quad 1$

19793

* For explanation, see tert, page 5.

Table 1: List of Economic ifodels 


\begin{tabular}{|c|c|c|c|}
\hline Hodel & Geotherasl Resource & End Vae & Type of Analyais \\
\hline BTEERY & Hydrotherail & $\begin{array}{l}\text { District Heat1as, Procese Heat, } \\
\text { Space Heating }\end{array}$ & Cost/Benefit \\
\hline DEM & Hyd rotherael & District Heating : & $\begin{array}{l}\text { Cost/Benef } 1 t \text {, Market } \\
\text { Penetration }\end{array}$ \\
\hline GCFM & Hydrothermal & Electricity Production & $\begin{array}{l}\text { Cost/Benef } 1 t, \text { Rlsk } \\
\text { Assessment }\end{array}$ \\
\hline GEEP & Hydrotheranl & Process Heat & Cost/Benef It \\
\hline GELCOM & Hydrotherael & Electricity Production & Cont/Benef 1t \\
\hline GEOCITY & Hydrothermal & District Beating/Cooling & Cost/Benef 1t, Design \\
\hline GEOCOM & Hydrothermal & None & $\begin{array}{l}\text { Cost/Benef1t, RaD } \\
\text { Planning }\end{array}$ \\
\hline GEOCOST & Hydrothermal & Electriclty Production & Cost/Benef 1t, Design \\
\hline GEOCOST-BC & Hydrothermal & Electriclty Production & Cost/Benef 1t, Des1gn \\
\hline GEOTHY (LBL) & Bydrothermal & Electricity Production & Des1gn \\
\hline GEOTHA (MIT) & Hydrothermal & Process Heat & Cost/Benef It, Design \\
\hline GPCM & Hydrothe raal & None & $\begin{array}{l}\text { Cost/Benef } 1 t, \text { Risk } \\
\text { Assessaent }\end{array}$ \\
\hline GPPROG & Geopressured & Wethane Production & $\begin{array}{l}\text { Cost/Benef1t, R1sk } \\
\text { Assessment, Market } \\
\text { Penetrat1on }\end{array}$ \\
\hline GRITS & Hydrothermal & $\begin{array}{l}\text { District Heating, Process Beat, } \\
\text { Space Heating }\end{array}$ & Cost/Benef1t \\
\hline HDR3 & Hot Dry Rock & Space Heat1ag & Cost/Benef1t \\
\hline TCN & Bydrotherwal & Electricity Production & $\begin{array}{l}\text { R1sk Assessment, } \\
\text { Market Penetration }\end{array}$ \\
\hline Un1v. of TX & Geopressured & Wethane Production & $\begin{array}{l}\text { Cost/Benef } 1 t, \text { Market } \\
\text { Penetration }\end{array}$ \\
\hline VENVAL. & $\mathbf{N} / \mathbf{A}$ & $N / A$ & $\begin{array}{l}\text { Cost/Benefit, RIsk } \\
\text { Assessaent }\end{array}$ \\
\hline WELCST & Hydrotherael & None & $\begin{array}{l}\text { Cost/Benef1t, BSD } \\
\text { Planning }\end{array}$ \\
\hline
\end{tabular}

Table 2: Economic ifodel Jescriptions 
End Use

The end use of the model is defined here as the primary energy output consldered by each. This includes district heating (geothermal space and hot water heating for cities, towns, or subdivisions), space heat (small scale applications of geothermal heating), process heat (Industrial use), and electricity production. Those models Indicating no end use do not consider energy conversion but focus on elther drilling costs or field development.

\section{Type of Analysts}

This Information summarizes the most valuable applications for each program.

A cost-benefit study may be used to perform a numerical evaluation of the possible profitability of a given investment. This is applicable to feasibility studies and could be used by developers, ut 11 ties, private firms, local governments, or anyone considering investment in a geothermal project.

An assessment of risk can be determined from those models which incorporate probability distribution functions or from those which permit the performance of sensitivity analysis on key unknowns. This risk assessment is valuable to any Investor, but would be of greatest 1nterest to ut111t1es, loan Institutions, Insurance companies, and those Involved in loan guarantee programs.

The computer programs which can perform system design based on engineering relationships are useful for initial design studies and preliminary cost estimates. They can concelvably save much time in calculations when numerous designs are to be examined in a quick assessment of alternatives. They do not obviate the need for detalled analysis of the final designs.

Market penetration studies incorporate resource and geographical data bases to predict locations where geothermal energy development may be feasible. These studles could be used by government planners (at local, state, or federal levels) or by developers and firms in search of possible markets. The TCN mode1 places emphasis on a different aspect of market penetration. Based on 
extensive surveys of developers and utility decision-makers, it determines the likelihood of investment in a given project defined by a probabilistic financlal summary .

The R\&D planning models are primarily very detalled cost models which allow varlations in Individual parameters to gauge the overall effects which technologlcal Improvements may have on the economic plcture for geothermal development. These models are primarily targeted for DOE program managers or industry R\&D planners in order to maximlze the value of research funding.

\subsubsection{Internal Features}

Table 3 compares many of the major internal features of the models. For example, what one model requires as input another might calculate from different physical parameters. This 18 indicated where appropriate. The various major factors incorporated Into each model are also listed.

\section{Reservolr Modeling}

The majority of the models (Indicated by a "YES" in the second column of Table 3) model the geothermal reservolr as an Infinite, homogenous system, at a given temperature and depth, which is capable of sustaining a given flow rate per well. The HDR3 model contains a factor for reservolr temperature decay, and three of the hydrothermal models (GRITS, GEOCOM, and GPCM) contaln options for modeling reservolr flow rate degradation. The geopressured models both consider a finite, methane saturated horizon and include defining such parameters as area, thickness, porosity, etc.

In analyzing potential hydrothermal resources, it is probably unnecessary to consider reservolr decline in a preliminary feasibility study. However, it is valuable in the performance of sensitivity analyses which may help to quantify the economic risk lnvolved in a given project.

A number of the models include, in the computer program f1les, data bases 


\begin{tabular}{|c|c|c|c|c|c|c|c|}
\hline MODEL & $\begin{array}{l}\text { RESERVOIR } \\
\text { MODELING } \\
\end{array}$ & WELL COSTING & $\begin{array}{r}\text { FIELD DEVELOPMENT } \\
\text { AND PRODUCTION } \\
\end{array}$ & ENERGI CONVERSION & $\begin{array}{l}\text { FINANCIAL } \\
\text { ANALYSIS } \\
\end{array}$ & OUTPUT & MISCEZLANEOUS \\
\hline BTHERM & Yes & Input & $\begin{array}{l}\text { Exploration, succese } \\
\text { ratio, injection, } \\
\text { ayatea expansion }\end{array}$ & $\begin{array}{l}\text { Calculates heats de- } \\
\text { mand, Systen cos } 1 \mathrm{ng}, \\
\text { aysten expansion } \\
\text { retrof } 1 \mathrm{t}, \text { OdM }\end{array}$ & $\begin{array}{l}\text { Life-cycle } \\
\text { costing } \\
\text { taxes, debt, } \\
\text { eacalation }\end{array}$ & $\begin{array}{l}\text { Total cost } \\
\text { Levelized } \\
\text { energy } \\
\text { cost }\end{array}$ & \\
\hline DEMA & $\begin{array}{l}\text { Yes, } \\
\text { Resource } \\
\text { data base }\end{array}$ & $\begin{array}{l}\text { f (depth, } \\
\text { hardness) }\end{array}$ & frells based on need & $\begin{array}{l}\text { Opt Ionsl supplemen- } \\
\text { tary heat Ing, retro- } \\
\text { flt, ocM, phased con- } \\
\text { struct lon. Calcu- } \\
\text { latea heat demand. } \\
\text { opt Imization }\end{array}$ & $\begin{array}{l}\text { Life-cycle } \\
\text { coeting } \\
\text { taxes }\end{array}$ & $\begin{array}{l}\text { Leve 11zed } \\
\text { energy } \\
\text { coet }\end{array}$ & $\begin{array}{l}\text { Census and } \\
\text { county data } \\
\text { bases }\end{array}$ \\
\hline GCFA & Yea & $\begin{array}{l}\text { f (depth } \\
\text { hardness) }\end{array}$ & $\begin{array}{l}\text { Succes ratio, } \\
\text { Injection, downhole } \\
\text { pumps, weil life, } \\
\text { costs based on } \\
\text { GELCOM }\end{array}$ & $\begin{array}{l}\text { Dry or flashed oteam } \\
\text { binary, costing based } \\
\text { on GEOCOST, OSM, } \\
\text { capital replacement }\end{array}$ & $\begin{array}{l}\text { Life-cycle } \\
\text { costing, } \\
\text { tarea,debt, } \\
\text { eocalation }\end{array}$ & $\begin{array}{l}\text { Levellzed } \\
\text { energy } \\
\text { cost, } \\
\text { Cash flow }\end{array}$ & $\begin{array}{l}\text { Sensitivity } \\
\text { analysis }\end{array}$ \\
\hline GEEF & Yes & $\begin{array}{l}\text { f (depth } \\
\text { hardness) }\end{array}$ & $\begin{array}{l}\text { Exploration, well } \\
\text { life }\end{array}$ & $\begin{array}{l}\text { Direct use. User } \\
\text { deflnes heat require- } \\
\text { ments. Opt lonal } \\
\text { supplementary heat. } \\
\text { sizes and costs ays- } \\
\text { tem. OsM, capital } \\
\text { replacement. }\end{array}$ & $\begin{array}{l}\text { Life-cycle } \\
\text { costing, } \\
\text { taxes, } \\
\text { eacalation, } \\
\text { debt }\end{array}$ & $\begin{array}{l}\text { Levelized } \\
\text { energy } \\
\text { cost. } \\
\text { NPV, Cash } \\
\text { flow } \\
\text { Payback } \\
\text { perlod }\end{array}$ & \\
\hline GELCOM & $\begin{array}{l}\text { Yes, } \\
\text { Resource } \\
\text { data base }\end{array}$ & $\begin{array}{l}\text { f (depth } \\
\text { harduess) }\end{array}$ & $\begin{array}{l}\text { Injection, brine } \\
\text { treatnent, well life }\end{array}$ & $\begin{array}{l}\text { Flashed stean, bi- } \\
\text { nary: Plant ize } \\
\text { flied: Sorwe }\end{array}$ & $\begin{array}{l}\text { Life-cycle } \\
\text { costing, } \\
\text { taxes,debt, } \\
\text { escalation }\end{array}$ & $\begin{array}{l}\text { Levelized } \\
\text { busbar } \\
\text { cost }\end{array}$ & \\
\hline GEOCITY & Yes & $\begin{array}{l}\text { f (depth } \\
\text { hardness } \\
\text { tempera- } \\
\text { ture, we11 } \\
\text { des Ign) }\end{array}$ & $\begin{array}{l}\text { Exploration, success } \\
\text { ratio, injection, } \\
\text { well life, downole } \\
\text { pumps }\end{array}$ & $\begin{array}{l}\text { Direct use. Designe } \\
\text { d1stribution aystem. } \\
\text { Calculates demand. } \\
\text { OSM, cap1tal replace- } \\
\text { want, opt1mizat on } \\
\text { optional supplement- } \\
\text { ary heat. }\end{array}$ & $\begin{array}{l}\text { Life-cycle } \\
\text { costing, } \\
\text { taxes, } \\
\text { debt, } \\
\text { escalation }\end{array}$ & $\begin{array}{l}\text { Levelized } \\
\text { energy } \\
\text { cost } \\
\text { (producer } \\
\text { and } \\
\text { diatribu- } \\
\text { tor) }\end{array}$ & Steam tables \\
\hline GEOCOM & $\begin{array}{l}\text { Yes } \\
\text { Reservolr } \\
\text { decline, } \\
\text { Resource } \\
\text { data base }\end{array}$ & $\begin{array}{l}\text { Cost data } \\
\text { base. Life } \\
\text { tlae OsM d } \\
\text { modeling in- } \\
\text { cluding work- } \\
\text { overs. }\end{array}$ & $\begin{array}{l}\text { Single vell (1njec- } \\
\text { tion or production) } \\
\text { downole pumps, } \\
\text { brine treatment }\end{array}$ & $\mathbf{N} / \mathbf{A}$ & $\begin{array}{l}\text { Life-cycle } \\
\text { costing }\end{array}$ & NPV & \\
\hline GBOCOST & Yes & $\begin{array}{l}\text { f (depth } \\
\text { hardness, } \\
\text { tempera- } \\
\text { ture, we } 11 \\
\text { design }\end{array}$ & $\begin{array}{l}\text { Exploration, ouccese } \\
\text { ratio, Injection, } \\
\text { well iffe, downole } \\
\text { pumps }\end{array}$ & $\begin{array}{l}\text { Dry or flashed steam. } \\
\text { Component sizing and } \\
\text { costing. OsM, cap1- } \\
\text { tal replacements. }\end{array}$ & $\begin{array}{l}\text { Life-cycle } \\
\text { cost1ng, } \\
\text { taxes, } \\
\text { debt, } \\
\text { eacalation }\end{array}$ & $\begin{array}{l}\text { Levelized } \\
\text { energy } \\
\text { cost } \\
\text { (producer } \\
\text { and } \\
\text { ut111ty) }\end{array}$ & Steam tables \\
\hline $\begin{array}{l}\text { GEOCOST- } \\
\text { BC }\end{array}$ & Yes & $\begin{array}{l}\text { f (depth } \\
\text { hardness, } \\
\text { tempera- } \\
\text { ture, we } 11 \\
\text { design) }\end{array}$ & $\begin{array}{l}\text { Exploration, success } \\
\text { ratio, Injection, } \\
\text { we } 11 \text { iffe, downhole } \\
\text { pumps }\end{array}$ & $\begin{array}{l}\text { Binary. Component } \\
\text { sizing and costing. } \\
\text { osM, capltal replace- } \\
\text { ments. }\end{array}$ & $\begin{array}{l}\text { Life-cycle } \\
\text { coating, } \\
\text { taxes, } \\
\text { debt, } \\
\text { escalation }\end{array}$ & $\begin{array}{l}\text { Levellzed } \\
\text { energy } \\
\text { cost } \\
\text { (producer } \\
\text { and } \\
\text { ut } 111 \text { ty) } \\
\end{array}$ & Stean tables \\
\hline $\begin{array}{l}\text { GEOTEM } \\
\text { (LBL) }\end{array}$ & Yes & Input & $\begin{array}{l}\text { Injection, downole } \\
\text { pumpe }\end{array}$ & $\begin{array}{l}\text { Flashed otean, } \\
\text { blasy. Syaten de- } \\
\text { sign optimlzed for } \\
\text { user selected objec- } \\
\text { tive function. Costs } \\
\text { based on EPRI study } \\
\text { of Heber. }\end{array}$ & $\mathbf{N} / \mathbf{A}$ & $\begin{array}{l}\text { One tlme } \\
\text { cost }\end{array}$ & \\
\hline
\end{tabular}

Table 3: Summary of Key Economic Descriptors 


\begin{tabular}{|c|c|c|c|c|c|c|c|}
\hline MODEL & $\begin{array}{l}\text { RESERVOIR } \\
\text { MODELING } \\
\end{array}$ & WELL COSTING & $\begin{array}{l}\text { FIBLD DEVELOPIDNI } \\
\text { AND BEODUCTION }\end{array}$ & ENBRGY CONVERsIOA & $\begin{array}{l}\text { PINANCLAL } \\
\text { ANAIYSIS } \\
\end{array}$ & OUTPUT & HISCELLANEOUS \\
\hline $\begin{array}{l}\text { GEOTHM } \\
\text { (MIT) }\end{array}$ & Yes & Input & $\begin{array}{l}\text { Succese rat1o, wil } \\
\text { replacent }\end{array}$ & 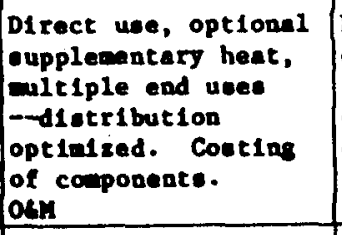 & $\begin{array}{l}\text { Life-cycle } \\
\text { costing, } \\
\text { taxes, } \\
\text { eecalietion, } \\
\text { debt }\end{array}$ & $\begin{array}{l}\text { NPV, IRR, } \\
\text { Payback } \\
\text { period }\end{array}$ & \\
\hline GPCK & $\begin{array}{l}\text { Yee, } \\
\text { Reservo1r } \\
\text { decline }\end{array}$ & Input & $\begin{array}{l}\text { Exploration, injec- } \\
\text { tion, w11 iffe, } \\
\text { pdf': }\end{array}$ & $\begin{array}{l}\text { Hot lncluded. Ueer } \\
\text { ny deflne relut1on- } \\
\text { ohipe to nodel con- } \\
\text { vereion. }\end{array}$ & $\begin{array}{l}\text { Life-cycle } \\
\text { costlag, } \\
\text { taxes, debt, } \\
\text { eacelation }\end{array}$ & $\begin{array}{l}\text { NPV } \\
\text { Level1zed } \\
\text { energy } \\
\text { cost }\end{array}$ & $\begin{array}{l}\text { Probabiliotic. } \\
\text { User nay define } \\
\text { other relation- } \\
\text { ghipg. }\end{array}$ \\
\hline GPPROG & $\begin{array}{l}\text { Tes, } \\
\text { Plnite } \\
\text { aquifier }\end{array}$ & Coat data base & $\begin{array}{l}\text { I production, } 2 \text { in- } \\
\text { jection welle, osm }\end{array}$ & $\begin{array}{l}\text { Water-methane separa- } \\
\text { tor, OSH }\end{array}$ & $\begin{array}{l}\text { tife-cycle } \\
\text { costing, } \\
\text { tarea, } \\
\text { eecalation }\end{array}$ & $\begin{array}{l}\text { NPV, IRR, } \\
\text { Optional } \\
\text { opt1miza- } \\
\text { c1on }\end{array}$ & $\begin{array}{l}\text { Study period } \\
1985-2004 \\
\text { Probab1118tic. }\end{array}$ \\
\hline GRITS & $\begin{array}{l}\text { Yea, } \\
\text { Drawdown } \\
\text { wodeled, } \\
\text { Optional } \\
\text { reservoir } \\
\text { decline } \\
\end{array}$ & f (depth) & $\begin{array}{l}\text { Exploration, eingle } \\
\text { or mitiple welle, } \\
\text { dowhole pupe, 1n- } \\
\text { jection }\end{array}$ & 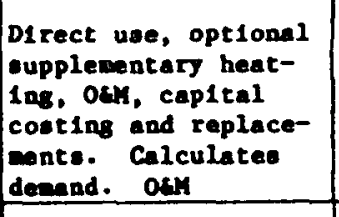 & $\begin{array}{l}\text { Life-cycle } \\
\text { costing, } \\
\text { taxes, } \\
\text { escalation, } \\
\text { debt }\end{array}$ & $\begin{array}{l}\text { NPV, } \\
\text { Payback } \\
\text { per1od, } \\
\text { Level1zed } \\
\text { energy } \\
\text { cost }\end{array}$ & $\begin{array}{l}\text { Optional Monte } \\
\text { Carlo Imulation }\end{array}$ \\
\hline $\operatorname{EDR} 3$ & $\begin{array}{l}\text { Yes, } \\
\text { Temperature } \\
\text { decline }\end{array}$ & $\begin{array}{l}\text { Optlons: } \\
\text { f (depth } \\
\text { hardaess) } \\
\text { or coat data } \\
\text { base }\end{array}$ & $\begin{array}{l}\text { S1agle production } \\
\text { and Injection } \\
\text { oyaten. Opelnized } \\
\text { (NPV) redrilling } \\
\text { progran. }\end{array}$ & $\begin{array}{l}\text { Defined by heat re- } \\
\text { quiremente, no. } \\
\text { cooting }\end{array}$ & $\begin{array}{l}\text { Life-cycle } \\
\text { coeting, } \\
\text { eecalation }\end{array}$ & NPV & $\begin{array}{l}\text { Senglt } 1 \text { ity } \\
\text { enalys }\end{array}$ \\
\hline TCN & $\begin{array}{l}\text { Yea, } \\
\text { Size of re- } \\
\text { servolr may } \\
\text { be def ined } \\
\text { as a con- } \\
\text { otant or a } \\
\text { pdf. }\end{array}$ & $\begin{array}{l}\text { (depth } \\
\text { hardnees) } \\
\text { pdf }\end{array}$ & $\begin{array}{l}\text { Rxploretion, well } \\
\text { 11fe, eucces ratlo, } \\
\text { pdf }\end{array}$ & $\begin{array}{l}\text { Pleshed atean, bi- } \\
\text { nary, costs = f (tea- } \\
\text { perature, eallnity), } \\
\text { pdf }\end{array}$ & $\begin{array}{l}\text { Life-cycle } \\
\text { costing, } \\
\text { eacalation, } \\
\text { debt, taxes }\end{array}$ & $\begin{array}{l}\text { NPV, } \\
\text { Avalla- } \\
\text { bllity, } \\
\text { Levelized } \\
\text { busbar } \\
\text { cost, } \\
\text { Probab11- } \\
\text { ley of In- } \\
\text { vestrent }\end{array}$ & $\begin{array}{l}\text { Probabllistlc, } \\
\text { Comblation of } \\
\text { several seperate } \\
\text { models, Detalled } \\
\text { forecast1ng } \\
\text { analys18. }\end{array}$ \\
\hline $\begin{array}{l}\text { UNIV : OF } \\
\text { TEXAS }\end{array}$ & $\begin{array}{l}\text { Yea, } \\
\text { Pinite } \\
\text { aquifer }\end{array}$ & Input & $\begin{array}{l}\text { Calculateo devalop- } \\
\text { gent ecenario for a } \\
\text { given reeervolr. } \\
\text { Injectlon, ouccene } \\
\text { ratlo, odn }\end{array}$ & Coets Input & $\begin{array}{l}\text { Life-cycle } \\
\text { costing, } \\
\text { taxes, } \\
\text { escalation }\end{array}$ & NPV & \\
\hline VENVAL & $\mathbf{N} / \mathbf{A}$ & Input & $\begin{array}{l}\text { Uoer Input: conplete } \\
\text { cost achedule. }\end{array}$ & $\begin{array}{l}\text { Ueer Inputa conplete } \\
\text { coet achedule. }\end{array}$ & $\begin{array}{l}\text { Life-cycle } \\
\text { costing, } \\
\text { debt, taxes } \\
\text { much flexl- } \\
\text { bility for } \\
\text { uexdefined } \\
\text { parametera }\end{array}$ & $\begin{array}{l}\text { NPV, IRR, } \\
\text { Levelired } \\
\text { energY } \\
\text { cost, etc. }\end{array}$ & Probablliatic \\
\hline WELCST & $N / A$ & $\begin{array}{l}\text { Detalled cal- } \\
\text { culation of } \\
\text { driling and } \\
\text { completion } \\
\text { coots. Ueer } \\
\text { may vary } \\
\text { opectific } \\
\text { coats and } \\
\text { efficlencles }\end{array}$ & $\mathbf{N} / \mathbf{A}$ & $N / A$ & $\mathbf{R} / \mathrm{A}$ & $\begin{array}{l}\text { One tine } \\
\text { cost }\end{array}$ & - \\
\hline
\end{tabular}

Table 3: Summary of Key Economic Descriptors (continued) 
of Information for certain basic reservolr parameters of Known Geothermal

Resource Areas (KGRA's), such as temperature, depth, rock hardness, and brine composition.

\section{We11 costing}

Almost all of the models listed include well costs. For some studies, the cost of drilling a well must be input by the user from actual or best guess estimates. A number of the models use various simplified costing equations where, based on known data, the well cost 1 s defined in terms of depth and rock hardness. WELCST is a detailed drilling cost model which accounts for all of the major activities in the drilling process -- 1ts primary goal is to project the effect of improvements in specific technologies to the overall cost of drilling a well. HDR3 has the option of using elther a costing equation or a subprogram which outputs the cost of a well based on the results of a rigorous feastbility study. The GPPROG model uses a simpler algorithm, where costs are based on the results of a separate study. The GEOCOM model computes inftial drilling costs from a data base assembled from actual wells in six KGRA's. It also considers the lifetime operation and maintenance costs of the well. It allows the scheduling of workovers (such as stimulation, descallng, reperforating, etc.) which improve well performance. The costs and effectiveness of these procedures can be varied to simulate the impact of technological improvements on life cycle well costs.

The well-cost equations used in the various models vary greatly and can yield quite different cost estimates using the same input parameters. This has been demonstrated in a study of the various geothermal district heating cost models (Reistad, 1983). As a rule, regardless of the costing methodology employed, the user has the option of overriding those costs if actual estimates are known. 
Fleld Development and Production

This column lists the Important parameters considered by each model pertalning to the geothermal fleld. The lmportant factors as listed in Table 3 are discussed below.

(1) Modeling of the exploration phase of fleld development is of ten defined in terms of the cost and duration of this phase. Some models have the option of defining this in terms of a probability distribution function.

(2) The success rat1o accounts for the costs incurred in drilling dry wells (non-producers). This is usually expressed as a fixed percent, with a given cost per dry we11, thereby Increasing the cost per well in proportion to the success ratio.

(3) If well life is considered, costs are also included for drilling replacement wells as the need arises.

(4) Other factors, 1.e. Injection, downhole pumps, brine treatment, and operation and maintenance $(O \& M)$, are self-descriptive. Those parameters considered by the Individual models are so indicated.

\section{Energy Conversion}

The end uses considered by the varlous models are district heating and cooling, sma11 scale space heating, process heat, methane production (from geopressured resources), and electric generation (dry steam, flashed, and binary cycles). These are shown where Indicated in Table 2. Table 3 elaborates on the key factors relating to energy conversion included in each model.

A number of the models (GEOCOST, GEOCITY, etc.) use costing equations which are based on component sizes - these sizes are determined from thermodynamic relationships. A few of the models (both GEOTHM models, DHM, GEOCITY) perform some englneering design optimization. Operation and malntenance charges are usually included - some programs compute them as a function of brine salinity. In three models (BTHERM, GELCOM, and GEOTHM [LBL]), the system costs are based 
on costs of existing systems.

Most of the direct use models include the option of a clean water system with an Intermediate heat exchanger. BTHERM, DHM, GEOCITY, and GRITS calculate heat demand based on such parameters as population and climate. Other models simply define the end use in terms of a required temperature drop and total heat flow.

\section{Financial Analysis}

The models which include financlal analysis generally use one or more of the large number of methods which fall under the general classification of "engineering economics." As Indicated in Table 3, those which perform life-cycle costing use some form of discount rate to account for the time value of money. Among the other parameters incorporated into the various models are taxes (federal, state, property), Insurance, varfous debt structuring (loans, common or preferred stock, bonds), and inflation. All models which account for taxes also include tax benefits such as credits and depreciation. The models so Indicated consider price escalation - the increase in real costs of capital replacements, fuel, or other expenses. It is possible that price escalation may be included in some others, but it is not apparent in the avallable documentation.

\section{Output}

The outputs of the programs 11sted in Table 3 include:

(1) One time cost: The inftial cost of a given system, not considering Iifetime factors. This is also known as first year cost.

(2) Net Present Value (NPV): The sum of the total value of all cash flows (expenses and profits) over the life of the project, discounted to the start-up or other base-year date.

(3) Payback Perlod: For a given cash flow and set of financlal conditions, this is the amount of time required from the inftial investment for the net 
present value to reach zero (breakeven point).

(4) Internal Rate of Return (IRR): This is the overall discount rate which yields a net present value of zero over the lifetime of the project.

(5) Levelized Energy Cost: Th1s is the selling cost of energy which results In a NPV of zero over the system $11 \mathrm{fe}$, for an assumed discount rate. This is useful in comparison with alternative energy sources.

\section{Miscellaneous}

This column of Table 3 lists some unique characteristics of specific models. One of the more 1mportant of these is the use of probability distribution functions (pdf's) to define certain parameters. When this is incorporated into the model's 1nput, the output of the program will also be in the form of a pdf. This is more valuable than a single point estimate, as it provides some measure of characterizing the risk in a given project, in the form of ranges of costs, prices, or rates-of-return.

Another unique output is that of the Technecon model which predicts the likelihood of a fleld developer and/or a utility investing in a particular project given information about possible cash flows, risks involved, etc. The equations for this prediction are the results of extensive surveys of Industry and utility decision makers. This program also optimizes the selling price from developer to utilfy to maximize the likelihood of both investments. This particular analysis is very useful in forecasting future geothermal development. It is also of great interest because the financial theory behind it has been well documented (Blair et al., 1982).

Other special characteristics of the programs are detalled in the following Individual abstracts. 


\subsection{Model Descriptions}

The following subsections provide a synthesis of each of the identified economic models. Each model is described under a standard format for comparison. 


\subsubsection{BTHERM}

DEVELOPED BY: New Mexico Energy Institute

New Mexico State University

Las Cruces, NM

AUTHORS :

Roy A. Cunniff, Gary Glazner, Mark Houldsworth

DATES :

User's Manual pub1ished May 1980

PURPOSE :

The BTHERM Model provides an overview of the economic factors involved in a geothermal direct use profect, efther district heating or process heat applications.

ENERGY

EXTRACTION: The user inputs the time required for exploration and field development. The reservoir is characterized by depth and temperature. Inputs include required flow, well cost for production and injection wells, the drilling success ratio, and the well spacing. Well $11 \mathrm{fe}$ is assumed to be equal to project life. New production wells are drilled as the system expands and additional capacity is required.

\section{ENERGY}

CONVERSION: This simulation is applicable to district heating (city or subdivision), industrial process heating, small scale commercial projects, and domestic hot water. In district heating, districts (approximately 3,000 people) are quantified in terms of population density and commerclal to residential ratios. Additional development is modeled by selecting lag time for the bringing of new districts on line. The heat demand 18 determined frcm heating degree days and the design temperature. The cost equations are based on studies of Icelandic data. In the modeling of a commercial complex, the peak heat demand is the critical factor. Process heating is also characterized by the heat demand--the temperature requirements are not a factor.

All applications include the possibilities of retrofit and expansion. Operating costs are a fixed percentage of capital costs.

FINANCIAL

PARAMETERS: The program can be used to simulate either a public utility or a private developer project. Output includes total costs and a levelized cost for heat supplied. Costs for resource investigation, system design, and land leasing are included. The user inputs the percent of capital to be financed and the interest rate. State, federal, and property taxes are considered, as well as tax credits, depreciation, and depletion allowances. Conventional energy costs are subject to escalation. The discount rate used is the total interest rate specified. All default costs are in 1980 dollars. 
COMPUTER

CODE :

The program is interactive. There is also the possibility of using multi-valued parameters whereby multiple runs will be made.

AVAILABILITY: Unknown.

REFERENCES :

Cunniff, R. A.; Glazner, G.; Houldsworth, M.; Geothermal Energy For Res1dential, Commercial, Industrial Uses. A Computer Simulation Model, BTHERM. NMEI 30-5, December 1979.

Cunniff, R. A. et. al. User's Guide to BTHERM MMEI 30-22, May 1980.

Glazner, G.; "Modelling Geothermal District Heating Systems," Geothermal Resources Council, Transactions Vol. 5, October 1981, pp. 639-641.

Houldsworth, M.; "An Optimum Fuel Mix Mode1 For Geothermal District Space Heat1ng Systems,; Geothermal Resources Counc11, Transactions Vo1. 5, October 1981, pp.

See also: Reistad (1983), EER (1982)

KEY WORDS: District Heating, Process Heat, Space Heating, Field Development, Life Cycle Costs. 


\subsubsection{DHM: District Heating Model}

DEVELOPED BY: Brookhaven National Laboratory

Upton, L.I., NY 11973

AUTHORS: $\quad$ Ann Relsman, J. Karkheck

DATES: $\quad$ Published late 1980, active through 1981

PURPOSE: The program is written to provide a means of assessing the economic feasibility of geothermal district heating for any community in the United States.

ENERGY

EXTRACTION: The program accesses a data base with information of the geothermal resources of 13 western states. The 1nput to the program, either from the data base or user input, includes depth, temperature gradients, porosity, rock hardness, and chemical composition of brine. Based upon the heat requirements and local geothermal resource, the program determines the required number of wells and calculates the associated cost.

ENERGY

CONVERSION: The program considers district heating (space and domestic hot water) by geothermal fluid, with the possibility of ofl or gas for supplementary and peak heating. It optimizes, by cost, the percentages of geothermal and conventional backup capacity. In determining the district heat requirements, the program accesses a Census Data Base (1970) and a County Data Base. These supply inputs, for the chosen location, on costing factors, weather, heat requirements, area, fuel costs, and the categorization of the area to be heated (1.e., residential, commercial, etc.; there is a total of 12 categorles). Based upon flow requirements, plping costs, etc., the program optimizes the cost of the district heating system. There is also the possibility of using a retrofit system. Operating costs are included.

FINANCIAL PARAMETERS :

The program calculates the levelized cost of heat from the district heating system. The user Inputs the discount rate. Taxes and investment tax credits are included, and there is the option for time-phasing the construction and capital expenditures. Public or private ownership may be selected.

COMPUTER

CODE :

The program is in FORTRAN and is designed to be interactive. At present, there 18 no documentation avallable.

AVAILABILITY: Funding of this project was terminated before the documentation and user's manual could be developed. The code 1tself can be obtained from Brookhaven, but would require considerable assistance from the authors to operate in its present state. 
REFERENCES :

Relsman, A.; Karkheck, J.; District Heating Model, An Overview, BNL-28251, October, 1980 .

Reisman, A.; A Generic Model for District Heating and Geothermal Application, BNL-28892, November 1980 .

Reisman, A.; A Geothermal-District-Heating Assessment Model for Decision Making, BNL-30442, November 1981.

Reisman, A.; Peterson; The Economic Feasibility of Geothermal District Heating, A Case Study, BNL-30670, December 1981.

See also: Reistad (1983), EER (1982)

KEY WORDS: District Heating, Western Resources, Resource Data Base, Life-Cycle Costing. 
2.3.3 GCFM: Geothermal Loan Guaranty Cash Flow Model

DEVELOPED BY: METREK Division

The MITRE Coporation

McLean, VA

AUTHORS: $\quad$ Mark Keimig, Joseph Rosenberg, Daniel Entingh, Coleman Blake

DATES :

Published November 1980. Revisions published through February 1982

PURPOSE: The model estimates project costs and cash flows for geothermal producers and electric plants throughout the construction and operation phases. It was written for the purpose of assisting in the analysis of DOE Geothermal Loan Guaranty applications.

\section{ENERGY}

EXTRACTION :

ENERGY

CONVERSION :

FINANCIAL

PARAMETERS :
The fleld program module calculates the year by year costs associated with developing and operating the geothermal fleld. The reservoir is characterized by its depth, wellhead temperatures, pressures, and brine composition. It is modeled as an infinite system with constant parameters over the lifetime. Drilling costs are a function of depth and rock hardness or can be input by the user. There are costs for production and injection wells. A success ratio for drilling is also input. The user defines the flow rate per well, and the program calculates if downhole pumps are necessary. Well life is input to determine the schedule of replacement well drilling. Ten different fleld designs can be stored in the computer memory while running the program to perform comparisons and sensitivity analyses. Default values are included in the program, based on a detalled industry survey, to allow performance of preliminary calculations with minimal information. The costing equations are based on MITRE's GELCOM Mode1, updated to 1979.

The power plant program module can be used to study dry steam, single or dual flash, and binary systems. Costing equations are based upon the GEOCOST Model (Battelle-PNL). User controlled variables include turbine/generator efficiencies, outlet temperature, coolant temperature, pump types, etc. The model calculates brine flow requirements which are then input to the field program module. Plant life is 50 years. As with the field module, up to 10 plant types can be stored as data sets to perform sensitivity analyses. Default values used in preliminary studies can be replaced in the analysis as data becomes avallable. Life cycle costs such as operation and maintenance, capital asset replacement, and salvage value are considered.

The financial program module has as input the initial and year by year costs from the other modules and outputs a year by year cash flow and a levelized busbar cost. Inttal debt is structured to provide as much leverage as possible, loan life and a sinking fund are designated by the user. State, federal and property taxes are included, as well as tax credits, tax benefits, depreclation, deple- 
tion allowances, etc. Electriclty prices, geothermal fluid prices, and capital costs are subject to escalation and inflation. There 1s the possibility o store up to 15 financial data sets. The model can consider elther producers or utilities in a given run, but not in combination. All values are in 1979 dollars, but cost indexes exist in the equations to update the values.

COMPUTER

CODE :

AVAILABILITY: The program, Version 5.0, is avallable from the National Engineering Sof tware Center at Argonne, with Revistons through February 1982. The code is avallable for IBM 370 or $303 x$ series systems. The DOE Geothermal Loan Guaranty Program, DOE San Francisco Operations Office, has the HP-3000 version.

\section{REFERENCES :}

Kelm1g, M.A., Rosenberg, J.I.; Entingh, D.J. Geothermal Loan Guaranty Cash Flow Model - Description and User's Manual, MTR-80W160, November, 1980 .

See also: EER (1982), Ziman (1983)

KEY WORDS: Electric Power Plant, Steam Cycle, Binary Cycle, Field Development, Life-Cycle Costs. 


\subsubsection{GEEF: Geothermal Englneering and Economic Feasibility Model}

DEVELOPED BY: Englneering and Economics Research, Inc.

Falls Church, VA 22043

AUTHORS :

DATES :

Published May 1981

PURPOSE :

The program is designed to perform preitminary economic feastbility assessments of using geothermal energy in direct process heat applications, in comparison with other avallable energy sources.

ENERGY

EXTRACTION: The resource is characterlzed by the wellhead temperature, depth (production and infection wells), brine salinity, well flow rate, and rock hardness. There is a fixed cost for fleld exploration, which the user may set. Field development is performed over a perlod of 3 years, well costs are a function of depth and rock hardness. Well life $1 \mathrm{~s}$ considered in the costs of replacement wells over the system life.

\section{ENERGY}

CONVERSION :

The model is written to consider direct process heating applications with geothermal energy. The user spectfies parameters such as process temperature, allowable temperature drop, peak load, utilization factors, and length of the distribution system. There are options for single or binary systems, supplementary heat for augmentation, and two stage processes (for high and low temperatures). The program determines the required geothermal fluld, number of wells, heat exchanger sizes, and associated costs. Operation and malntenence charges are Included, as well as capital replacement costs for heat exchangers. The program has default values for costs, but it is possible for the user to override if data is known.

FINANCIAL PARAMETERS :

The program calculates year by year cash flows, net present value (given the price of energy sold), discounted payback, and levelized energy cost. The user can specify fuel and plant costs for an alternative system and comparison data will be generated. There are options for financing: debt fraction can be varied, common stock and preferred stock are considered. Federal, state, and property taxes are included along with investment tax credits, depletion allowances, depreciation, and accounting for tangible and intanglble costs. Insurance and royalty payments are also included. Year by year costs are calculated taking into consideration inflation and price escalation in the costs of capital replacements, fuel, and operation and malntenance. All default values are in 1980 dollars. 
COMPUTER

CODE :

The program is written in FORTRAN IV for an IBM 370 system. There is no internal documentation. It is not interactive.

AVAILABILITY: The computer listing is included in Reference 1. This publication Is avallable from the NTIS as order number DE83007301.

REFERENCES :

Engineer1ng and Economics Research, Inc. GEEF: A Geothermal Engineering and Economic Feasibility Model, Description and User's Manual. DOE/ID/12174-T1, September 1982.

KEY WORDS: Process Heat, Fleld Development, Life-Cycle Costing. 


\subsubsection{GELCOM: Geothermal Levelized Busbar Cost Model}

DEVELOPED BY: METREK DIVIsion, MITRE Corporation

McLean, VA

AUTHORS: $\quad$ J.N. Gupta; J.G. Le1gh

DATES: $\quad$ Published January 1978

PURPOSE: The model can be used to project the costs of electriclty generated from a liquid-dominated geothermal resource for elther the fleld operator or the electric utility.

ENERGY

EXTRACTION: The model consilers liquid domlnated systems at temperatures greater than $150^{\circ} \mathrm{C}$. The reservolr 18 considered to be infinite in that it will not decline in productivity or limit production. It is characterized by temperature, depth, rock hardness, and brine salinity; a data file 18 included for 26 KGRA's containing this information. Well costs are determined as a function of depth and rock hardness. Costs for production wells, injection wells, and brine treatment are calculated but scheduling can be input by the user if known. Well life 18 input to determine costs and scheduling of replacement wells.

ENERGY

CONVERSION: The program considers the costs of constructing and operating electric power plants. All plants are assumed to be 50MWe, the user selects the number of plants and when they will come on line. Both flashed steam and binary power cycles are considered. The program contains 12 generic plant designs for temperature, salinity, and conversion cycle and plant costs are calculated by interpolating between these known designs. Operation and maintenance is a fixed percentage of capital cost. The user inputs plant life.

FINANCIAL PARAMETERS :

The program calculates the levelized busbar cost of produced electricity. For iffe-cycle costs, inflation and price escalation are included. The debt fraction is input with the associated Interest rates and the discount rate. Taxes, tax credits, depreciation, royalty payments and insurance are included. Costs are calculated in 1977 dollars.

COMPUTER

CODE

The program 18 written in FORTRAN IV on an IBM 370 system. It is designed to be interactive from a remote terminal. Sensitivity analysis will be performed as required on critical parameters such as temperature, capacity factor, drilling costs, tax credits, etc. 
AVAILABILITY: The computer code, with data flles, is included in Reference 1. REFERENCES :

Gupta, J.N.; J.G.; GELCOM: A Geothermal Leve 1zed Busbar Cost Mode1, M78-17, January, 1978 .

See also: EER (1982)

KEY WORDS: Electric Power Plants, Steam Cycle, Binary Cycle, Fleld Development, Resource Data Base, Life-Cycle Costing. 
DEVELOPED BY: Battelle, Paclfic Northwest Laboratory

Richland, WA 99352

AUTHORS: Harlan Huber, Clarence Bloomster, LInda Fassbender

DATES: Original version published October, 1978. Updated version, September 1982 .

PURPOSE: $\quad$ GEOCITY is a large-scale simulation model which combines both engineering and econorics to systematically calculate the cost of geothermal district heating systems for space heating and cooling.

ENERGY

EXTRACTION: The exploration, development, and operation of the geothermal fleld are simulated in the reservoir model. Costs for fleld exploration are determined in a seven step process, each step of which is characterized by input costs, time, and success ratios. Alternatively, the user can input these costs directly. The reservoir itself is modeled as a constant (over time), Infinite system. In the development stage, the user can specify the well design, whereby costs are calculated from default values (function of depth, diameter, bottom-hole-temperature, percent of well cased, rock hardness) or the costs per well can be input directly. The ratio of producers to dry wells is considered. Based upon wellhead characteristics (temperature pressure, flow rate, geothermal $f(u i d)$ and fluid requirements, the transmission system is sized and priced. Downhole pumps are used if needed. All calculated costs can be overridden with input data. Costs for injection wells are included. Costs for interim capital replacements and operation and maintenance are a function of captal costs and fluid chemistry. Well life is input directly. Fluid characteristlcs are determined from ASME Steam Tables, Incorporated into the computer code.

\section{ENERGY}

CONVERSION: The GEOCITY Computer Program considers domestic hot water heating, space heating, and space cooling*. The demand is calculated based upon climate (degree days, design temperatures), population, and area. A city $1 \mathrm{~s}$ divided into districts, each of which is characterized as one of six standards types (high density, single family; high-rise apartments; etc.) with an assoclated demand profile. Other types may be spectfled by the user. The program designs the distribution system and calculates fluid requirements to meet the needs. It also determines pipe sizes and materials, insulation, and physical layout. Pipe sizes and insulation are optimized on a minimum cost basis, with regard to heat 10 ses. Optionally, a binary system with heat exchanger may be chosen, or the capability of wellhead fluid mixing*. Operation and

* Asterisk indicates options which are only available in 1982 version. 
maintenance, electrical pumping, and supplemental heating costs are included. The distribution model is derived in part from SOLTES, a solar energy district heating design code written at Sandia National Laboratories.

FINANCIAL

PARAMETERS :

For both the producer and distributor, the model calculates the levelized cost of energy. The reservoir model cost output is input to the distribution economics mode1. There are options for debt or equity financing, and the discount rate is calculated from the corresponding interest rates. State, federal and property taxes are included as well as tax credits and depreciation. Tangible and Intangible costs are differentlated for tax purposes. Insurance and royalty payments are included. E1ther a private enterprise or a public ut1lity 1 s selected by the user for consideration. Escalation* of capital replacement and fuel costs is avallable. Maximum project life 1850 years. Costs are In 1980 dollars.* Indexes are avallable to escalate base-year costs to the desired year.

COMPUTER

CODE :

The program is written in Fortran IV and is not interactive. Code for the ASME steam Tables is included for thermodynamic calculations.

AVAILABILITY: The 1978 version (described here) is avallable from the National Energy Software Center, Argonne, IL, in source deck or magnetic tape for CDC6600 and CYBER74 computers. The user's manual is avallable either through NESC or NTIS. An updated version of the code (circa approximately 1982) has been completed at PNL but not released. The updated user's manual is avallable from NTIS.

\section{REFERENCES :}

McDonald, C.L.; Bloomster, C.H.; Schulte, S.C. GEOCITY: A Computer Code for Calculating Costs of District Heating Using Geotherma1 Resources. BNWL-2208, February, 1977.

McDonald, C.L.; Bloomster, C.H. The GEOCITY Model: Description and Application. BNWL-SA-6343, June, 1977.

Huber, H.D.; McDonald, C.L.; Bloomster, Schulte, S.C. User Manual for GEOCITY: A Computer Model For District Heating Cost Analysis. PNL-2742, October 1978.

Huber, H.D., Fassbender, L.L.; Bloomster, C.H. User Manual For GEOCITY: A Computer Model For Geothermal District Heating Cost Analysis. PNL-4422, September 1982 .

\footnotetext{
*Asterisk indicates optlons avallable in 1982 version only.
} 
Fassbender, L.L.; Bloomster, C.H.; The Economics of Power Plant Dlstrict and Process Heating in Richland, Washington. PNL-3719, April 1981.

See also: EER (1982), Relstad (1983), Ziman (1983).

KEY WORDS: District Heating, District Cooling, Englneering Design, Field Development, L1te-Cycle Costs. 


\subsubsection{GEOCOM}

DEVELOPED BY: The BDM Corporation

Albuquerque, NM 87106

AUTHORS: $\quad$ E. R. Anderson; W. C. Hoessel, A. J. Mansure,

DATES: $\quad$ Published July 1982

PURPOSE: The GEOCOM model is designed to evaluate the cost effectiveness of various technologies in well completion, production, and maintenance. Emphasis is placed upon the lifetime cost and performance of a geothermal well.

\section{ENERGY}

EXTRACTION: The characteristics of six KGRA's are included in the program's data base (Brawley, Heber, Geysers, Baca, Roosevelt Hot Springs, and East Mesa). These parameters are depth, completion interval, well head temperature, average well $11 \mathrm{fe}$, Inttial well flow, dissolved solids, steam fraction, and exponential reservolr decline rate. For each KGRA, the well design and initial cost is based upon the data base assembled in Reference 3.

The emphasis of the simulation 18 on the operations phase of the we11 iffe. Operation and maintenance costs are a percentage of capital costs. Pumping and chemlcal treatment costs are calculated from the amount of fluld produced. There are 12 workover types included in the program; the user selects up to 3 and sets the frequency at which they will be performed. The resulting 1mprovement of well flow as a result of the given workover 18 also included. All calculations in the program are for a single well.

ENERGY

CONVERSION :

Costs for conversion or distribution are not considered. The user specifies what the end use is to be (electric, direct heat, total energy, injection well) and the program, based on simple equations and ideal efficlencies, calculates the value of the fluid extracted. In the case of infection wells, the output is the cost in s/gallon injected.

FINANCIAL PARAMETERS :

The output of the program is 11 fe-cycle cost/11fe-cycle benefit. The Inflation and discount rates are input to determine net present value of all costs.

COMPUTER

CODE :

The computer program is written in FORTRAN (1966 version).

AVAILABILITY: A list of the computer code is included in Reference 1. The program is presently installed on the Sandia National Laboratories' NOS computer. 
REFERENCES :

Anderson, E. R., et. al. Geothermal Completion Technology Life-Cycle Cost Mode1 (GEOCOM), SAND 82-7006, July 1982.

Brown, G. L. Geothermal Wells - The Cost Benef 1t of Fracture Stimulation Estimated by the GEOCOM Code, SAND 83-7440, September 1983.

Carson, C. C.; Lin, Y. T.; Livesay, B. J. Representative Well Models for Eight Geothermal Resource Areas, SAND 81-2202, February 1983.

KEY WORDS: Field Development, Drilling Costs, Life-Cycle Costs. 


\subsubsection{GEOCOST: Geothermal Cost Analysis, Steam Cycle Version}

DEVELOPED BY: Battelle, Pacific Northwest Laboratories

Richland, Washingt on 99352

AUTHORS: Harlan Huber, Clarence Bloomster, Linda Fassbender.

DATES :

User's manual published March, 1976. Code updated through approximately 1984 but not published.

PURPOSE :

The GEOCOST program simulates the over-all design, including major components, of a geothermal steam electric power plant. Components are sized based upon themodynamic relationships and costs are calculated as a function of size.

ENERGY

EXTRACTION: The exploration, development, and operation of the geothermal field are simulated in the reservolr model. Costs for fleld exploration are determined in a seven step process, each step of which is characterized by input costs, time, and success ratios. Alternatively, the user can input these costs directly. In the development stage, the user can specify the well design, whereby costs are calculated from default values (function of depth, diameter, bottom-hole-temperature, percent of well cased, rock hardness) or the total cost per well can be input directly. The ratio of producers to dry wells is considered. Based upon wellhead characteristics (temperature, pressure, flow rate, geothermal fluid) and fluid requirements, the transmission system is sized and priced. These can be overridden with input data. Costs for injection wells are included. Costs for interim capital replacements and operation and maintenance are a function of capital costs and fluid chemistry. Well life is input directly by the user. Fluid characteristics are determined from ASME Steam Tables, incorporated into the computer code.

ENERGY

CONVERSION: This version of GEOCOST considers steam powered electric generation. Based upon the specifled power plant design, capacity, and geothermal fluid characteristics, the program calculates plant size, cost, and fluid requirements. There are options for particulate removal and multi-stage flashing. Operation and mafntenance costs as well as those for replacement of components are based on inftial capital cost and flutd chemistry. Construction time for the geothermal power plant is considered.

FINANCIAL PARAMETERS :

For both the geothermal fleld and the power plant, the program calculates the levelized cost of energy. The reservoir model cost outputs are input to the power plant model. There are options for debt or equity fininc:ng and the discount rate is calculated from these interest rates. State, federal, and property taxes are included as well as tax credits and depreciation. Tangible and intangible costs are differentiated. Insurance and 
royalty payments are also included. Maximum total project life is 50 years. Costs are in 1974 dollars. Indexes are avallable to escalate base-year costs to the desired year.

COMPUTER

CODE :

The program is written in Fortran IV and 18 not interactive. Code for the ASME Steam Tables is included for thermodynamic calculations.

AVAILABILITY: The 1975 version (described here) is avallable from the National Energy Sof tware Center, Argonne, IL, in source déck or on magnetic tape for CDC 6600 and CYBER74 computers. The user's manual 18 avallable elther through NESC or NTIS. An updated version (circa approximately 1984) of the code has been worked on at PNL but has not been released.

\section{REFERENCES :}

Bloomster, C.H., et al; GEOCOST: A Computer Program for Geothermal Cost Analys 1s, BNWL-1888, February, 1975.

Bloomster, C.H.; "An Economic Model for Geothermal Cost Analysis," Proceedings, 2nd United Nations Symposium on the Development and Use of Geothermal Resources, May 1975, pp. 2273-2282.

Huber, H.D.; Bloomster, C.H.; Walter, R.A.; User's Manual for GEOCOST: A Computer Model for Geothermal Cost Analys1s, Volume 1, Steam Cycle Version, BNWL - 1942-V1. November 1975.

Cohn, P.; Bloomster, C.H.; Capital Cost Models for Geothermal Power Plants, BNWL-1990. July, 1976.

Schulte, S.C.; Capital Cost Models for Geothermal Power Plants and Fluid Transmission Systems, PNL-2307. September 1977.

See also: EER (1982), Ziman (1983)

KEY WORDS: Electric Power Plants, Steam Cycle, Engineering Design, Field Development, Life-Cycle Costing. 


\subsubsection{GEOCOST-BC: Geothermal Cost Analysis, Binary Cycle Version}

DEVELOPED BY: Battelle, Pacific Northwest Laboratories

Richland, WA 99352

AUTHORS :

Harlan Huber, Clarence Bloomster, Linda Fassbender.

DATES :

User's manual published March, 1976. Program updated through approximately 1984 but not released. Updated user's manual has not been written.

PURPOSE :

The program simulates the over-all design, including all major components, of a geothermal binary electric power plant.

Components are sized based upon thermodynamic relationships and costs are calculated as a function of size.

\section{ENERGY}

EXTRACTION: The exploration, development, and operation of the geothermal field are simulated in the reservoir model. Costs for fleld exploration are determined in a seven step process, each step of which is characterized by input costs, time, and success ratios. Alternatively, the user can input these costs directly. In the development stage, the user can specify the well design, whereby costs are calculated from default values (function of depth, diameter, bottom-hole temperature, percent of well cased, rock hardness) or the costs per well can be input directly. The ratio of producers to dry wells is considered. Based upon wellhead characterization (temperature, pressure, flow rate, geothermal fluid) and fluid requirements, the transmission system is sized and priced. These inputs can be overridden with user-defined data. Costs for injection wells are included. Costs for interim capital replacements and operation and malntenance are a function of capital costs and fluid chemistry. Well life is input directly. Fluid characteristics are determined from ASME Steam Tables, Incorporated into the computer code.

\section{ENERGY}

CONVERSION :

This version of GEOCOST considers geothermal electric power generation using the binary cycle. One of 10 avallable working fluids is selected, and dependent upon the characteristics, either subcritical or supercritical Rankine Cycles are selected by the program (although the user may override). Power plant life, load factor, capacity, and design are input. The program calculates component sizes (and costs), fluld requirements, and parasitic power loads. Operation and maintenance costs, as well as those for replacement of components, are based upon plant size, capital costs, and fluid chemistry.

PINANCIAL PARAMETERS :

For both the geothermal field and the power plant, the program calculates the levelized cost of energy. The reservolr model cost output is input to the power plant model. There are options for debt or equity financing and the discount rate is calculated from these interest rates. State, federal, and property taxes 
are included as well as tax credits and depreciation. Tangible and intangible costs are differentiated. Insurance and royalty payments are also included. Maximum total project $11 \mathrm{fe}$ is 50 years. Costs are in 1974 dollars. Indexes are avaflable to escalate base-year costs to the desired year.

COMPUTER

CODE :

AVAILABILITY :

REFERENCES :

Bloomster, C.H., et al; GEOCOST: A Computer Program for Geothermal Cost Analysis, BNWL-1888, February, 1975 .

Bloomster, C.H.; "An Economic Model for Geotherma1 Cost Analysis," Proceedings, 2nd United Nations Symposium on the Development and Use of Geothermal Resources, San Francisco, CA, May 1975, pp. 2273-2282.

Huber, H.D.; Walter, R.A.; Bloomster, C.H.; Users Manual for GEOCOST: A Computer Model for Geothermal Cost Analysis, Volume 2, Binary Cycle Version, BNWL - 1942-V2. March 1976.

Cohn, P.; Bloomster, C.H.; Capital Cost Models for Geothermal Power Plants, BNWL-1990. July, 1976.

Walter, R.A.; Modeling and Optimization of Geothermal Power Plants Using the Blnary Fluid Cycle, BNWL-2112. September 1976.

Schulte, S.C.; Capital Cost Models for Geothermal Power Plants and Fluid Transmission Systems, PNL-2307. September 1977.

See also: EER (1982), Ziman (1983)

KEY WORDS: Electric Power Plants, Binary Cycle, Engineering Design, Field Development, Life-Cycle Costing. 
DEVELOPED BY: Lawrence Berkeley Laboratory

Berkeley, CA 94720

AUTHORS: M. A. Green; H. S. PInes; W. L. Pope; J. D. Williams; R. N. Healey;

L. F. Silvester

DATES: $\quad$ User's manual publlshed July 1977

PURPOSE: The program allows the optimlzation of the design of a geothermal electric power plant to minimize a user selected objectlve function (such as busbar cost, capital cost, losses, etc.).

ENERGY

EXTRACTION: The reservolr is modeled as a unfform, semi-infinite system with no decline as a function of time. The user spectfies reservolr temperature, depth, and drawdown. Well costs are input directly, production, injection, and spare wells are 1ncluded. The fleld may be free flowing or utflize downhole pumps.

ENERGY

CONVERSION: The model is able to consider single or dual stage flash, binary, or flash/binary hybrid systems. The program performs thermodynamic modeling using the equations of state and the energy equation. S1x parameters are considered (turbine inlet temperature and pressure, condensing pressure, pinch polnt temperatures for primary heat exchanger and condenser, and cooling tower temperature). Efficlencies of generators, motors, and pumps are input. The user selects permissable ranges for the variable parameters as well as which of them may be altered in the optimization routines. Costs of the system are based upon the sizes of components (spectfled by the thermodynamics) and are calculated by normalizing the EPRI cost estimates of the Heber Power Plant.

The main feature of the program is the optimization capability, whereby user selected parameters are varied to optimize the user defined objective function.

FINANCIAL

PARAMETERS: There are no formal costing routines or financial calculations performed.

COMPUTER

CODE :

The program is written in FORTRAN, and installed on a CDC 7600 computer.

AVAILABILITY: Unknown .

REPERENCES :

Green, M. A., et. al. GEOTHM - Part 1, A User's Manual for GEOTHM (Computer Design and Simulation of Geothermal Energy Cycles) LBL publication-202, July 1977. 


\section{REFERENCES :}

Green, M. A.; Plnes, H. S.; Pope, W. L.; Williams, J. D. Thermodynamic and and Cost Optimization Using Program GEOTHM, LBL-6303, Apri1 1977.

Pines, H. S.; Green, M. A. Use of GEOTHM to Design and Optimize Geothermal Power Cycles, LBL-4454, June 1976.

Pope, W. L. et. al. "Conceptual Design Cptimization," Sourcebook on the Production of Electrictiy frow Geothermal Energy, DOE/RA/4051-1, March 1980, pp. 729-772.

KEY WORDS: Electric Power Production, Steam Cycle, Binary Cycle, Engineering Design, Optimization. 


\subsubsection{GEOTHM}

DEVELOPED BY: Massachusetts Institute of Technology

Department of Mechanical Englneering

Cambridge, MA 02139

AUTHOR: $\quad$ Michael B. Packer

DATES: $\quad$ Published May, 1980

PURPOSE: The goal of this model is to serve as an ald in the evaluation of the technical and economtc feastbility of process heat app11cations using geothermal energy.

ENERGY

EXTRACTION: The program uses a simplified method to calculate the cost of developing a geothermal field. Costs for exploration and resource assessment are not considered. Inputs to the program include well head temperatures, pressures, flow rates, the number of wells to be drilled, and the percentage of dry wells. The costs for fleld development are based on the number of wells drilled, times a cost per well (user-input). Other costs considered are that for the fluid transmission system, the acquisition of land, and general miscellaneous. To account for the degradation of the geothermal wells over time the user inputs the number of new wells to be drilled each year.

\section{ENERGY}

CONVERSION

The program is designed for process heat applications only. It can consider a user defined set of processes, each having a given temperature input and output and total heat requirement. The program will optimize the arrangement of the fluld distribution system (based on cost) to serve all required end uses. Costs for the various components (plping, heat exchangers, etc.) have default values in the program. The user has the option of not using the program's optimlzation routines and directly inputting the end uses and costs. The program can handle liquid, steam, or biphase flow as well as using a binary system if selected by the user. There is also the option of supplementary heating of the fluid if the temperatures are inadequate. For the system operation, the electric requirements of pumps, etc. are calculated. Maintenance costs are determined as a constant percentage of initial investment.

FINANCIAL PARAMETERS :

The program calculates inftial investment and annual costs and determines 1 ) the net present value of the system; 2) the discounted payback perlod; and 3 ) the internal rate-of-return. Costs are divided into tanglble and intanglble costs for tax and depreclation purposes. Financing can be done with various debt/equity rat $10 s$ and through loans, bonds, or other. Investment and energy tax credits are considered. Costs for supplementary fuels and the value of energy sold are glven by the user. Continuous costs include insurance, property tax, and royalty payments. All calcula- 
tions include inflation and price escalation (1nput by user). The program uses 1978 dollars.

COMPUTER

CODE :

The program is written in FORTRAN, is internally documented, and is not interactive. There 18 the option to perform multiple runs with different data to do sensitivity analyses.

AVAILABILITY: The computer code is included in Reference 1. Th1s publication is avallable in microflche form or photocopled from NTIS or the MIT 11brary.

REFERENCES :

Packer, Michael B. A Method for Evaluating the Potential of Geothermal Energy in Industr1al Process Applications, DOE/ET/28508-04. May 1980.

KEY WORDS: Process Heating, Optimization, Engineering Design, Life-Cycle Costs, Field Development 
DEVELOPED BY: Jet Propulsion Laboratory

California Institute of Technology

Pasadena, CA

AUTHORS :

DATES :

PURPOSE :

ENERGY

EXTRACTION:

Tom K. Lee, Lowe11 Orren, G. Michael Ziman, Sue Campbell Jones

Published August 1981

The GPCM model determlies the probablity distribution function of the cost of developing a geothermal fleld, in terms of the distribution function of the input variables. It does not model end use systems.

The user divides the project iffe into various stages (for example: resource definftion, permiting, reservolr development, and operation). The length and costs associated with each stage are input as constants or as pdf's. The user must construct a base case scenario including the number of production and Injection wells, flow rate, well $11 \mathrm{fe}$, depth, temperature, and associated costs. The program has the capability to include any additional physical relationships which the user would input. These could include reservolr modeling, flow modeling, etc. If reservolr or well productivity decline is included, a redrilling program is automatically designed to maintain the required heat flow from the wells.

Any physical, economic, or time parameters may be assigned a discrete probability distribution function. Bivariate distributions are also possible. Using a decision tree approach, the model calculates the probability and cost of all possible outcomes.

ENERGY

CONVERSION: In the model itself, the values of total fluid production and plant energy requirements are input to size the production field. The user has the option of modeling the end use system by entering the necessary physical and costing equation subroutines into the program.

FINANCIAL

PARAMETERS: The GPCM calculates 11 fe-cycle cost for a profect as well as levelized cost of production. The output is a probability distribution for profit, cost, and required capital expenses. Expenditures may be financed at selected debt/equity ratios elther with common stock, preferred stock, or loans. Taxes, credits, deprectation, depletion allowances, and royalty payments are Included. Other inputs are the price and value of energy, escalation, inflation, and the discount rate to be used. All calculations are based on 1980 dollars. 
COMPUTER

CODE :

The computer program 18 written in PORTRAN. The program itself could be applied to any situation as long as the user provided the necessary engineering and economic relationships.

AVAILABILITY: Unknown.

REFERENCES :

Orren, L. H., et. a1. Geothermal Probabalist1c Cost Study, NASA-CR-168757 August 1981 .

See also: EER (1982), Ziman (1983)

KEY WORDS: Field Development, Life-Cycle Cost, Stochastic Analysis. 
2.3.13 GPPROG

DEVELOPED BY: Louisiana State University

Baton Rouge, LA 70804

AUTHORS: $\quad$ Fred Wrighton, Adrain Johnson, Jr.

DATES : $\quad 1979$

PURPOSE: This program was written to provide a comprehensive set of economic data to allow analysis of the commerclal potential of geopressured-geothermal prospects in Loulslana.

ENERGY

EXTRACTION: The geopressured reservolr is modeled as a bounded, c1rcular aquifer. The user inputs area, thickness, depth, porosity, permeability, and compressibility. It is assumed to be saturated with methane at the given thermodynamic state.

Costs are considered for a single production we 11 and two infection wells. Drilling costs are based on estimates prepared by Dow Chemical (Reference 1). Operation and maintenance charges for the well and electriclty for relnjection pumps are included.

ENERGY

CONVERSION: The plant described in this simulation is a water-methane separator which will then deliver the methane to a gas company... Plant costs are determined from Reference 1. Operation and malntenance costs are Included.

FINANCIAL PARAMETERS :

The program calculates net present value and internal rate of return over the $11 \mathrm{fe}$ of the project. The study period 18 assumed to be 1985 to 2004. Federal and state taxes are Included, as well as tax credits, depreciation, and depletion allowances. The user inputs the discount rate to be used.

Alternatively, the model contains optimization routines which solve for the minimum value of an economic or physical parameter which will result in an NPV of zero. These parameter options are methane price, tax rate, solubility, and reservolr area. This optimization can be elther deterministic or based upon a Monte Carlo simulation.

Al1 cost data are based upon pre-1979 estimates, and inflated to 1985 projected dollars.

COMPUTER

CODE :

The program is written in FORTRAN and consists of a maln program and 28 subroutines and functions.

AVAILABILITY: Unknown • 
REFERENCES :

Dow Chemical Company, "A Study of a Phase ' $O$ ' Plan for the Production of Electrical Power from U.S. Gulf Coast Geopressured Geothermal Waters," Proceedings: Second Geopressured Geothermal Energy Conference Volume IV, February 1976, Append1x B.

Johnson, A. E.; et. al. Operat ons Research and Systems Analysis of Geopressured-Geotherma1 Energy In Louls1ana, DOE/ET/27085-1, Final Report June 1, 1978 - August 31, 1979.

Wrighton, F.M.; Johnson, A.E., "A Description of the Technoeconomical Model Used to Analyze the Development Potential of Loulslana Geopressured Energy Prospects," Proceedings of the Pourth U.S. Gulf Coast Geopressured Geothermil Eaergy Conference, Volume 3, 1979, Pp. 1484-1498.

Ray, T.G.; Johnson, A.E. "Sensttivity of the Economfcs of a Geopressured Energy Prospect to Variation In Geologic Parameters", Proceedings of the Fourth U.S. Gulf Coast Geopressured Geothermal Energy Conference, Volume 3, 1979, Pp. 1499-1509.

KEY WORDS: Geopressured Resources, Life-cycle Costs, Field Development Loulsiana. 


\title{
2.3.14 GRITS: Geothermal Resource Interact1ve Temporal S1mulation
}

\author{
DEVELOPED BY: Johns Hopk1ns Un1vers1ty \\ Center for Metropolitan Planning and Research \\ Baltimore, MD $2 \ddot{2} 218$
}

Johns Hopk1ns UnIversity/Applied Physics Laboratory

Laure1, MD 20707

AUTHORS: $\quad$ Richard Welssbrod, William Barron, Kwang Yu, Peter Kroll, Fletcher Paddison, William J. Toth

DATES :

Version 9 user manual published April, 1982.

PURPOSE :

The program is designed to allow the performance of preliminary economic evaluations of direct use geothermal energy applications. This enables the user to compare varlous designs and tradeoffs in performing various feasibility analyses.'

ENERGY

EXTRACTION: The model was designed as part of a study of geothermal energy development in the Eastern United States and hence considers primarily low and moderate temperature resources. The user inputs the resource characteristics - resource temperature, flow rate, drawdown (these can be input as functions of time). The reservolr 1tself can be optionally modeled in terms of the pumping cycle, heat storage, transmissivity, and well radius to determine pumping energy and drawdown. The fleld can be destgned for a single or multiple well system, with or without reinjection. Well costs are a function of depth. Downhole pumps are sized and costed, in terms of required flow rate and drawdown. Included Is a resource assessment phase for which the user selects the cost and duration. During the ut1lization phase, the wells are considered to be drilled durfing the first year. The option exists of modeling in elther a resource limited or demand limited mode.

\section{ENERGY}

CONVERSION: The model is capable of analyzing both district heat and process applications, in either a single system or binary mode. There are options for a fossil fuel boller as a topping system and a storage tank for load leveling. The user inputs the transmission system and cost, the number of houses, bulldings, or required process loads. For heating applications, the demand is determined by hourly temperature data (avallable for 134 clties, or input by user). The capital costs are calculated based on sizes and designs of the ttems. Lifetimes of capital components are input. In the case of district heating, the rate of system construction can be varied. Operation and maintenance costs are a percentage of capital costs. Maximum project life is 30 years. 
FINANCIAL

PARAMETERS: The program elther calculates levelized cost of Btu's, or the net present value of the system and discounted payback period, if the selling price of geothermal energy is known. The debt structure and interest rates are inputs, as is the discount rate. For comparison purposes as well as in determining yearly expenses, the user defines price trends for the costs of fuel and electricity. Taxes are not considered. Constant or current dollars may be used.

COMPUTER

CODE :

The program is interactive and allows the creation of a base case from which parameters may be varled for sensitivity studies. GRITS, Version 9 incorporates a number of earlier models developed in connection with the same study, Including DSM, GREES, and BIGMAC. The program is written in FORTRAN.

AVAILABILITY: The program is avallable as a listing or on tape from JHU-APL. Versions of the code have been written for IBM, DEC, and VAX systems. The latest edition of the user's guide is avallable through NTIS (orjer number PV 82246026).

\section{REFERENCES :}

Weissbrod, R.; Barron, W.; Kroll, P.; Toth, W.; Economlc Evaluation Mode1 for Direct Use of Moderate Temperature (up to $250^{\circ} \mathrm{F}$ ) Geothermal Resources in the Nothern Atlant1c Coastal Pla1n, JHU/APL, QM-79-124, June 1979.

Krol1, P; Barron, W.; Toth, W. The Demand Specified Model for Direct Applications of Geothermal Energy; A User's Guide, JHU/APL, QM-80-131, December, 1980 .

Krol1, P; Barron, W.; Yu, K.; Toth, W. BIGMAC: Basic Interactive Geothermal Model with Aquifier Characterization, a User's Guide, JHU/APL, QM-81-089, October, 1981 .

Kro11, P.; Kane, S.M. GRITS (Version 9): Model Description and User's Gu1de, JHU/APL, QM-8I-112, October, 1981.

Kane, S. M.; Kro11, P.; N110, B. Sensitivity Analysis - Cost of Geothermal Energy, JHU/APL, QM-82-004, December 1982 .

Kane, S. M.; Barron,W.F.; Padd1son, F.C.; Kro11, P.; GRITS - A Computer Program For Economic Evaluation of Geothermal Energy," ASHRAE Transactions, Volume 88, Part 1, 1982. pp. 1323-1336.

See also: EER (1982), Relstad (1983).

KEY WORDS: District Heating, Process Heat; Field Development, Life-Cycle Cost8, Eastern U.S., Moderate Temperature Resources. 
2.3 .15 HDR3

DEVELOPED BY: Los Alamos National Laboratory

Los Alamos, NM 87545

AUTHOR: $\quad$ Connle J. Arundale

DATES: $\quad$ Published October 1982

PURPOSE: Th1s program is used to estimate the total reservolr costs of a geothermal space heating system us!ng hot dry rock geothermal resources.

ENERGY

EXTRACTION: This program considers the costs associated with developing and malntaining a hot dry rock geothermal reservolr. Inputs include the geothermal gradient and the number of fractures. Dependent upon heat requirements, the model determines the most economic depth to be drilled. Temperature decline of the reservoir is calculated and the program has the option of amellorating it by efther (1) redrilling a new well to the same depth; (2) redrilling to deeper depths; or (3) using conventional energy for supplementary heating. of these three, the one with the lowest net present value is chosen by the program.

There are two options for calculating drilling costs. The program Incorporates a function, based on the GEOCOST equations, whereby well cost is a function of depth and rock hardness. The second alternative uses a subprogram, (RGICOST), where costs are based on a study by Republic Geothermal and calculated as a function of depth and other technical and geographical factors.

ENERGY

CONVERSION: The HDR3 program considers space heating applications. The user inputs the temperature drop through the system, the required heat flow, and the design temperature. These are used to calculate requirements from the reservoir. There are no calculations for designing or costing the distribution system.

FINANCIAL

PARAMETERS: The program loops on discount rate, fuel price escalation, and drilling cost escalation and determines the present value of the system and a cost-benefit ratio comparing it to the avoided cost of using conventional fuels. The output is given for each set of varled parameters.

COMPUTER

CODE :

The program is written in FOR $\mathrm{RAN}$. It is not interactive.

AVAILABILITY: The computer code for HDR3, as well as that for the auxillary program RGICOST are included in the user's manual. This publication is avallable through NTIS. 
REFERENCES :

Arundale, C. J.; User's Manual for HDR3 Computer Code, LA-9560-M, October 1982 .

Republic Geothermal, Inc. Industrial Assessment of Drilling, Completion, and Workover Costs of the Well and Fracture Subsystems of Hot Dry Rock Geothermal Systems, prepared for Los Alamos Nat1onal Laboratory, 17 March 1979.

KEY WORDS: District Heating, Hot Dry Rock Resource, Drilling Costs, Life-Cycle Costs. 


\subsubsection{TCN}

DEVELOPED BY: Technecon Analyt1c Research, Inc.

Philadelphia, PA

AUTHORS :

Thomas Cassel, Chrls Amundsen, Robert Edelsteln

DATES :

Reservolr Development program published October 1979. Ut1lity Investment module added May 1981. Hydrothermal Exploration and Discovery Model published 1982. Models updated during 1983.

PURPOSE :

The Technecon simulation provides a means for making probabilistic estimates of the commercial potential of the development of geothermal power in the United States.

ENERGY

EXTRACTION :

For predicting geothermal energy potentlal, a hydrothermal exploration, discovery, and resource quality model has been developed to project the number of future resource discoverles. The model is capable of forecasting the yearly rate of exploration activity, the number of discovelies which can be anticipated, and the 11kely quality of these resources. Incorporated in the analysis are such factors as resource depletion, economic and investment climate, and historical trends in discovered resource quality. The modeling techniques are for the first time applied to the geothermal industry, although they have been extensively used in recent ofl and gas industry evaluations. The model components are estimated from historic data, and accurately replicate past hydrothermal exploration, discovery, and resource quality trends. For a specific development, the geothermal resource is characterized in terms of temperature, depth, geology (sedimentary or 1gneous), reservoir size, and well life. Costs for early exploration, land acquisition, and preliminary studies are included as sunk costs. Well cost is a function of geology and depth. Redrilling of wells is included in the life of the project. Certain parameters may be described stochastically, specifically: resource temperature, well flow rate, well cost, and the frequency of dry wells.

ENERGY

CONVERSION :

The model considers electric power plants using either the flashed steam or blnary cycles. Plant costs are based on relatively simple algorithms as a function of temperature and salinity. Other factors included are operation and maintenance, fuel costs, plping systems, and plant efficlency. A probability distribution function may be input to describe plping costs, plant cost, and plant avallablitty.

FINANCIAL PARAMETERS :

The financial analysis calculates probabilistic descriptions of levelized busbar cost, plant ava1lability, net output, rate-of-return, net present value, and investment at risk. Factors considered include debt structure (loans, common 
stock, preferred stock), taxes, tax credits, royalties, and insurance. With the resultant probability distribution functlons, the model outputs the likelihood of both developer and utility investment in the project. This determination is based on extensive surveying of industry personnel and characterization of their attitudes. The methodology analytically compares time-wise geothermal investment opportunities to other investment opportunities avallable to resource developers and electric utilities. The program optimizes the selling cost of geothermal fluld to maximize the probabllicy of both producer and utility Investment.

COMPUTER

CODE :

AVAILABILITY:

REFERENCES :

KEY WORDS :
The TCN simulation is actualiy a series of separate but interrelated models. It is written in APL and can be run on virtually any computer with an APL compller.

The computer code is avallable from Technecon. No user manuals or formal documentation have been puslished.

Casse1, T. A. V.; Edelstein, R. H.; Blair, P. D.; Amundsen, C. B. Geothermal Investment and Pollcy Analysis with Evaluation of Callfornia and Utah Resource Areas, DOE/RA/4713-1, October 1979.

Cassel, T. A. V.; Amundsen, C. B.; Edelstela, R. H.; Blair, P. D. Geothermal Well Field and Power Plant Investment Decision Analysis, DOE/ET/27242-T1, May 1981.

Casse1, T.A.V. et al; National Forecast For Geothermal Resource Exploration and Development, DOE/ET/27242-T2, March 1982.

Blair, P.D.; Cassel, T.A.V.; Edelstein, R.H.; Geothermal Energy: Investment Decisions and Commerclal Development, John Wiley \& Sons, Inc., 1982.

Amundsen, C.B.; Cassel, T.A.V.; Kathan, D.W.; Federal Geothermal Royalty Income Derived From the Benefits of Government Sponsored RED, DOE/SF/11727-T1, January 1984.

See also: EER (1982)

Field Development, Electric Power Plants, Life-Cycle Costing, Market Penetration, Stochastic Analysis. 


\subsubsection{Texas Geopressured Resource Evaluation}

DEVELOPED BY: Center for Energy Studies

The University of Texas at Austin

Austin, TX

AUTHORS: $\quad J o h n$ Cornwa11, William Lesso, C. Dale Z1nn

DATES: $\quad 1979$

PURPOSE: To provide a means of evaluating alternative scenarios for developing the Texas geopressured retources under known or best estimate conditions.

ENERGY

EXTRACTION: This model takes the given reservoir characteristics of a region (thickness, permeablifty, temperature, pressure, porosity, etc.), incorporates depletion (constant percentage per year) and evaluates a lifetime flow profile for a single we11. If this flow meets minimum requirements for acceptability, the simulation then calculates a development scenario for the particular region. Based upon the maximum number of sites to be drilled, reservolr size, avallable rigs, etc., the model computes a timetable for drilling the wells. A drilling success ratio is included, and reinjection wells will be drilled if required. The cost per well drilled (for production or injection) is input by the user. Fleld operating costs are included.

ENERGY

CONVERSION: The user inputs the cost of the fuel plant and power plant directly, as well as the percentage of operating costs.

FINANCIAL PARAMETERS: The program outputs the net present value of developing the geopressured field. Inputs included are the discount rate, the selling price of methane, and the escalation factor. Taxes, depreclation, depletion allowances, and royalties are included.

COMPUTER

CODE :

Interactive. This simulation is a combination of three separate models; a reservolr model which assesses the potential of a given fairway; a development model which incorporates "hit" probabilities; and an economic analysis model.

AVAILABILITY: Unknown.

\section{REFERENCES :}

Zinn, C.D.; Operations Research and Systems Analysis of Geotherma1/Geopressured Resources in Texas, Center For Energy Studies, University of Texas at Austin, December 1977. 
Zinn, C.D.; Systems Analysis of the Texas Gulf Coast Geopressured Resources, Texas Energy Advisory Counc1l, July 1979.

Cornwa11, J. B.; Lesso, W. G.; Zinn, C. D. "The Resource Assessment, Scheduling, and Economics of Developing the Geopressured-Geothermal Resource in Texa8," Proceedings: 4th U.S. Geopressured Geothermal Energy Conference, October 1979, Pp. 1545-1575.

KEY WORDS: Geopressured Resource, Field Development, Life-Cycle Costs, Texas. 


\subsubsection{VENVAL}

DEVELOPED BY: Dupont de Nemours, Inc.

Wilmington, DE

AUTHORS: Jack Whelan, J. B. Muddiman

DATES: $\quad$ Published July 1980

PURPOSE: VENVAL is a venture analysis model developed by Du Pont, Inc. It 18 a financial cash flow tool developed to ald in the evaluetion of proposed business investments. The model is quite flexible and can be applied to a rather diverse range of ventures.

ENERGY EXTRACTION :

VENVAL does not contain physical and engineering equations and costing routines. The user inputs the costs associated with each account and their scheduling.

ENERGY

CONVERSION: See above.

FINANCIAL

PARAMETERS: In order to perform a VENVAL evaluation, a complete set of cost accounts, together with a schedule of their occurrence, and a complete set of financial parameters applicable to the part1cular venture must be available. Almost any number of cost accounts in a number of various categories can be considered. A variety of depreclation schemes and borrowing arrangements can be implemented, and a number of different economic 1 igures of merit for the project being evaluated can be generated, including internal rate of return and net present value. VENVAL provides an accounting structure with an almost endless number of posslbilities for the flow of accounts. At the user's discretion, specific relationships and options can be employed through the use of input coefficlents. The program can project 1nterrelated values of Installed capacity, production, sales revenue, operating costs, depreciation, Investment, debt, earnings, taxes, depletion, return on investment, and other cash flow measures. It can also compute related public sector and other external costs and revenues. Each case computed may have up to 50 years of venture 11fe. The user has a cholce of several hundred equations for the above computations. Each calculation may use any equation any number of times and values can be automatically escalated from year to year. It 18 also possible to perform risk analyses. Cases may be run using Monte Carlo techniques to produce statistics on selected economic parameters if the appropriate inputs have been entered in the form of probability distributions. 
COMPUTER

CODE :

Proprietary.

AVAILABILITY: VENVAL is a proprietary model developed by DuPont.

REFERENCES :

Whelan, J.; Muddiman, J. B. Synfuels Program Analysis, Volume II: VENVAL User's Manual, DOE/RA/00001-T5, Volume 2, July 1980.

Z1man, Mtchael G.; Rosenberg, L. S. "A Comparison of Economic Evaluation Models as Applied to Geothermal Energy," Energy (Oxford); 8:

No. 10 pp. 797-811 (October 1983).

See also: EER (1982)

KEY WORDS: Life-Cycle Costing, Stochastic Analysis. 


\subsubsection{WELCST}

DEVELOPED BY: METREK DIVIsion

The Mitre Corporation

McLean, VA

AUTHORS: $\quad$ Daniel Entingh, Al Lopez

DATES: $\quad$ Published February 1979

PURPOSE: This program provides a vehicle to calculate the cost of driling geothermal wells and to estimate the potential benefits of technology improvements on total cost.

ENERGY

EXTRACTION: The model does not simulate a geothermal reservolr, it is $11 \mathrm{mlt}$ ted to calculating the cost of drilling and completing a geothermal well. Activities considered are: site preparation, rig up, rig down, drilling, tripping plpe, running casing, cementing, logging, and spent fluld disposal. The user selects from 10 typical drilling/casing designs, or can enter a new design. Downhole motors, surface equipment, production well head, and dri11 bit characteristics are incorporated into the program. The frequency and costs of major drilling accidents are included in the total well costs. Depth, temperature, and rock hardness are the physical parameters considered. The costs are determined for each activity, service, equipment, and purchase based on literature reviews and surveys of drilling personel. The resultant output 1s the cost of drilling a single well.

ENERGY

CONVERSION: This is not considered in this model.

PINANCIAL

PARAMETERS: The output of the program is a one-time cost for drilling a given well

COMPUTER

CODE :

The program is written in FORTRAN. It is not interactive. The user has the option of altering 86 engineering and cost parameters to study the economic Impacts of new technology.

AVAILABILITY: The computer code is included in Reference 1.

REFERENCES :

Entingh, D.J.; Lopez, A. WELCST: Engineering Cost Model of Geothermal

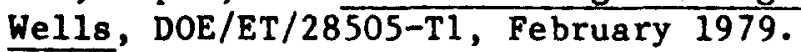

KRY WORDS: Well costs. R\&D benefits. 


\subsection{Other Models}

The following is a list of models which have been identified, but were determined to be outside the goals of this assessment.

1) BIGMAC: This model was developed by JHU/APL and has been incorporated into GRITS, version 9.

2) DSM: Developed by JHU/APL. It was incorporated into BIGMAC.

3) GEOBEN: Th1s was a software program, developed by Mitre Corporation, which took the output of WELCST and GELCOM, and projected the results of these programs in terms of the DOE Geothermal Program's 20 year development scenario (1979-1999). It was never actually formulated and documented as an independent computer model.

4) GEODRL: This mode1, developed by the BDM Corporation, forecasts geothermal well drilling activity to the year 2000. The computations are based on historical drilling data and known reservolr parameters. The economic influences or impacts are not considered.

5) GEOWELL: This model was developed by Los Alamos in the early 1970's under sponsorship of the NSF. It was a very detalled drilling cost model specifically designed for the Subterrene drilling system. Because of 1 ts limited applicablity and age, it has been omitted from detailed description.

6) GREES: An economic model written at JHU/APL, it has been incorporated into GRITS.

7) GTCOST: This was a preliminary model written at JHU/APL. It was 1ncorporated into GREES.

\subsection{Summary}

There is a substantial range of applications of the existing geothermal economic models which have been developed. These models are potentially powerful tools for work Involving design, feasibility studies, project costing, or R\&D planning. The major drawbacks assoclated with the various models are:

(1) The costing equations and default values are dated to the time of model development. This can be overruled if the user has access to actual cost estimates for the project being considered.

(2) Only four of the models (GEOCOST, GEOCOST-BC, GEOCITY, GCFM) are available through software distribution centers. The user interested in any of the other modes would be required to put forth substantial effort to obtain and 
activate the models.

\subsection{Genera1 References}

The references associated with each individual model are listed separately under the specific headings in the model abstracts. The following is a $118 \mathrm{t}$ of publications of studies which have performed comparative analyses of different mode1s.

E1-Sawy, A.H.; Leigh, J.G; Trehan, R.K.; A Comparative Analysis of Energy Costing Methodologies, MITRE Corporation, Technical Report MTR-7689, February 1979.

Engineering and Economics Research, Integrationo of Hydrothermal Energy Economics Related Quant1tative Studies, October, 1982 .

Z1man, M.G.; Rosenberg, L.S.; "A Comparison of Economic Evaluation Models as Applied to Geothermal Energy," Energy (Oxford); 8: No. 10, pp. 797-811, (1983).

Reistad, G.M.; Lawrence, T.; Geothermal District Heat1ng Mode1s: A Review of Comaptibility and Validity, Oregon State University, January 1983. 
3.0 ASSESSMENT OF COMPUTER MODELS OF GEOTHERMAL HEAT AND FLUID FLOW by RIchard McKenna

\subsection{Introduction}

Over the past decade, the level of Interest in geothermal energy development has steadily increased, and this 18 reflected In increased levels of federal and private sector activities in geothermal energy research, development and production. One area which has seen considerable effort 18 the development of computerized models of geothermal processes and systems, and it is this toplc with which th1s report 18 concerned. In recent years, the Department of Energy has sponsored the development of many such models. This document was prepared for the purpose of cataloguing these models and serving as a ready reference of basic Information on model operation, inputs, outputs and availability. In the event that future modeling activities may be undertaken, this information will provide a useful reference to past efforts. In addition, the catalogue should serve to Inform potential users of the varlety of geothermal models available, what the models do, how they do $1 t$, and how specific models can be obtained for use.

The number of geothermal models extant 18 quite large and, consequently, several restrictions were applied in order to narrow the scope of the cataloguing effort. Of primary interest are those models produced under DOE sponsorship and developed specifically for simulating physical systems and processes directly assoclated with geothermal energy development. Models developed by other public agencies (such as the U.S. Geological Survey) are thus excluded, as are privately developed models. Also excluded are models which, although applicable to geothermal systems, were not developed specifically for geothermal energy purposes. Examples of these are the subsurface heat and fluid flow models, sponsored by the DOE Ofilce of Waste Isolation, for application to the study of radionucleide transport related to subsurface alsposa. of nuslear wastes. 
The term "mode1" can be applied to a variety of technques or methodologies employed to visualize, describe, simulate or quantify the unseen characteristics of, or processes and interactions within, a subsurface geothermal system. The models discussed herein are limited to computerlzed numerical models which, through the solution of a set of mathematical equations which describe the physical processes and Interactions occurring in the system, produce a slmulated sequence of these processes and interactions over time (e.g., fluid flow and heat flux) which closely resembles the actual activity of the physical system. Not included in this report are empirical or curve fitting techniques, conceptual models or analytical solutions to equations describing physical processes, or analog or physical models of geothermal systems.

In the course of the information search conducted for this report, many models were Identified which fall into the excluded categories noted above. The Annotated Bibllography at the end of this report lists the appropriate literature citations and indicates the reason for exclusion. Additionally, several documents were identified which provide useful comparative discussions of a number of simulation models - Including some of the DOE-sponsored models contained herein, as well as models produced by other public agencles, proprietary privately developed models, curvefitting and empirical mode1s, etc. These publications are listed In the References section.

\subsection{Comparative Discussion}

Models of physical geothermal systems can be broadly classified into four types. Reservolr defintion models are used in geothermal prospecting and exploration. These take Input from geothermal surveys, such as magnetotelluric or electrical resistivity data, and provide the prospector with an Interpretation of the extent and character of subsurface reservolrs and formations. Geochemistry models rely on input describing subsurface chemical 
and physical characteristics to simulate the chemical interactions occurring between geothermal fluids and the surrounding soll or rock matrix. Wellbore and reservoir models are generally concerned with the simulation of fluid and/or thermal fluxes through the wellbore or within the reservoir.

A review of the models in all four categorles is beyond the scope of the current report, and only the latter two categories are examined here. In fact, these two types of models are sufficlently simllar to one another, and sufficient1y dissimflar to the geochemistry and reservolr definition models, to warrant their separate treatment. Both the wellbore and reservolr models involve the simulation of thermal and/or fluid flows. Frequently, a wellbore model will have some capability of simulating reservolr flow to the wellbore and, similarly, a reservolr model may be capable of simulating flow up a wellbore. Reservolr definition and geochemistry models, on the other hand, are designed for entirely different applications, have different input requirements and produce a different form of output information. For these reasons, reservoir definition and geochem1stry models are not examined here, though these may be the focus of a future cataloguing effort.

\subsubsection{Wellbore Models}

Five models are identified for simulating conditions within a wellbore drilled into a geothermal resource and these are identified, along with pertinent characteristics, In Tables 1 and 2. Generally, the wellbore itself is modeled at a constant diameter over 1 ts entire depth, although GEOTEMP2 and DEGEOWEL can provide for varlable well diameters at specified depths. All of the models are capable of providing wellbore thermal profiles, and the three models which have provisions for simulating interactions between the wellbore and the surrounding geologic matr1x (GEOTEMP2, IFDM and WELBORE) will also provide temperature profiles at radial positions around the wellbore.

Fluid flow through the wellbore can be slmulated, to a greater or lesser 
1ade 4: General physical Model informaltus

Model Name

Wellbore Models

GEOTEMP2

IFDM

GEOFLO

WELBORE

DEGEOWEL

o

\section{Where Developed}

Enertech Engineering \& Research

Petroleum Training \& Technical Service, Repub11c Geothermal Inc.

Brown University

Lawrence Berkeley Laboratory

Denver Research Institute, Coury \& Associates

\section{Reservolr Models}

\section{TERZAGI}

VARFLOW

ANALYZE

SHAFT79

CCC
Lawrence Berkeley Laboratory

Lawrence Berkeley Laboratory

Lawrence Berkeley Laboratory

Lawrence Berkeley Laboratory

Lawrence Berkeley Laboratory
Year Released

1982

1980

1981

1980

1982

1980

1982

1980

1980

1980
Qual1ty of Avallability*

Documentation
Good

Fa1r

Fa1r

Good

Poor

Good

Good

Good

Good

* 1 = Available only as a printed program listing

2 = Obtainable on magnetic tape

3 = Magnetic tape and full documentation avallable from the National Energy Software Center 
Table 5: Physlcal Mode1 Characteristics (Continued)

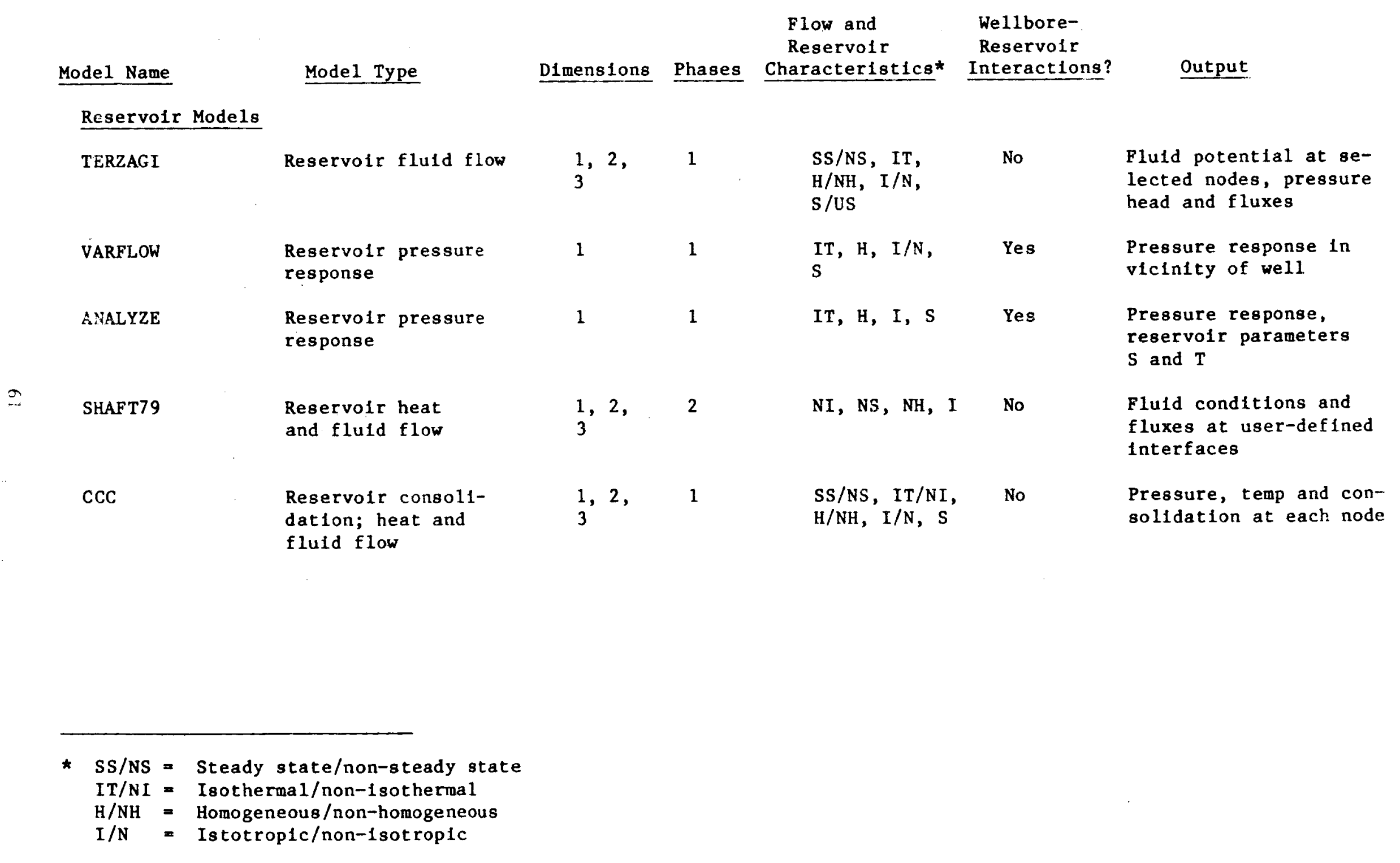


Table 5: Physical Model Characteristics

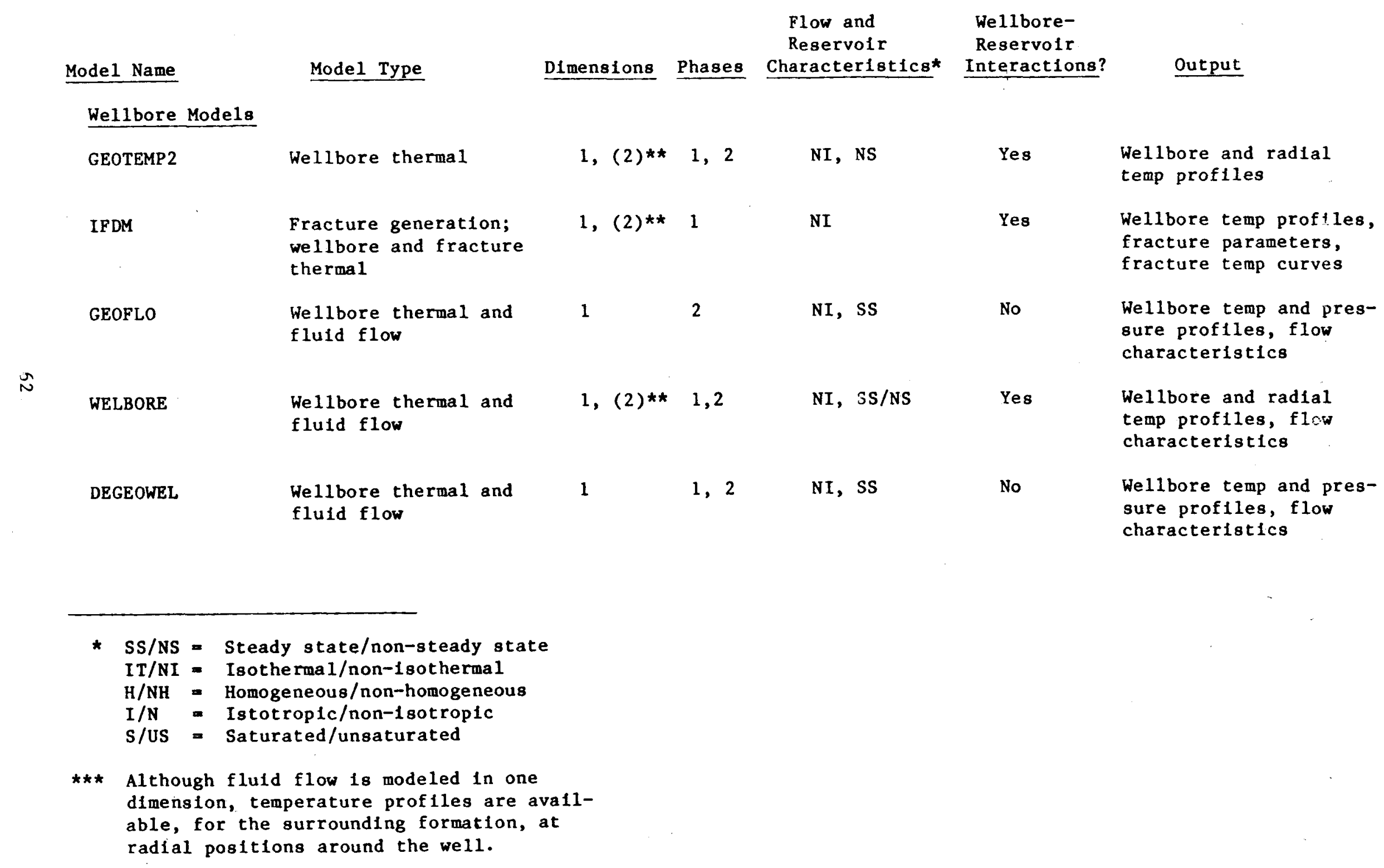


extent, by all of these models. Only WELBORE, however, has been directly coupled to a reservolr flow model to allow a complete slmulation of geothermal production fluid flow rates and properties through the reservolr, through the wellbore and to the wellhead. Fluid flow simulation in the other models (fracture fluids in IFDM, geothermal production fluids in DEGEOWEL and GEOFLO, and drilling fluids and/or production/infection flulds in GEOTEMP2) generally requires that flow rates through the well be input by the model user. With flow rates thus known, output consists of fluid properties such as pressure, quality, flow structure, density and viscosity. Two-phase fluid flow can be handled by all models except IFDM. Since all of these models include the ability to produce wellbore temperature profiles, in-well conditions are naturally modeled as belng non-1sothermal. Only GEOTEMP2 and WELBORE are capable of modeling the non-steady state flow case; all the others are restricted to steady state simulation.

As is evident from the above discussion, these five models are at once both similar and dissimflar; while sharing many characteristics, each has its own attributes and may be best sulted to particular simulation problems. The IFDM model was specifically intended for use in the design of fracture stimulation treatments for geothermal reservolrs. By modeling the temperature of the fracture fluld, its temperature-dependent physical properties can be calculated and used to generate a more realistlc fracture design. As noted earlier, the WELBORE model is unusual (and, perhaps, all the more usefu1) in the fact that it is directly linked to a reservoir flow model and can thus be used to simulate an entire geothermal production system. DEGEOWEL has the ability to model the effects of dissolved solids and gases on fluld flow rates and properties; it is the only one of these models with this feature. GEOTEMP2 is perhaps the most versatile of the wellbore thermal simulators insofar as 1 t is reportedly capable of handling multiple fluids in the wellbore, air, nitrogen or mist drilling, 
and many other complexities. It is therefore important that careful consideration be given to the technical problem to be addressed when selecting a simulation model, In order to achleve a match between user needs and model capabilities.

Each of the five wellbore simulation models discussed here is individually summarized in greater detall in the Model Summarles section of this report. Included in the summaries is a list of references from which additional published Information on each model can be obtained, an Indication of where the model can be found and how it may be acquired, and an information contact who can provide additional detalls of the models' operation and potential uses.

\subsubsection{Reservoir Models}

Five additional models are identified in Tables. 1 and 2 as being reservolr heat and fluid flow models. Lawrence Berkeley Laboratory (LBL) has been the focal point for DOE-sponsored research into geothermal reservoir flow simulation, and all of these models were developed either by LBL sclentists or through subcontracts let by the Laboratory.

Only two of these models, SHAFT79 and CCC, have the capability to simulate both heat and fluid fluxes through a geothermal reservolr. These models operate by solving coupled mass- and energy-balance equations using integrated finite difference techniques. Both of these codes treat the reservoir threedimensionally, but neither one provides a direct linkage to a geothermal production well. While the CCC model is restricted to single-phase fluld flow, SHAFT79 is capable of two-phase fluid modeling. In fact, SHAFT79 is the only one of the five reservolr models with this ability. Both models provide, as output, fluid and thermal fluxes at user-specifled interfaces within the reservolr. CCC, however, has the additional capability of modeling the onedimensional consolidation of a reservoir subjected to geothermal fluld production. 
of the remsining models, only TERZAGI models fluld flows through a three-dimensional reservolr. The fluid is modeled as isothermal, however, so thermal fluxes cannot be simulated. TERZAGI is a very general model in the sense that reservolr properties may be homogenous or non-homogeneous, 1sotroplc or non-1sotrop1c; the reservolr may be saturated or unsaturated (using an associated program, TRUST, from which TERZAGI 18 derived), and the fluid flow regime may be steady state or non-steady state. Although wellbore storage effects can be included as part of the reservolr flow simulation, TERZAGI does not include a wellbore flow simulation component.

VARFLOW and ANALYZE, the remaining two programs, are somewhat different in nature from the other programs discussed here. These are identified in Table 2 as having the capability of linking reservoir and wellbore fluid flow interactions. Both programs take input in the form of flow histories from a number of production and/or injection wells. VARFLOW also requires input values of the reservoir parameters of storativity and transmissivity. Using these data, VARFLOW simulates the reservolr response to geothermal production/injection and calculates the resulting pressure distributions in the vicinity of each specified well. ANALYZE takes a somewhat opposite approach. It, too, requires production/injection flow histories and has the additional input requirement of observed drawdown (pressure response) at a number of observation wells. Then, using estimated values of reservoir storativity and transmissivity, the model produces a set of simulated pressure responses. This simulation process is repeated in an iterative fashion, with the model constantly revising the storativity and transmissivity parameters, until a good match is obtained between the observed and simulated pressure responses. The model then returns the reservolr parameters whlch produced this match.

As with the wellbore models discussed in the previous section, considerable variety in structure and purpose $i$ seen in the reservoir models dis- 
cussed here. Again, the need for careful consideration of the needs at hand should be emphasized when selecting a model for problem simulation. It should also be noted that simulation models are of ten developed for very specific applications and, often, with very site-specific data. For this reason, some models may not be general enough for easy transferral and application to other problems or sites.

A more detailed discussion of model operations, input requirements and output data, model availability and sources of additional information is presented for each of these simulators in the Model Summaries section of this report.

\subsection{Mode1 Descriptions}

The following subsections provide a synthesis of each of the assessed wellbore and reservoir models. Each model description 18 presented in a standard format for comparison. Parameters addressed in the description include general information about the model's developer(s), an overall description of the model, Input/output parameters, computer code description, a statement on avallability, and a reference 11 st. 


\subsubsection{GEOTEMP2}

MODEL TYPE: Wellbore thermal simulator

DEVELOPED BY: Enertech Englneering and Research Co.

2600 S.W. Freeway, Sulte 300

Houston, TX 77098

CONTRACT: Sand1a Laboratories contract 46-5670, for the U.S. Department of Energy under contract DE-AC04-76DP00789

AUTHOR(S): $\quad$ Robert F. Mitchell

INFORMATION CONTACT :

Leonard Duda

Sandia National Laboratory

Albequerque, NM 87185

MODEL

DESCRIPTION: The mafor technical features and capabilities of GEOTEMP2

include the following:

1. The flowing stream energy balance is fully transient, that 18, temperature predictions are accurate for short time intervals. The thermal analysis is not "steady state."

2. The thermal properties of the wellbore are fully described, including the steel, cement, and fluids in real well completions. The program is sufficiently general to describe most wells.

3. The temperature calculations in the wellbore and the surroundiag formation are directly coupled.

4. The code has been designed with enough flexibility so that the complete life of a well from drilling to production, shut-ins for workovers, injection, etc. can be simulated in one computer run.

5. Several different wellbore fluids can be spectfled, such as drilling muds, packer fluids, cements, and production fluids. Further, more than one fluid may be 1 n the wellbore at the same time, and the displacement of one fluid by another is automatically determined.

6. Two-phase steam production and injection can be slmulated with GEOTEMP2. Flowing stream properties and flow types (e.g. slug flow) are determined as well as flow temperatures.

GEOTEMP2 is a wellbore thermal simulator designed for geothermal well drilling and production problems. It is an extensively modifled version of a previous model called GEOTEMP (Reference 4). Principal 1mprovements incorporated into GEOTEMP2 include the ability to consider: var:abl: thbin; flow areas; multiple fluids in the wellbore; deviated wellbore; air or nitrogen drilling; mist drilling; and two-phase steam productioninjection. 67 
7. Afr, nitrogen, and mist drilling can be simulated. GEOTEMP2 can swttch between alr and mud drflling at any time desired.

A ma for part of the GEOTEMP2 wellbore thermal stmulator 1 s the gas drilling/mist drilling capability. Previously, one of the few models available for gas drilling applications was that developed by $R$. R. Angel in the 1950's. The GEOTEMP2 gas drilling simulator goes far beyond previously avallable analyses by including a balance of aerodynamic drag and buoyancy forces on the cuttings, a fully described bottom hole assembly, and the effects of mist addition and water influx.

The other major component of GEOTEMP2 is the two-phase steam injection and production mode1. The empirical flow correlations used to develop the flow model were based on the Ork1szewsk1 vertical two-phase flow equations. These correlations are based on fleld data from over 200 wells and have been further verifled by other measurements. The accuracy of the model is consldered to be better than $10 \%$. The stean thermodynamic correlations use the equations of state published by Keenan and Keyes in their current edition of steam tables.

Sandia National Laboratory (SNL) reports that GEOTEMP2 has recent$1 y$ been undergoing considerable revision to correct computational defictencles and other problems with the program code. SNL does not recommend use of the model in its current state and also advises that program documentation given in References 2 and 3 is now obsolete. Revisions and corrections have recently been completed at SNL and the revised model will be avallable through the National Energy Software Center late in 1984.

INPUT DATA: The data required to fully describe a GEOTEMP2 problem include the following: tubing and casing interval depths and diameters; wellbore total depth, true vertical depth, depth of deviation, and maxtmum hole dlameter; surface, bottom hole and litermediate depth temperatures; drilling fluid densities, plastic viscosities, and yleld points.

OUTPUT DATA: The ouput from GEOTEMP2 is a temperature profile (temperature vs. depth) of the production/injection fluid in the wellbore at user-specifled times and flow rates. Temperature profiles are also given for five radial positions: the tubing and annulus temperatures, the first two formation temperatures, and the undisturbed temperature. All temperatures are given at depth increments of 200 feet.

COMPUTER

CODE :
GEOTEMP2 has been written in FORTRAN IV. Efforts have been made to keep the programming as conventional as possible so that GEOTEMP2 w111 run without modification on most computers. GEOTEMP 2 was developed on a Prine 550 inini-computer, and clearly should run on most mainframe computers. Smaller 16 bit mint and micro computers probably wlll not be sultable because of the pro- 
gram'a size.

AVAILABILITY: The revised version of GEOTEMP2 and approprlate documentation will be avallable from the Natlonal Energy Software Center late in 1984. Further detalls can be obtalned from the Information Contact Identifled above.

SELECTED REFERENCES:

1. Mitchel1, R. F., 1982. Advanced Wellbore Thermal Simulator GEOTEMP2 Research Report. Sandia National Laboratorles, report SAND 82-7003/1. Prepared under Sandia contract 46-5760 for the U.S. Department of Energy under contract DE-AC04-76DP00789, 79p.

2. Mitchel1, R. F., 1982. Advanced Wellbore Thermal Simulator GEOTEMP2 User Manual. Sandia National Laboratories, report SAND 82-7003/2. Prepared under Sandia contract 46-5760 for the U.S. Department of Energy under contract DE-AC04-76DP00789, 92p.

3. Mitchel1, R. F., 1982. Advanced Nellbore Thermal Simulator GEOTEMP2 Appendix: Computer Program Listing. Sandia National Laboratories, report SAND 82-7003/Appendix. Prepared under Sandia contract 46-5760 for the U.S. Department of Energy under contract DE-AC04-76DP00789, 98p.

4. Wooley, G. R., 1978. Wellbore and Soll Thermal Simulation for Geothermal Wells - Development of a Computer Model and Acquisition of Field Temperature Data. Sandia National Laboratories report prepared under contract 13-0212. 


\subsubsection{Interactive Fracture Design Model}

MODEL TYPE: Fracture stimulation treatment design model

DEVELOPED BY: Petroleum Tralning and Technical Services

Norinan, OK

and

Republic Geothermal, Inc.

11823 E. Slauson Avenue, Sulte 1

Santa Fe Springs, CA 90670

CONTRACT: U.S. Department of Energy contract DE-AC32-79AL10563

AUTHOR(S): $\quad$ Unidentified

INFORMATION

CONTACT :

Charles Morris Schlamberger

MODEL

DESCRIPTION: The Interactive Fracture Design Model (IFDM) can be used to design a fracture stimulation treatment for geothermal reservoirs. Because of the high temperature associated with geothermal reservolrs, standard isothermal calculations of fracture geometry inadequately describe fracturing in these reservolrs. The IFDM, however, calculates the temperature of the fracture fluld as a function of time and distance in the fracture. This information is used to determine the temperature dependent properties of the fracture fluid, and these fluld properties are utllized to calculate the fracture geometry as a function of time. The model thus allows for more realistic evaluation of various design parameters than could be obtalned from isothermal estimations.

The IDFM consists of three distinct yet integrated subprograms: (1) A wellbore thermal simulator which computes the temperature profile within the wellbore. An existing program (WELTEM) developed by Romero-Juarez (Reference 4) is used to calculate the temperature profile within the flowing stream and to allow the determination of sand-face viscosity of the fracture fluid--which is important for realistic fracture design. (2) A fracture generation model which calculates the fracture parameters (width, length, volume) based on user-supplied design input and the input recelved from the wellbore model. (3) A fracture fluid heat transfer program which determines the viscosity of the fluid in the fracture by modeling its temperature over time. Two options are avallable here. The sinclalr temperature model (Reference 2) can be used to simulate a constant "leak-off rate," or thermal flux, with time and distance; or the WhitsittDysart model (Reference 3) can be used for the varlable leak-off rate case. Both options will consider both conduction and convection heat losses.

INPUT DATA: A great deal of physical data is required to describe the reservoir (temperature, pressure, geothermal gradient), the wellbore 
(surface and bottom hole temperatures, depth, tubing and casing diameters), the fracture fluid (type, injection rate, viscosity, specific heat, volumetric heat capacity, thermal conductivity, Initial temperature), and the surrounding formation (rock shear modulus, fracture helght, volumetric heat capacity, thermal conductivity, porosity, permeability, rock density).

OUTPUT DATA: The wellbore thermal simulator subprogram gives, as output, time dependent temperature profiles in the wellbore. The fracture generation program gives the fracture parameters--width, length, volume and efficlency--as well as fracture fluid temperature as a function of time. The fracture fluid heat transfer program produces famlles of curves ( $t$ ime dependent) for fracture fluid temperature and viscosity as a function of distance in the fracture.

COMPUTER CODE :

The Interactive Fracture Design Model is written in FORTRAN IV and can be run either interactively or batch. For interactive execution, a CRT terminal with plotting capabilities is required. For batch runs, the plotted output can be spooled to a CALCOMP or similar plotting device. The load module requires $128 \mathrm{~K}$ storage to execute.

AVAILABILITY: The complete FORTRAN code listing is avallable as Appendix $C$ in Reference 1 below. Limited coples of the program on magnetic tape may be obtalned from Repubilc Geothermal. Further details are avallable from the information contact identifled above.

1. Petroleum Training and Technical Services, 1980. Interactive Fracture Design Model. Prepared by PTTS, Republic Geothermal, Inc., Sante Fe Springs, CA, for the U.S. Department of Energy under contract DE-AC32-79AL10563. Publication DOE/AL/ 10563-T4, 87p.

2. Sincla1r, A. R., 1971. Heat Transfer Effects in Deep Well Fracturing. Journal of Petroleum Technology, December 1971, p. 1484-1492.

3. Whitsttt, N.F., and G. R. Dysart, 1970. The Effect of Temperature on Stimulation Desizn. Journal of Petroleum Technology, Apr11 1970, p. 493-502.

4. Romero-Juarez, A., 1979. A Simplified Method for Calculating Temperature Changes in Deep Wells. Journal of Petroleum Technology, June 1979, p. 763-768. 


\subsubsection{GEOFLO}

MODEL TYPE: Wellbore thermodynamics model

DEVELOPED BY: Division of Engineering

Brown University

Providence, R.I.

CONTRACT: U.S. Department of Energy contract DE-AC02-79ET27225,

LASL 4-X60-6306P-1

AUTHOR(S): Z. Billck1, J. Kest1n, E.E. Michaelides

INFORMATION

CONTACT :

2. Bi11cki (Brown University)

MODEL

DESCRIPTION: GEOFLO provides a simulation of the thermodynamic properties of steady, one-dimensional, two-phase flow in a wellbore. The most essential characteristic of the model is its ability to adjust the void fraction in the flowing stream according to the flow pattern, and to keep track of the changes in the structure of the flow through the wellbore. The model can thus be used to calculate the thermodynamic properties of any two-phase vertical flow.

Further assumptions which govern the modeling of the flowing stream include: (1) the liquid and vapor phases are in thermodynamic equilibrium; (2) when flow becomes two-phase, above the flashing point, the sequence of flow structures is limited to bubbly flow $\rightarrow$ slug flow $\rightarrow->$ froth flow $-\rightarrow$ annular-mist flow; (3) each transition is described by a characteristic criterion, determined internally by the model, and the vold fraction of each flow structure is described by a characteristic correlation, also determined internally by the model; and (4) the vold fraction varies along the wellbore as a smooth function of depth, so there is no jump in vold fraction at a flow structure boundary.

INPUT DATA: Input data to GEOFLO includes the well flow rate, bottom hole temperature and static pressure, and the depth and diameter of the well. A drawdawn factor and the molality of the brine solution must also be provided.

OUTPUT DATA: GEOFLO calculates the temperature and pressure gradients along the wellbore. The depths of phase and flow structure transitions are determined and, for these depths, GEOFLO prints the temperature, pressure, quality and vold fraction of the flowing stream. At the wellhead, GEOFLO also gives the temperature, pressure, quality and vold fraction, along with the ratio of pressure drop and the mass flow rates for both the 11quid and vapor phases. 
COMPUTER

CODE :

GEOFLO has been written In both Hewlett-Packard BASIC and FORTRAN IV.

AVAILABILITY: Both the H-P BASIC and FORTRAN program listings are provided as Appendix A of Reference 1 below.

SELECTED REFERENCES :

1. Bilicki, Z., J. Kestin and E.E. Michaelides, 1981. Flow in Geothermal Wells: Part III, Calculation Model for Self-Flowing We11. Division of Engl neering, Brown University, report GEOFLO/5. Prepared for the U.S. Department of Energy under contract DE-AC02-79ET27225, LASL 4-X60-6306P-1. Publication DOE/ET/27225-8. 83p. 


\subsubsection{WELBORE}

MODEL TYPE: Wellbote fluid and heat flow model

DEVELOPED BY: Earth Sclences Division

Lawrence Berkeley Laboratory

University of California

Berkeley, CA 94720

CONTRACT: U.S. Department of Energy contract W-7405-ENG-48

AUTHOR(S): $\quad$ Constance W. Miller

INFORMATION

CONTACT :

Constance W. Miller

Berkeley Group, Inc.

2000 Center Street, Suite 302

Berkeley, CA 94704

MODEL

DESCRIPTION: WELBORE is a computer code for simulating transient, one-dimensional two-phase or single-phase non-isothermal fluid flow in a wellbore. The program uses a partially lmplicit method to solve the finite difference approximation of the Navier-Stokes equations of mass, momentum, and energy conservation. Terms that would impose a severe time restriction, such as the compressibility terms, are evaluated implicttly whlle other terms are expressed in an explicit manner. The convection effects are represented with a conserving upwind finite difference. Both the slip between the phases (when the flow 1s two-phase) and the frlctional losses are given as empirical correlations. The primary thermodynamic varlables used in solving the equations are the pressure and specific energy. An equation of state subroutine provides the density, quality, and temperature. The heat loss out of the wellbore is calculated by solving a radial diffusion equation for the temperature changes outside the bore. The calculation is done at each node point in the wellbore. The code has been coupled with a single phase radial flow reservolr model, and a version of the wellbore code coupled with a two-phase reservolr model was also developed (Reference 2 ).

The Important difference between this program and other reported wellbore models 18 that a steady state 18 not assumed, $1 . e$. , the mass into the well does not necessarily equal the mass out of 1t. Nevertheless, a steady state solution can be obtained. The translent wellbore model, with or whout the reservolr model, is useful in understanding well test results. The response of the fluid in the well can be ellminated in the analysis of well test data, 1.e., glven the wellhead flow rate or well head pressure and the downhole pressure, the sandface flow rate can be calculated. By knowlng the actual reservoir flow, reservolr properties can be determined by using a variable well test analysis technique to reduce the transient pressure data. Also, one can solve for the flow 1 in the bore during a complete shut-in to 
determine the ef rects of phase redistribution, which is not possible with a steady state model.

The heat loss out of the wellbore is a function of time. For each nodal point defined in the well, the temperature change in the surrounding rock is calculated by solving a finite difference approximation of the radial conduction equation, using a constant linear thermal gradient which is provided as input. The temperature in the rock 18 solved as a function of depth and radial position.

The single phase reservolr model provided with the program solves a finite difference approximation of the radial pressure diffusion equation using a variable grid as in the rock temperature calculation. The linking between the reservolr calculations and the wellbore calculation is done explicitly. The flow changes in the wellbore are calculated implicitly using the calculated value of the sandface reservoir pressure. Then the reservoir pressure is recalculated using the new value of the downole pressure in the well, but the old value of the reservoir pressure. The exact mass flowrate that entered the wellbore leaves the reservolr in that time step calculation.

INPUT DATA: The initial conditions needed to start a problem with WELBORE are the downhole pressure, the specific energy flowing in from the reservoli and the mass flow rate out of the well. This is sufficlent to give a steady state solution. For a transient calculation, efther the bottom hole pressure as a function of time must be known or the reservolr model can be used, keeping the pressure far from the well constant. In either case, it is necessary to provide the pressure, mass flow rate, or volume flow rate, as a function of time, at the wellhead. Other input parameters include the radius and length of the wellbore, the thermal conductivity and diffusivity of the surrounding rock, and the maximum and minimum temperatures of the geothermal grad1ent. If the reservolr model option is executed, the permeability, porosity, compressibility and thickness of the reservolr must be provided, along with the viscosity of the reservoir fluid.

OUTPUT DATA: The change in downhole and wellhead pressure is given for every other time step of the simulation. At user-specified time increments, the fluid properties in the wellbore are printed as a function of depth. These include pressure, energy, density, velocity and equilibrium density. In the case of two-phase flow, the steam and liquid velocities and the quality in place are also provided--again as a function of depth. At the same user-specified times, the temperature profile in and around the bore, as well as the reservoir pressure around the bore, are given as functions of both depth and radial position. 
COMPUTER

CODE :

WELBORE is written in FORTRAN IV and was developed on a CDC 7600 . It has also been run on the CYBER 175. 55,000 octal words of storage are required for execution.

AVAILABILITY: The WELBORE program Including the single-phase radial flow reservolr model is avallable, along with associated documentation, from the National Energy Software Center. The version of WELBORE which Includes the two phase reservolr model is obtainable from Lawrence Berkeley Laboratory.

SELECTED REFERENCES :

1. Miller, Constance W., 1980. WELBORE User's Manual. Lawrence Berkeley Laboratory report LBL-10910. Prepared for the U.S. Department of Energy under contract $W-7405-E N G-48,48 p$.

2. Mt1ler, C. W., S. Benson, M. Su11ivan and K. Pruess, 1982. Wellbore Effects on the Analysis of Two Phase Geothermal We11 Tests. Soclety of Petroleum Englneers Journa1, June 1982 . 


\subsubsection{VARFLOW}

MODEL TYPE: Reservolr pressure-response model

DEVELOPED BY: Lawrence Berkeley Laboratory

University of Callfornia

Berkeley, CA 94720

CONTRACT: U.S. Department of Energy contract DE-AC07-76ID01570

AUTHOR(S): S. M. Benson (LBL)

INFORMATION

CONTACT:

S. M. Benson

MODEL

DESCRIPTION: The VARFLOW computer program was developed to calculate the reservolr pressure response (drawdown) to geothermal production/injection. It is particularly useful in those applications where drawdowri cannot otherwise be easily calculated: where more than one well is flowing and/or brines are also being injected, or where the flow rate from a well is not held constant. VARFLOW can be used to calculate the anticipated pressure response at up to ten observation wells, due to the flows occurring at up to ten production and/or injection wells.

The 1dealized reservolr system described under the model is assumed to be of Infinite areal extent, or bounded on one side by a linear constant potential or barrier boundary, and completely saturated with a single-phase flutd, the flow of which is described by Darcy's Law. The reservolr is assumed to be horlzontal, of a constant thickness, isothermal, homogeneous and bounded above and below by impermeable layers. The reservolr permeability may be isotropic or anisotropic in the horizontal plane.

The flow into or from a fully penetrating well is unfformly distributed over the length of the well. The well is modeled as a ine source. However, a skin effect, Indicative of wellbore condition can be included in the analysis.

Flow rates from up to ten wells can vary arbitrarily. Flow rates are modeled by superposition of consecutive "production pulses." Within any "production pulse" the flow rate may be constant or vary linearly. With this scheme for modeling flow rates, any variable flow rate history can be represented to the desired accuracy by a series of sequential straight-line segments, each of the appropriate duration and Inclination.

INPUT DATA: The physical character of the reservoir is described by providing input values for reservoir transmissivity in the $x$ and $y$ directions, reservoir storativity, and the distance and azimuth (from an 
arbitrary origin) to the hydrologic boundary, and the boundary type (1.e., barrier or constant potentiai). Each of the production, infection and monttoring wells is described by providing its $x-y$ coordinates (from the same arbitrary origin) and the initial ptessure at the well priot to the start of pumping. In addition, time-flow rate data pairs must be provided for each well identifled as a production or injection well.

OUTPUT DATA: For each well specified in the input data, VARFLOW will print (at user-specified time increments) the pressure response resulting from the indicated time-flow rate regime.

COMPUTER

CODE :

VARFLOW is written in FORTRAN.

AVAILABILITY: The complete FORTRAN code is included as Appendix E in Reference 1 below.

\section{SELECTED REFERENCES:}

1. EG\&G Idaho, Inc., and Lawrence Berkeley Laboratory, 1982. Low-to-Moderate Temperature Hydrothermal Reservo1r Engineering Handbook. Geothermal Programs, Idaho Operations office, Joint Project Report of Lawrence Berkeley Laboratory and the Idaho Nat lonal Engineering Laboratory, report ID0-10099. Prepared for the U.S. Department of Energy under contract DE-AC0776ID01570. 


\subsubsection{TERZAGI}

MODEL TYPE: Reservoir fluid flow model

DEVELOPED BY: Lawrence Berkeley Laboratory

University of California

Berkeley, CA 94720

CONTRACT: U.S. Department of Energy contract W-7405-ENG-48

AUTHOR(S): $\quad$ T. N. Narasimhan

INFORMATION

CONTACT :

T. N. Narasimhan (LBL)

MODEL

DESCRIPTION: TERZAGI is an integrated finite-difference computer program which solves for transient and steady-state fluid potentials in one-, two- or three-dimensional, saturated, deformable, confined systems having isothermal flow. It is applicable to artesian aquifers or petroleum reservolrs. The system can be made up of porous or fractured materlals and can have complex geometry. The flow region can be heterogeneous, and anisotropy can be handled by orlenting surfaces of volume elements normal to principal axes of permeability. Wellbore storage effects can be included as part of the flow region. The material properties such as permeability and matrix compressibility can be functions of pressure. Boundary conditions can be functions of potential or time. The program has been applied to problems related to ground subsidence, flow in fractured rocks, and hydraulic fracturing and has been extensively validated. The program is based on the integrated finite-difference method of Narasimhan and Witherspoon (Reference 2), and uses a mixed explicit-implicit iterative technique for solving the confined system flow problem.

TERZAGI is a saturated-flow version of the more general program TRUST (TRansient flow in Unsaturated and STrained porous media) which solves for both saturated and unsaturated flow in porous media (References 3 and 4).

INPUT DATA: Reservoir geometry can be specified in one, two or three dimensions, employing rectangular, cylindrical, axial or spherical symmetry. The volumetric properties of each grid block and the geometric properties of each node connection must be input. Each grid block can be assigned a different material, and the permeability and fluid storage coefficlent of each material can either be specified as constants or calculated by the program using user-supplied functions relating these parameters to effective stress, vold ratio or coefficlent of compressibility. The water density, viscosity and compressiblitty are all required inputs, as are the volumetric fluid generation rate from sources and sirks, initial pressure head, preconsolidation stress and boundary conditions. 
OUTPUT DATA: The value of pressure head and 1 ts tine dertuative at a selected node and the pressure heads and fluxes of all the grid blocks can be output at regular time intervals or cycles. Separate graphic programs can be used to process the output data.

COMPUTER

CODE :

The computer code is written in FORTKAN IV. The program was developed on the $\mathrm{CDC} 7600$, but has been adapted to a number of computer systems. 106,000 octal words of pemory are required for execution.

AVAILABILITY: The TERZAGI model is avallable on magnetic tape from the National Energy Software Center. Program 11s Ings of the general mode1, TRUST, can be obtalned from Lawrence Berkeley Laboratory.

SELECTED REFERENCES :

1. Narasimhan, T. N., 1980. Program TERZAGI User's Manual. Lawrence Berkeley Laboratory repor: LEL-10908. Prepared for the U.S. Department of Energy under contract W-7405-ENG-48. $14 \mathrm{p}$.

2. Narasimhan, T. N. and P. A. Witherspoon, 1976. An Integrated Finite Difference Method for Analyzing Fluid Flow in Porous Media. Water Resources Research, 12:1, p.57-64.

3. Narasimhan, T. N. and P. A. Witherspoon, 1977. Numerical Model for Saturated-Unsaturated low In Deformable Porous Med1a, 1. Theory. Water Resources Research, 13:3, p657-667.

4. Narasimhan, T. N., P. A. Witherspoon and A. L. Edwards, 1978. Numerical Model for Saturated-Unsaturated Flow in Porous Media, 2. The Algorithm. Water Resources Research, $14: 2, \mathrm{p} 255-261$. 


\subsubsection{ANALYZE}

MODEL TYPE: Analysis of well interference/production

DEVELOPED BY: Lawrence Berkeley Laboratory

University of California

Berkeley, CA 94720

CONTRACT: Department of Energy contract W-7405-ENG-48

AUTHOR(S): D. McEdwards and S. M. Benson

INFORMATION

CONTACT :

S. M. Benson (LBL)

MODEL

DESCRIPTION :

ANALYZE is a history matching program designed for the analysis of both interference tests and production tests in single phase, fluld saturated, hydrothermal reservoirs. The model operates to minimize the difference between a set of measured pressure points and a set of calculated pressure points, and then returns reservolr parameters of transmissivity, storativity, and distance to a single linear reservolr boundary. The technique employed allows the simultaneous analysis of pressure from up to twenty observation wells, each influenced by the production (and/or injection) of as many as 20 wells with arbitrarily varying flow rates. An analytic solution calculates pressure responses in an isothermal, 1sotropic, homogenous, porous media of constant thickness and infinite areal extent. The production well is modeled as a fully penetrating line source. Flow in the reservoir is radial and of uniform flux over the height of the well.

The type of well test data to be analyzed may be placed in two groups: interference test data and production test data. Interference test data comprise pressure records from one or more observation wells (no dual wells) and flow data from one or more production wells (regular production wells and/or dual wells). Production test data comprise pressure attributable to the skin effect. Interference test pressure data are analyzed for global values of transmissivity, storativity, and the presence and type of hydrological boundaries (impermeable or constant potential). Production test pressure data comprise records from one or more dual wells. The skin effect and local transmisivity and storability values are sought for each dual well. The presence of a boundary may be detected in a dual well's pressure record if the duration of the test is sufficiently long.

To handle a variable flow rate, the production rate history is assumed to be adequately represented by a series of straight line segments of approprlate length and inclination. The drawdown caused by the production rate is obtained via a line source solution, and the pressure response of the series of production pulses is obtained by suming the individual responses. 
Calculated pressure responses are compared to observed responses and a non-linear least squares matching rout ne is used to minimize the difference by varying the reservoir parameters for transmissivity, storativity and the distance to a reservoir boundary. This is accomplished by starting from an intial set of parameter values and changing the parameter values in such a fashion as to iteratively reduce the value of the least squares statistic. When an acceptable minimum has been reached, the calculated pressure responses will be nearly equal to the observed responses, and the parameter values that correspond to the minimum are accepted as final results.

INPUT DATA: Required Input data for the ANALYZE program Include the $x-y$ coordinates of each observation and production well, observed pressure (for each observation well) or low (for each production wel1) sequences as a function of time, and initial estimates of reservolr transmlssivity and storativity. This core information is sufficlent to do a two-parameter ( $S$ and $T$ ) interference test analysis Involving several observation and production wells. For boundary analysis, one must also specify boundary type (barrier or constant potential) and provide initial estimates of boundary azlmuth and distance. A skin effect analysis can also be obtained by specifying the production wells of interest and providing initial skin effect values.

OUTPUT DATA: For each observation well and for each data point, ANALYZE provides the time, observed drawdown, calculated drawdown, the difference between the calculated anc osseryed drawdown, the ratio between the calculated and observed drawdown and a log-log plot of observed and calculated drawdoms versus time. The final values of the storativity and transmssivity parameters are also given; as 18 the value of the least squares statistic at the best minimum.

COMPUTER

CODE :

The program was written for use on a CDC 7600 and uses LCM. The program, however, has no unusual memory requirements. It is easily transferable to other computer systems.

AVAILABILITY: The ANALYZE program and documentation are avallable through the National Energy Sof tware Center.

\section{SELECTED REFERENCES :}

1. D. McEdwards and S.M. Benson, 1980. ANALYZE User's Manual. Lawrence Berkeley Laboratory report LBL-10907. Prepared for the U.S. Department of Energy under contract W-7405-ENG-48. $42 \mathrm{p}$. 
ZL TYPE: Reservolr fluld and heat flow model

ILOPED BY: Lawrence Berkeley Laboratory

Un1 versity of California

Berkeley, CA 94720

[RACT: U.S. Department of Energy contract W-7405-ENG-48

10R(S): K. Pruess and R. C. Schroeder

JRMATION

IACT :

K. Pruess (LBL)

:L

:RIPTION: SHAFT79 (Simultaneous Heat And Fluld Transport) is an integrated finite difference program for computing two-phase non-isothermal flow in porous media. The principal application for which SHAFT79 is designed is in geothermal reservoir simulation in one, two or three dimensions. SHAFT79 solves the same equations as an earlier version, called SHAFT78 (References 3 and 4), but uses much more efficient mathematical and numerical methods.

SHAFT79 solves coupled mass- and energy-balance equations under the following assumptions: (1) The physical systems described by SHAFT79 are approximated as systems of porous rock saturated with one-component fluid in liquid and vapor form. (2) Except for porosity, which can vary with pressure and temperature, all other rock properties (density, specific heat, thermal conductivity, absolute permeability) are independent of temperature, pressure, or vapor saturation. (3) Liquid, vapor, and rock matrix are in local thermodynamic equilibrium (i.e., at the same temperature and pressure) at all times. (4) Capillary pressure 18 neglected. Applications of SHAFT79 to fractured reservoirs are possible, using double or multiple porosity techniques (References 5 and 6 ).

The equilibrium thermodynamic properties of the fluid filling the vold space are described by way of a "fluid table," which gives all required quantities (temperature, pressure, vapor saturation, heat conductivity, liquid and vapor viscosities, densities, specific internal energies) as functions of the two principal dependent variables, which are fluid density and fluid specific internal energy. All thermodynamic information, including all derivatives, is obtained by means of bivariate interpolation from the fluid table. Such a table can be specifled for any one-component fluid, and hence SHAFT79 is capable of modeling the flow of any one-component fluid in porous rock. A fluld table which covers most of the equation of state of water substance in the temperature range $5-400^{\circ} \mathrm{C}$ and the pressure range $0.5-200$ bar, is avallable as part of the SHAFT79 program package. 
INPUT DATA: Required inputs to SHAFT79 finclude lata describing the reservoir geometry, boundary conditions (heat and mass flow, pressure and temperature conditions), composition and proper:ies of the resetvolr matrix (porosity and permeabilities, rock density, heat conductivity, and specific heat), sinks and sources of mass and heat (generation rates), and inftial conditions.

OUTPUT DATA: SHAFT79 produces, as output, a complete specification of the thermodynamic state of the fluid throughout the reservoir, and considerable information relating to instantaneous and cumulative, liquid and vapor, mass and energy, flows and balances across user-defined interfaces within the simulated reservoir.

COMPUTER

CODE :

SHAFT79 is written in FORTRAN IV and was developed on a CDC 7600. Minor modifications necessary to sult other machines are eas11y accomplished, however, and the program has been successfully installed on IBM, Burroughs and Cray systems. The program is quite large and requires 725,000 octal words of storage.

AVAILABILITY: The computer program, with associated documentation, is avallable through the National Energy Software Center.

\section{SELECTED REFERENCES :}

1. Pruess, K., and R. C. Schroeder, 1980. SHAFT79 User's Manual. Lawrence Berkeley Laboratory report LBL-10861. Prepared for the U.S. Department of Energy under contract W-7405-ENG-48. $47 \mathrm{p}$.

2. Pruess, K., and R. C. Schroeder, 1979. Geothermal Reservolr Simulation with SHAFT79. Lawrence Berkeley Laboratory report LBL-10066, presented at the Fifth Geothermal Reservoir Workshop, Stanford, CA.

3. Pruess, K., R. C. Schroeder, P. A. Witherspoon, and J. M. Zerzon, 1979. SHAFT78, a Two-Phase Multidimensional Computer Program for Geothermal Reservolr Simulation. Lawrence Berkeley Laboratory Report LBL-8264.

4. Pruess, K., J. M. Zerzan, R. C. Schroeder and P. C. Witherspoon, 1979. Description of the Three-Dimensional Two-Phase Simulator SHAFT78 for Use in Geothermal Reservolr Studies. Paper SPE-7699 presented at the Fifth Symposium on Reservolr Simulation, Denver, Co.

5. Pruess, K., and T.N. Narasinnan, 1982. On Fluid Reserves and the Production of Superheated Steam from Fractured, Vapor-Dominated Geothermal Reservolrs. Journal of Geophysical Research, Vol. 87, no. B11, p. 9329-9339.

6. Pruess, K., 1983. GMINC 
$3.3 .10 \quad \operatorname{CCC}$

MODEL TYPE: Reservolr flow, temperature and consolidation model

DEVELOPED BY: Lawrence Berkeley Laboratory

University of California

Berkeley, CA 94720

CONTRACT: U.S. Department of Energy contract W-7405-ENG-48

AUTHOR(S): M. J. Lippmann

INFORMATION

CONTACT :

M. J. Lippmann (LBL)

MODEL

DESCRIPTION: The CCC model (Conduction-Convection-Consolidation), numerically solves coupled heat- and mass-flow equations for a liquid saturated medium, and computes one-dimensional consolidation of the simulated system. The model employs the integrated finite difference method in discretizing the saturated medium and formulating the governing equations. The sets of equations are solved by an iterative solution technique in which the flow regime is divided into arbitrarilyshaped polyhedrons constructed by drawing perpendicular bisectors to lines connecting nodal points. This permits easy evaluation of the surface integrals of the mass and energy-flow equations. The deformation of the medium is calculated using the one-dimensional consolidation theory of Terzaghi.

In the development of the mathematical model used in the computer code, the following primary assumptions have been employed: (1) Darcy's law adequately describes fluid movement through fractured and porous media; (2) the rock and the fluid are in thermal equilibrium at any given time; (3) energy changes due to the fluid compressibility, acceleration and viscous dissipation are neglected; and (4) the one-dimensional consolidation theory can adequately describe the vertical deformation of the medium. Assumptions 1 to 3 are generally employed in the numerical modeling of geothermal reservoirs. The chief limitation of the method is that the finite difference gradient approximation is Inadequate in evaluating tangential gradients along the interfaces and handling tensorial properties such as the stress fields, which generally rotate with time.

INPUT DATA: The CCC program requires substantial and falrly detailed input data. Included in the data requirements are information related to: reservolr and node geometry; intitial conditions in the reservolr and at the nodes; mass flow rates between nodes; and the properties of the reservolr materials, fluid and overburden. The code allows specification of up to twelve different materials. For each material the porosity, permeability, specific storage, thermal conductivity, heat capacity and density of the solid must be specified. These parameters may be constant or may vary 
with temperature, and/or effective stress. The porosity and specific storage can vary with the effective stress, the permeabflity th both temperature and effective stress, and the thermal conductivity and heat capacity with temperatures only. These relations are specifled by tables, which are interpolated during each time step.

Input parameters for fluld properties include viscosity, heat capacity, density and compressibility of water. A constant value of the compressibility must be specified; other fluid properties may also be assumed constant. However, the code provides the option of specifying the viscosity and heat capacity as a function of temperature, and density as a function of temperature and pressure. An empirical formula is used for the density function, while the code interpolates input tables for the appropriate value of the viscosity and heat capacity during each time step.

OUTPUT DATA: Output is provided according to specified times or specified time steps. The pressure, temperature and first and second order derivatives are printed for each node, as is the total nodal pore volume reduction (consolidation). The fluid and energy fluxes are given for each node connection. The mass and the energy balance are also included in the output.

COMPUTER

CODE :

CCC is written in FORTRAN IV and was developed on the CDC 7600. Execution requires 66,000 octal words of memory.

AVAILABILITY: The code listing and documentation is avallable from Lawrence Berkeley Laboratory, or may be purchased from the National Energy Software Center.

SELECTED REFERENCES:

1. Mangold, D.C., M.J. Lippmann and G.S. Bodvarsson, 1980. CCC User's Manual. Lawrence Berkeley Laboratory report LBL-10909. Prepared for the U.S. Department of Energy under contract W-7405-ENG-48. 50p.

2. Lippmann, M.J., C.F. Tsang and P.A. Witherspoon, 1977. Analysis of the Response of Geothermal Reservolrs Under Injection and Production Procedures. Soclety of Petroleum Englneers Paper 6537, presented at the 47 th Annual California Meeting, SPE-AIME, Bakersfield, CA.

3. Mangold, D.C., C.F. Tsang, M.J. Lippmann and P.A. Witherspoon, 1979. A Study of Thermal Effects in Well Test Analysis. Lawrence Berkeley Laboratory report LBL-9769. Soclety of Petroleum Engineers Paper 8232, presented at the 54th Annual Fall Technical Conference, SPEAIME, Las Vegas, NV. 
Dudak, B., R. Galbraith, L. Hansen, D. Sverjensky and 0. Weres, 1982. Fluid Sampling and Chemfcal Modeling of Geopressured Brines Containing Methane, Final Report. Lawrence Berkeley Laboratory report LBL-12832 prepared for the U.S. Department of Energy under contract DE-AC01-76SP00098. $126 \mathrm{p}$.

Miller, I., W. Dershowitz, K. Jones, L. Myer, K. Roman and M. Schauer, 1980. Detailed Report on Tested Models, Companion Report 2 to Simulation of Geothermal Subsidence (LBL-10571). Lawrence Berkeley Laboratory report LBL-10837 prepared by Golder Associates, Seattle, WA for the U.S. Department of Energy under contract W-7405-ENG-48. 206p.

Molloy, M.W., 1980. Proceedings: Special Panel on Geothermal Model Intercomparison Study. Sixth Annual Workshop on Geothermal Reservolr Engineering, Stanford, CA, conducted for the U.S. Department of Energy under contract DE-AT03-80SFI1459, 120p.

Pinder, G.F., 1979. State-of-the-Art Review of Geothermal Reservolr Modeling. Lawrence Berkeley Laboratory Report LBL-9093 prepared by Golder Associates, Seattle, WA, for the U.S. Department of Energy under contract W-7405-ENG-48. $144 p$.

Wang, J.S.Y., C.F. Tang and R.A. Sterbentz, 1982. The State of the Art of Numerical Modeling of Thermohydrologic Flow in Fractured Rock Masses. Lawrence Berkeley Laboratory Report LBL-10524 prepared for the U.S. Deptment of Energy under contract DE-AC03-76SF00098. 243p.

Za1s, E.J., 1980. Analysis of Production Decline in Geothermal Reservolrs. Lawrence Berkeley Laboratory Report LBL-11215 prepared by E11lot Zais \& Associates, Corvallis, OR, for the U.S. Department of Energy under contract $W-7405-E N G-48$. 75p.

\subsection{Annotated Bibliography}

Acheribach, J.D., Z.P. Bazant, J. Dundurs, L.M. Keer, S. Nemat-Nasser, T. Mura and J. Weertman, 1980. Hot Dry Rock Reservoir Characterization and Modeling, Final Report. Prepared by Northwestern University Technological Institute, Evanston, IL, for the U.S. Department of Energy under contract W-7405-ENG-36. Report no. LA-8343-MS. 160p.

Note: Lab experimentation and analytical solutions.

Aydelotte, S.R., 1980. Transient Well Testing In Two-Phase Geothermal Reservoirs. Lawrence Berkeley Laboratory Report LBL-10562, prepared by Intercomp Resource Development and Engineering under subcontract 3976812, for the U.S. Department of Energy under contract W-7405-ENG-48. 139p.

Note: Application of proprietary Intercomp simulation models.

Bodvarsson, G.S., 1982. Mathematical Modeling of the Behavior of Geothermal Systems under Exploitation. Lawrence Berkeley Laboratory report LBL-13937 
prepared for the U.S. Department of Energy under contract W-7405-ENG-48. $377 \mathrm{p}$.

Note: Ph.D Thesis, involving modifications to the CCC model (see main report).

Carson, C.C., Y.T. LIn and B.J. Livesay, 1983. Representative Well Models for E1ght Geothermal Resource Areas. Sandia National Laboratory Report SAND81-2202 prepared for the U.S. Department of Energy under contract DE-AC04-76DP00789. 132p.

Note: Drilling time and cost studies of "model wells"; no simulation modeling employed.

Dedolph, R.E. and W.T. Parry. A Thermodynamic Model of the Hydrolysis of Microcline in Acid Sulfate Solutions. Prepared by the Untversity of Utah for the U.S. Energy Research and Development Administration under contract EY-76-S-07-1601. 63p.

Note: Older geochemistry code, ERDA-sponsored.

Dittman, G.L. 1977. Wellflow for Geothermal Wells: . Description of a Computer Program Including Effects of Brine Composition. Lawrence Livermore Laboratory report UCID-17473 prepared for the U.S. Energy Research and Development Administration under contract W-7405-ENG-48. 49p.

Note: Older code, ERDA-sponsored.

Energy Research and Development Administration, 1974. SIMPAC: A General PurPose Simulation Package for Fluid Flow in Porous Media and Heat Conduction in Sollds. Report TID-27323 prepared by the ERDA Morgantown Energy Research Center. 48p.

Note: Older code developed by ERDA.

MacDonald, R.C., K. Sepehrnoori and H. Ohkuma, 1982. Gulf Coast GeopressuredGeothermal Reservolr Simulation: Final Report, Year 4. Prepared by the University of Texas, Austin, Center for Energy Studies, for the U.S. Deparment of Energy under contract DE-AC08-79ET27112. Report no. DOE/ $\mathrm{ET} / 27112-3$. 96p.

Note: Does not involve simulation model development.

Michaelides, E.E., 1980. Models for Geothermal Wells. Ph.D. Thesis, Brown University, Providence, RI. Prepared for the U.S. Department of Energy under contract DE-AC02-79ET27225. Report no. DOE/ET/27225-T3. 148p.

Note: Ph.D. Thesis, involving model component development.

Miller, A.B., 1978. Brine-Steam Properties Computer Program for Geothermal Energy Calculations. Lawrence Livermore Laboratory report UCRL-52495 prepared for the U.S. Department of Enery under contract W-7405-ENG-48. 50p. 
Note: Thermodynamic properties using equations of state. Not a simulation model itself, but could be used as a subprogram in a simulation model.

Miller, D.G., A.J. Piwinskil and R. Yamauch1, 1977. Use of Geochemical Equilibruim Computer Calculations to Estimate Precipitation from Geothermal Brines. Lawrence L1 vermore Laboratory report UCRL-52197 prepared for the U.S. Energy Research and Development Administration under contract W-7405-ENG-48. 38p.

Note: Older code, ERDA-sponsored.

Rlemer, D.H., H.R., Jacobs and R.F. Boehm, n.d. Unfversity of Utah Direct Contact Geothermal Power Project Report: A Computer Program for Determining the Thermodynamic Properties of Water. Prepared by the University of Utah for the U.S. Energy Research and Development Adminfstration under contract AER-75-01039. Report no. UTEC-ME-76-171. 73p.

Note: Older code, ERDA-sponsored.

Rogers, L.A., 1980. Computer Simulation of Production from Geopressured-Geothermal Aquifiers. Prepared by the Institute of Gas Technology, Chicago, for the U.S. Department of Energy under contract DE-AC08-78ET27098. Report no. DOE/ET/27098-1. 102p.

Note: Uses proprletary Intercomp model.

Schroeder, R.C., 1976. Modeling the Temperature-Dependent Scale Accumulation from Geotherwal Brine. Lawrence Livermore Laboratory report UCRL-52145 prepared for the U.S. Energy Research and Development Administration under contract W-7405-ENG-48. 16p.

Note: Older code, ERDA-sponsored.

Sullivan, W.N., 1970. Wellbore Thermal Model. Sandia National Laboratory report SAND-75-0491 prepared for the U.S. Energy Research and Development Administration under contract $\operatorname{AT}(29-1)-789$. 22p.

Note: Older code, ERDA-sponsored.

Weare, J.H., 1981. Geothermal Brine Modeling - Prediction of Mineral Solubilities in Natural Waters: The $\mathrm{Na}-\mathrm{K}-\mathrm{Mg}-\mathrm{Ca}-\mathrm{H}-\mathrm{Cl}-\mathrm{SO}_{4}-\mathrm{OH}-\mathrm{HCO}_{3}-\mathrm{CO}_{3}-\mathrm{CO}_{2}-\mathrm{H}_{2} \mathrm{O}$ Sys tem to High Ionic Strengths at $25^{\circ} \mathrm{C}$. Prepared by the Department of Chemistry, University of Callfornia, San Diego, for the U.S. Department of Energy under contract DE-AT03-81SF11563. Report no. DOE/SF/11563-T1. 107p.

Note: Not a simulation model.

Weres, O. and R.C. Schroeder, 1978. Documentation for Program OGRE. Lawrence Berkeley Laboratory report LBL-7060 prepared for the U.S. Department of Energy under contract W-7405-ENG-48. $61 \mathrm{p}$.

Note: Grid construction program for coupling to subsurface models, not a simulation model itself. 


\subsection{ASSESSMENT OF GEOTHERMAL RELATEU DATA BASES}

by Robert E. Blackett

\subsection{Summary}

Data bases that were developed for, or in connection with DOE sponsored geothermal evaluation programs were reviewed with respect to their applicability and usefulness. Eight data bases were selected for the review based upon their potential widespread appeal and other factors. The data bases considered for this study were:

1) GEOTHERM - compiled by the U.S. Geological Survey

2) GRAD - Developed by Lawrence Berkeley Laboratory

3) GPM - Developed by Mitre Corporation, currently under direction of Meridian Corporation

4) OIT Site Data Bases - Compiled by the Oregon Institute of Technology, Geo-Heat Utilitzation Center

5) UURI Open File Data - Compiled by the University of Utah Research Institute, Earth Science Laboratory

6) UURI Sample Library - Compiled by the University of Utah Research Institute, Earth Science Laboratory

7) Leasing and Permitting Data Base - Developed by WAPORA, Inc.

8) LOGDEX Data Base - Compiled by the Unfversity of Texas at Austin.

These data bases were found to be useful for certain aspects regarding geothermal development and utilization. The results of the review are generalIzed on Table 6, and are outlined in more detall in the Data Base Catalogue.

\subsection{Introduction}

Since the Initlation of U.S. government direct Involvement in assessment and evaluation of geothermal energy resources and related technologies by the Department of Energy and predecessor agencles, data have been either generated or complled in support of the many programs. As a result of the DOE sponsored 
geothermal programs, data have been generated from research and resource assessment projects. These data, in addition to already existing information, have been the focus of still other data gathering programs that have addressed the compilation of basic resource and resource utilization related information in the form of physical, chemical, mineralogic, engineering, and institutional parameters.

The purpose of this study was to identify the data bases, and describe their avallability, scope, and usefulness. Contained in the report is a catalogue and description of various data bases that have been complled as a direct result of DOE programs. The catalogue and descriptions were compiled by obtaining program summaries and samples of the data bases from the Department of Energy Technical Information Center (TIC), the National Technical Information Service (NTIS), and the library services at the Department of Energy headquarters. Data base 11terature searches were performed through the DOE library computer services by using DOE/RECON, the Department's on-line information retrieval system. Abstracts that were obtained from the searches were then reviewed for applicability. Detailed information was then gathered on selected individual data sets.

The data sets reviewed in this report represent those data bases that have been developed for the expressed purpose of providing to users, a framework for geothermal exploration, development, and utilization. It is recognized that other data sets exist, and have localized importance. However, the focus of this study was to identify and compare those data sets that possess detalled resource related information and have broad based coverage.

Each data base summary Identifies the data base by title and presents the following information: 1) who compiled it; 2) where the data base or information concerning the data base is physically located 3) who the technical coordinators are or a central contact point of reference; 4) dates that may be relevant to the 
compilation of information, or the design of the program; 5) a general discussion of the rationale and purpose for the data base; 6) a description of the data base with regard to the parameters and physical format; 7) selected references to provide more detafled information about the data base; 8 ) a brief statement as to the current avaflability of the data base; and 9) a key word list to aid the prospective user in the search for particular data elements.

Table 6 is a matrix that compares the elements contained and relative usefulness of each data base. The name of the data base appears at the top of the matrix and corresponds to the summaries within the attached Data Base Catalogue. The Department of Energy and its predecessor agencles have maintained the Technical Information Center (TIC) in Oak Ridge, Tennessee as the national center for scientific and technical information. TIC places under bibllographtc control, worldwide 11terature on scientific and technical advances in the energy field. In addition to scientific literature, coverage is extended to DOE programmatic, socioeconomic, environmental, legislative/regulatory, energy analysis, and policy-related areas. Computer retrleval systems are used to access the bibliographic file and obtain abstracts of specified literature. The public can gain access to the Center's Energy Data Base (EDB) through various commercial on-line retrieval systems. Other government agencles, state energy agencles, DOE offices, and contractors can utilize DOE/RECON, the Department's on-1ine information retrieval system.

\subsection{Data Base Comparison}

Base by base comparison of the current usefulness of each data base is presented here. Although data files are an important source of backup information, the accessibility and "ease of use" of those files are important considerations. Detalled data base summaries are included in the appendix following the comparison. 


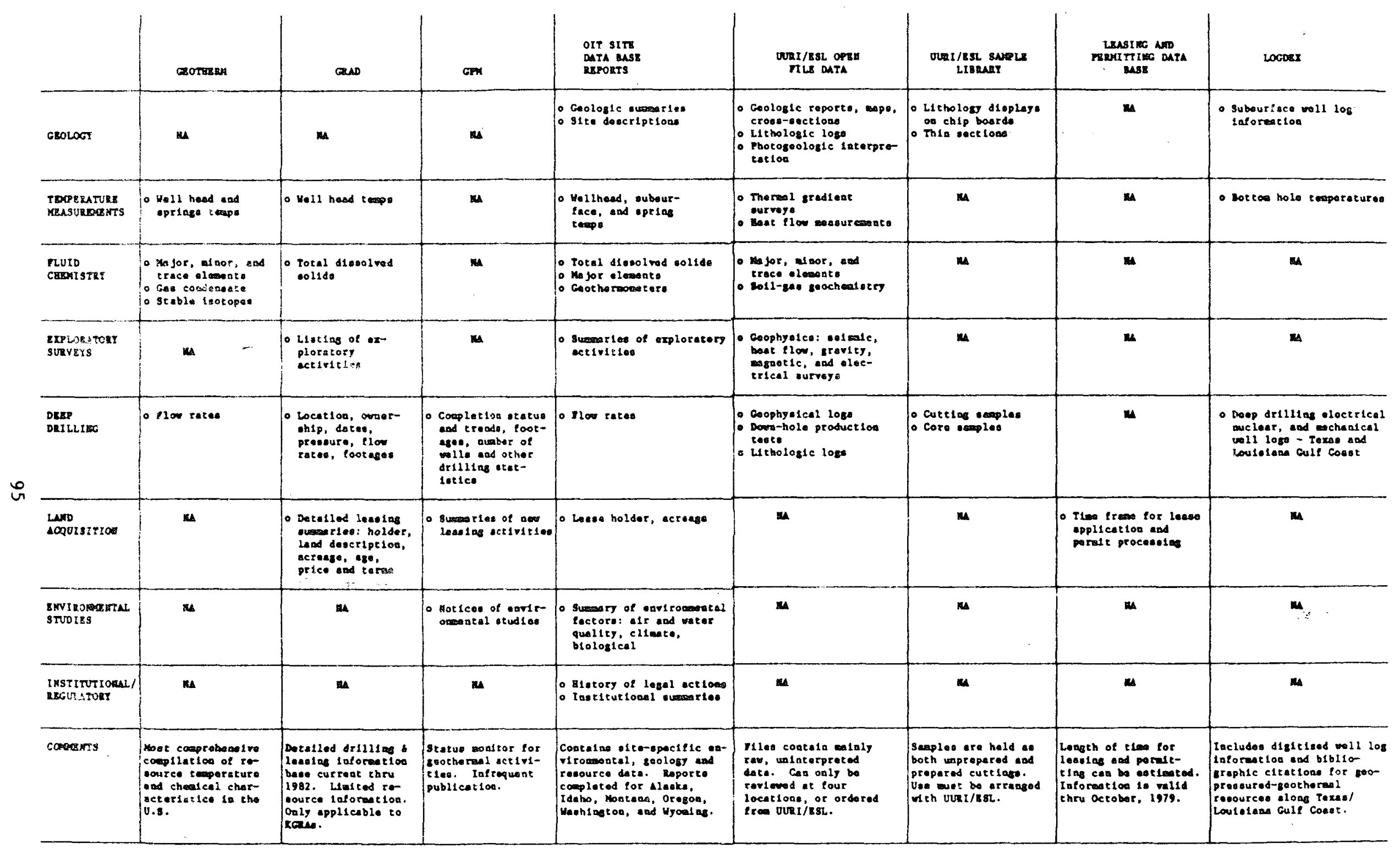




\section{GEOTHERM}

The GEOTHERM data base was colaplled by the U.S. Geological Survey and represents the most complete data set relative to an overall geothermal resource assessment of the United States. Data from GEOTHERM, which Include fluid geochemistry, stable 1sotopes, gas condensate, temperature, and production rate measurements of over 10,000 thermal wells and springs in the U.S., can be used to augment reglonal, area, and prospect-sized geothermal evaluations. Data for GEOTHERM were input unt 11 1981. The file was released for distribution in 1982. The input period covered the major portion of government sponsored resource assessment and commercialization planning prograns and therefore contain the principal set of non-proprietary data elements gathered from government/state cooperative and government/Industry cooperative programs.

GRAD

GRAD or "Geothermal Resource Areas Data base" was initiated in 1979 at Lawrence Berkeley Laboratory, as a complement to the National Geothermal Progress Monitor System. GRAD organized data from existing geothermal areas where high quality hydrothermal reservoirs had been identified and characterized through exploration programs. The data base not only includes resource characteristics, but also Incorporates financial and institutional factors. The user could interactively enter the GRAD data base through the SPIRES data management system at Stanford University and formulate status reports according to Informational needs.

GRAD maintains Information pertaining to leasing, exploration, development, powerplant siting, legal, and institutional factors.

The National Geothermal Information Resource (GRID) was a program conducted by Lawrence Berkeley Laboratory and sponsored by the U.S. Department of Energy to provide critically evaluated data and other information for the development and utilization of geothermal energy. GRID consisted of predominantly bibllographic 
information for search and retrieval using various descriptors. The project was discontinued in 1979 and succeeded by the GRAD project. Bibliographic citations from GRID covering worldwide literature sources through 1978 are avallable from NTIS.

The GRAD data base is presently off line with no data entries since late 1982. Due to the changeable character of the non-resource orlented portions of the data entries, a significant amount of updating would be necessary to make current those legal and institutional elements. Resource portions of the data base would not change significantly, but rather would need additions such as data about newly drilled wells, or geophysical surveys.

Geothermal Progress Monitor (GPM)

The GPM was Initiated in 1979 as part of the National Geothermal Progress Monftoring System. The original concept was to familiarize DOE program personnel and others with current status and events in the geothermal industry, and to meet reporting requirements. The GPM contalns information about geothermal development in the United States in the form of development statistics and current trends in the geothermal industry.

The emphasis of the GPM was inftially directed at informing DOE personnel about federally sponsored programs and tracklng the geothermal industry "pulse". Recent changes in GPM reporting will shift the emphasis more toward informing Industry and other sectors about Department of Energy RD\&D activities and information dissemination programs.

\section{UURI/ESL Open F1le Data}

The Industry Coupled Case Studies Program was a cost share cooperative geothermal exploratory program conducted by DOE and various corporations to investigate geothermal resources primarily in northern Nevada. The data generated by the program inciude the results of geological, geochemical, and geophysical 
surveys. The data sets and accompanying reports represent a basic sulte of data relative to any geothermal investigation and are avallable at a number of locations as noted on the summary sheet.

\section{UURI/ESL Geothermal Sample Library}

Data from Geothermal Resource Assessment programs that have been efther wholly or partially funded by DOE have been collected, catalogued, and stored at the University of Utah Research Institute, Earth Science Laboratory (UURI/ESL). Cuttings and core samples from the Industry Coupled and State Coupled Cooperative Drilling Programs and the User Coupled Conf1rmation Drilling Program have been organized at ESL for use by the public and private sector. The samples represent the most complete set of 11thologic data gathered for federally funded geothermal exploration programs.

The usefulness of the library is limited by the nature of the samples. The samples usually need to be studied at the ESL sample library in Salt Lake City. For special requests, such as sample preparation and analysis, a time element is involved as it becomes necessary to utilize a curator and the services of the geochemical laboratory and staff at ESL. Accessibility to the samples is only through the sample library. Drill cutting samples are often the most useful data gathered from costly drilling programs.

\section{OIT Site Data Base Reports}

The Oregon Institute of Technology (OIT) developed status reports for geothermal development In the states of Alaska, Idaho, Montana, Oregon, Washington, and Wyoming. The reports not only included resource characteristics, but also environmental data that could be used by geothermal developers as an aid to planning and commercialization. State by state institutional analyses are included that address major obstacles to geothermal development. 
The site status reports by OIT represent a basic compilation of physical and institutional factors surrounding all geothermal areas in the particular states. The data are several years old and therefore, the Institutional portions should be used with a degree of caution as legislative and economic factors change over time.

\section{Geotherma1 Leas1ng and Permitting Data Base}

A data file on all separate actions taken by the responsible agencies in Implementing the Geothermal Steam Act of 1970, developed by WAPORA, Inc., was created to provide a mechanism for monttoring the performance of the Federal non-competitive leasing program. The data base is also capable of providing area- or site-specific leasing information on geothermal prospect areas. The project was inftiated to aid in the development of improvements to the Federal geothermal leasing program.

The data base was used to track applications and quantify the timeframes of actions taken by the responsible agencies. The data could be manipulated to provide various table formats and time-lapse distributions of lease applications.

LOGDEX

The LOGDEX data base has been developed by the University of Texas at Austin, Center for Energy Studies (CES) in support of programs sponsored by the U.S. Department of Energy that deal with the assessment of geopressuredgeothermal energy resources. The data base consists of digitized well log Information for several hundred ofl and gas test wells located along the northern Gulf Coast of Texas and Loulstana. A subsidiary data base complled by the CES is comprised of the Geopressured Geothermal Information System Bibllography (GEOBIB), that includes a bibliography and citation extracts of references dealing with geopressured resource and utilization. 


\subsection{Data Base Descriptions}

The following sections present a description of the Individual data bases and include: 1) who complied the data base; 2) where the data base is current1y avallable; 3) the purpose of the data base; 4) a general description of parameters; and 5) references for further information. 


\subsubsection{GEOTHERM}

COMPILED BY: U.S. Department of the Interior, Geological Survey

345 Middlefleld Road, M.S. 984

Menlo Park, CA 94025

AVAILABLE

THROUGH :

U.S. Department of Commerce

National Technical Information Service (NTIS)

Springfield, VA 22161

TECHNJCAL

COORDINATOR(S): James D. B11sS (USGS)

RELEVANT DATES: Date of Release - 1982;

PURPOSE :

The purpose of GEOTHERM is to gather, organize and provide an information data base pertalning to geothermal well, springs, fumaroles, etc. as they may relate to resource characterization.

DESCRIPTION: The GEOTHERM data base contains some 10405 records on magnetic tape. The records give information on resource location, temperature, and fluid geochemistry. Records may contain up to 118 items. Analyses and concentration of condensate, gas and stable isotopes may be present. All numeric fields use the following format: Cy999 where $C=$ qualification code which is always present. Is blank, and 999 is the numeric field for concentration values. Entries include: $L=$ less than, $G=$ greater than, $T=$ trace (not followed by a number),$Q=$ qualified (other data in qualification field), $E$ = estimated, $R=$ midpoint of range (actual range in qualification field). Analytical values for some 55 elements and compounds may be contained within the record, plus analyses of stable 1sotopes of oxygen, sulfur, and carbon. Production flow rates are also Included.

SELECTED

REFERENCES

Bliss, J.D., and Rapport, A., 1983, GEOTHERM: The U.S. Geological Survey Geothermal Information System: Computers and Geosciences, v. 9, no. 1, p. 35-39.

AVAILABILITY :

The GEOTHERM file is avallable on magnetic tape through NTIS at a cost of $\$ 140.00$, NTIS Order No. is PB 84-107705. A hard copy as either paper or microfiche is avallable through the USGS.

KEY WORDS :

Geothermal springs, geothermal wells, fumaroles, geochemistry, temperature, flow rate, stable 1sotopes, geotherm. 
4.4.2 GRAD

COMPILED BY: University of California, Lawrence Berkeley

Laboratory, Englneering and Techntcal Services

Division

Berkeley, California 94720

AVAILABLE

THROUGH :

Lawrence Berkeley Laboratory or,

National Technical Information Service (NTIS)

U.S. Department of Commerce

5285 Port Royal Road

Springfield, VA 22161

TECHNICAL

COORDINATORS: J. Dennfs Lawrence (LBL)

RELEVANT DATES: Inftiated in 1979 as a complement to the computerized "Project Management System" developed by Mitre Corporation. Project was discontinued in 1982 .

PURPOSE: Geotherma1 Resource Areas Data Base (GRAD) was created as part of the the National Geothermal Progress Monitor System in 1979. The data base is organized around the concept of a geothermal area.

DESCRIPTION: The Geothermal Resource Areas Data Base summarlzes the status of exploration and development activities at over 300 resource areas In the United States. GRAD has been organized around the concept of a geothermal resource area, defined as: "An expanse of land associated with a geothermal reservoir that is currently utilized or might be developed in the near future."

Sixteen records have been defined to provide a profile of development activities at each area. Individual facts, (e.g., lease number, well depth, plant name), are grouped together to form the data elements aggregated in each record. The record entry categorles are:

1) Area Description

2) Permitting

3) Leasing

4) Geothermal Wells

5) Exploratory Surveys

6) Resource Evaluations

7) Land Acquisition

8) Environmental Impact
9) Feasibility Studies

10) Financial Negotiations

11) Power Plant

12) Direct Applications

13) Development Issues

14) Laws and Regulations

15) Names and Addresses

16) References 
The GRAD data base was implemented through the SPIRES data management system at Stanford University. Users could enter the data base directly, and through the interactive feature of the system, formulate and generate status reports according to Information needs.

AVAILABILITY: GRAD is currently off-line and is stored on three reels of magnetic tape at Lawrence Berkeley Laboratory. Information has not been added to the database since autumn of 1982 .

In order to obtaln access to the GRAD flle, it would be necessary to bring the file back on-line and access GRAD through the SPIRES system at Stanford University.

SELECTED

REFERENCES :

Yen, Winifred W.S., and Lawrence, Dennis J., 1981, GRAD - A Tool for Program Analysis and Progress Monitoring: Geothermal Resources Counc11 Transactions V. 5, pp. 627-630.

Lawrence, Dennis J., Leung, Ke1th, and Yen, Winifred, 1981, A User's Gulde to the Geothermal Resource Areas Database: Lawrence Berkeley Laboratory Report No. LBL-11492, UC-66a. Prepared for the U.S. Department of Energy under contract No. W-7405-ENG-48, $61 \mathrm{p}$.

KEY WORDS :

Geothermal - Area, - Exploration, - Development, - Leasing, Institutional Analysis, GRAD 
COMPILED BY: Mitre Corporation

McLean, Virginia

AVAILABLE

THROUGH :

National Technical Information Service

U.S. Department of Commerce

5285 Port Royal Road

Springfield, VA 22161

TECHNICAL

Deepak C. Kenkeremath

COORDINATOR: Meridian Corporation

5113 Leesburg Pike, Sulte 700

Fa11s Church, VA 22041

RELEVANT DATES: Concept of the GPM was initlated in 1975. Rationale for a progress monitoring system was developed in 1979 after evaluation of a number of plans. The system was recommended for implementation by a DOE geothermal commerclalization panel in July of 1979. The first report of the GPM was issued in January of 1980 .

PURPOSE :

The GPM is an Information system designed for the Geothermal and Hydropower Technologies Division of the U.S. Department of Energy. The system was developed to 1dentify and quantify trends in the development and use of geothermal energy resources.

DESCRIPTION: The National Geothermal Progress Monitoring System was established by the Department of Energy to support efficlent management of federal geothermal programs and to meet reporting requirements. The Geothermal Progress Monftor supplies information about geothermal development in the United States and the world. The information network set up for the GPM consists of DOE program managers at headquarters plus regional of fices, state resource assessment teams, Industry organizations, national laboratories, and major DOE contractors. Two computerized information systems have been developed as part of the GPM system. These information systems include a Project Management System developed at MITRE Corporation and the Geothermal Resource Area's Data Base (GRAD) developed by Lawrence Berkeley Laboratory. The information reported by the Geothermal Progress Monitoring Systems through the intermittantly published progress report includes: deep drilling and other exploratory activities; summary of leasing; permitting, resource assessments; data releases; legal and Institutional developments; direct use projects; and other activities on a state-by-state basis; technology transfer; and electric power development. 
REFERENCES: Lopez, A.F., Entingh, D.J., and Neham, E.A., 1980, The Geothermal Progress Monttor: Geothermal Resources Council Transactions Vo1. 4, pp. 807-810.

AVAILABILITY: Coples of the Geothermal Progress Monitor are available through the National Technical Information Service. Eight reports had been published by the end of 1983 .

KEY WORDS: Geothermal Energy-information systems; Geothermal Industryinformation systems; Program Management. 


\subsubsection{UURI/ESL Open F1le Data}

COMPILED BY: Earth Science Laboratory

University of Utah Research Institute

391 Chipeta Way, Suite A

Salt Lake City, Utah 84108

AVAILABLE Earth Sclence Laboratory

THROUGH :

TECHNICAL

COORDINATOR(S): Dennis L. Nielson (UURI/ESL)

RELEVANT DATES: DOE 1mplemented program in 1977 for cost shared exploration throughout the Basin and Range Province. Phase I investigated geothermal areas in southwest Utah. Phase II, beginning in 1978, covered a much broader area throughout northern Nevada. Exploration case histories were developed under 18 cost shared contracts. The program was largely completed by 1981 .

PURPOSE: The U.S. Department of Energy's Industry Coupled Case Study program was designed to acquire and disseminate a wide range of exploration data pertalning to geothermal reservoirs in the Basin and Range.

DESCRIPTION: Industry Coupled Program Open File Data consist of results of geochemical, and geophysical surveys as well as both shallow and deep drilling data from some 14 distinct project areas in northern Nevada and southwestern Utah. Included in the Data Set, which are comprised of some 150 separate open file reports, are: Da1ly Drilling Reports; Mud Logs; L1tholog1c Logs; Well Summarles; Thermal Gradient Surveys; Directional Surveys; Down-Hole Electrical and Nuclear Surveys; Surface Electrical, Magnet1c, and Gravity Surveys; Seismic Survey Data; Water and Soll Geochemical Data; Photogeologic and Field Geologic Studies;

SELECTED REFERENCES

Fiore, J.N., 1980, Overview and Status of the U.S. Department of Energy's Industry-Coupled Geothermal Reservolr Assessment Program: Geothermal Resources Counc1l Transactions V.4, pp. 201-204.

AVAILABILITY: Open File Reports are avallable at reproduction costs from the Earth Sclence Laboratory. All materials are avallable for Public Viewing at the following locations:

Marriott Library Special Collections University of Utah Salt Lake City, Utah
U.S. Geological Survey Public Inquiries of fice 125 S. State, Room 8105 Federal Building Salt Lake City, Utah 
AVAILABILITY

(Continued): Nevada Bureau of Mines and Geol. Library, Room 311

Scrugham Engineering Bldg.

U.S. Geological Survey Library

National Center, University of Nevada

12201 Sunrlse Valley Dr.

Reno, Nevada Reston, Virginia

KEY WORDS :

Case Studies, Geothermal Resources, Basin and Range, Industry Coupled Program. 


\subsubsection{UURI/ESL Geothermal Sample Library}

COMPILED BY: Earth Sctence Laboratory

University of Utah Research Institute

391 Chipeta Way, Suite A

Salt Lake C1ty, Utah 84108

AVAILABLE

THROUGH :

Earth Sclence Laboratory

TECHNICAL

COORDINATORS: P.M. Wright (UURI/ESL)

RELEVANT DATES: Late 1970's through early 1980's.

PURPOSE: $\quad$ The Geothermal Sample Library was organtzed as a single location for the collection and cataloguing of geothermal well cuttings and core from DOE funded geothermal drilling projects for use by Individuals, researchers, and government agencles.

DESCRIPTION: The Library, located in Salt Lake City, contains cuttings and core samples from over 190 wells and temperature gradient test holes located in 25 geothermal areas throughout the western U.S. The project areas are:

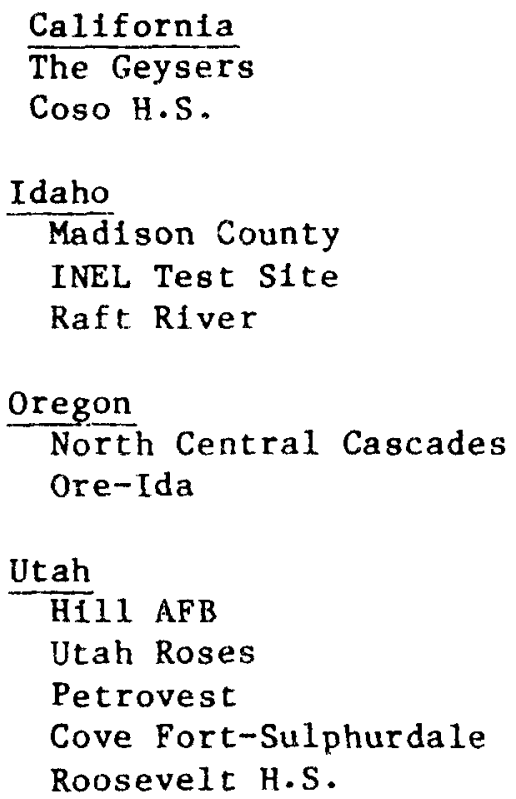

Colorado Pagosa Springs

\section{Nevada}

Baltazor

Tuscarora

San Emid1o

Humbolt House

Colado

Beowawe

Desert Peak

McCoy

Dixie Valley

Stillwater

Soda Lake

SELECTED

REFERENCES :

Universfty of Utah Research Institute/Earth Sclence Lab, 1982, Catalog of the Geothermal Sample Library: Unpublished inventory of core and cuttings samples. 
AVAILABILITY: Samples are available for inspection and analysis by contacting the Earth Scfence Lab for arrangements to visit the 11brary.

KEY WORDS: Geothermal wells, cuttings samples, core samples. 
COMPILED BY: Oregon Institute of Technology

Geo-Heat Utilization Center

Klamath Falls, Oregon 97601

AVAILABLE

THROUGH :

U.S. Department of Commerce

National Technical Information Service (NTIS)

Springfield, VA. 22161

TECHNICAL

COORDINATOR: Paul J. LIenau (OIT)

RELEVANT DATES: Project was inftlated in 1978 in support of DOE's National and Regional Planning and Operations Research. Reporting was completed in 1982 .

PURPOSE: $\quad$ To provide the necessary base information to formulate local, state, federal and private development planning affecting geothermal energy resources in Alaska, Idaho, Montana, Oregon, Washington, and Wyoming.

DESCRIPTION: The OIT Geo-Heat Utilization Center has evaluated the geothermal energy resource development potential of Alaska, Idaho, Montana, Oregon, Washington, and Wyoming. The collective goal of these studfes has been to summarize, for the region, on a site-specific basis the various factors affecting development including resource data base, geological description, reservoir characteristics, environmental characteristics, lease and development status, institutional factors, economics, population and market, and development potential.

SELECTED

REFERENCES :
Bloomquist, R.G., 1979, Geothermal Energy in Washington-Site Data Base and Development Status: OIT Geo-Heat Center Report, prepared in cooperation with Washington Division of Geology and Earth Resources and Washington Energy Office, 192 p.

Brown, Keith E., 1979, Geothermal Energy in Montana-Site Data Base and Development Status: OIT Geo. Heat Center Report, prepared in cooperation with Montana Energy Office, 269 p.

Justus, D., 1979, Geothermal Resources In Oregon-Site Data Base and Development Status: OIT Geo-Heat Center Report, prepared In cooperation with Oregon Energy office, 438 p.

Markle, D., 1979, Geothermal Energy in Alaska - Site Data Base and Development Status: OIT Geo-Heat Center Report, prepared In cooperation with the State of Alaska, Division of Energy and Power Development, 572 p.

McClain, D., 1979, Geothermal Energy in Idaho - Site Data Base and Development Status: OIT Geo-Heat Center Report, prepared in cooperation with the Idaho Energy Office, $465 \mathrm{p}$. 
AVAILABILITY: The OIT Site Data Base Reports are avallable as hard copy reports through NTIS upon ordering. Library coples are available on loan from the Geo-Heat Center Library in Klamath Falls, Oregon.

KEY WORDS: Data Base, Geothermal Energy, Site Specific, Environmental, Geology, Resource Characteristics. 


\subsubsection{Geothermal Leasing and Permitting Data Base}

COMPILED BY: WAPORA, InC.

6900 Wisconsin Avenue

Chevy Chase, MD 20015

AVAILABLE

THROUGH :

National Technical Information Service

U.S. Department of Commerce

5285 Port Roya 1 Road

Springfield, VA 22161

TECHNICAL COORDINATOR:

Gene V. Beeland

Meridian Corporation

5113 Leesburg P1ke

Falls Church, Virginia 22041

RELEVANT

DATES :

Collection of Information was inftlated in 1978 to support the efforts of the Interagency Geothermal Streamlining Task Force, a group organized to develop and recommend remedial changes to geothermal leasing. Results of the Initial program were reported to the Task Force and DOE in a report entftled Statistical Characterization of the Federal Geothermal Leasing and Permitting Program. The preliminary report was printed as an appendix to the Task Force report to the Interagency Geothermal Coordinating Counc11 (IGCC) of January 1979.

PURPOSE: The purpose of the data file is to provide a mechanism for monltoring the performance of the noncompetitive leasing program, and to provide area- or site-specific information on geothermal prospect areas. The needs of the Task Force Included to: 1) track each application through the various steps in the noncompetitive leasing process; 2) quantify the timeframe of each action taken; 3) quantify the length of time for pending applications; and 4) obtain specific insight into Forest Service performance.

DESCRIPTION: The non-competitive data base developed initially has two parts. The first is designed to quantify the timeframes required for processing each application through each step in the leasing system. The second contains information on areas designated by BLM and the Forest Service for application of the environmental assessment requirements of the National Environmental Policy Act of 1969 (NEPA).

The non-competitive data base quantifies: 1) the timeframe required for each action on each application as it moves through the process, and 2) the timeframe from date of application to final disposition. The data can be manipulated to show BLM and Forest Service performance by state, study area, or time period. 
Files are divided into 3 sets. The first set includes step-bystep progress of non-competitive lease applications through the leasing process. Data on all applications processed by the BLY and Forest Service are included from the following states.

\section{GROUP I}

\section{BLM}

Arizona

California

Colorado

Montana

Oregon

Washington

Wyoming

\section{USFS}

Arizona

California

Colorado

Montana

Nevada

New Mexico

Oregon

Washington

Utah

Wyoming.

A random selection of 10 percent of lease application data (due to the volume of applicants for the period ending June, 1978) from the following states are also included in the first file.

\section{GROUP II}

$\begin{array}{lr}\text { BLM } & \underline{\text { USFS }} \\ \text { Idaho } & \text { Idaho } \\ \text { Nevada } & \\ \text { New Mexico } & \\ \text { Utah } & \end{array}$

The second data set includes all actions of the previous offices within all the aforementioned states to June, 1978.

The third data set consists of all information for states contained within Group I to June 1978 and Group II to october 1979.

SELECTED

REFERENCES: Beeland, G.V., Schumann, E., Wieland, M., 1980, Geothermal Leasing and Permitting Data Base - A Tool for Future Planning: U.S. Department of Energy Report DOE/ET/27208-T1, WAPORA, Inc., 50p., Appendices.

AVAILABILITY: The final report, August 22, 1979-December 31, 1980 is available through NTIS.

KEY WORDS: Institutional, Geothermal Leasing, Federal Leasing, Permitting. 
4.4.8 LOGDEX

COMPILED BY: University of Texas at Austin

Center for Energy Studies

Austin, Texas 78712

Phone: (512) 471-4946

AVAILABLE

THROUGH :

Center for Energy Studies: Digitized Well Log Data

National Technical Information Service: Summary Listing

TECHNICAL

COORDINATOR: Robert Schnelder

Center for Energy Studies

RELEVANT

DATES :

Compliation of the data base began in 1977 and has continued through the present. Additions will be made through early 1985 and completion is expected in late 1985, when digitized well log data will be avallable on magnetic tape.

PURPOSE: The LOGDEX data base was developed to serve as a resource base for the many DOE sponsored geopressured geothermal programs along the Texas-Louisiana Gulf Coast. The data base was assembled to complement geosclence research and well $\mathrm{log}$ analysls.

DESCRIPTION: LOGDEX is comprised of data from over 350 wells situated in potentlal geopressured geothermal areas along the northern Gulf Coast. The well logs were obtalned from varlous ofl companies and then digitized to numeric information on magnetic tape.

The overall data base includes a summary listing of well information, an index to well information based upon a classification criteria, and the digitized well logs.

The data components provided in the summary 11sting include:

1) LOGDEX unique 1dentification number; 2) Name of the operator; 3) well name; 4) well location; 5) abstract, track, or block name; 6) API number (1f applicable); and 7) log types avallable.

SELECTED

REPERENCES: H111, T., and Sepehrnoor1, K., 1981, "Summary of LOGDEX Data Base," U.S. Department of Energy Report number DOE/ET/27018-1 Summary, $231 \mathrm{p}$.

H111, T., and Sepehrnoori, K., 1981, "Geopressured Geothermal Bibliography - Volume I (CItation Extracts), and Volume II (Geopressure Thesaurus)," U.S. Department of Energy Report number DOE/ET/27018-1 Vols. I and II. 
AVAILABILITY: The reports containing the summary listing, index, and bibliographic information as listed above are available through NTIS. The digitized log data base $1 \mathrm{~s}$ available only to persons with access to the computer center at the Unfuersity of Texas at Austin.

Application programs have been developed at the CES which makes use of the digftized data. These application programs range from simply plotting the curves avallable for a given $\log$ to analyzing digitized well logs for generating synthetic selsmograms.

Future plans include the continued updating of the data base through early 1985. The CES 1s currently in the process of making the digitized data base available for purchase to private Individuals by late 1985 .

KEY WORDS: Geopressured, Geothermal, Well Logs, Bibliography. 